UNIVERSIDADE DE SÃO PAULO

FACULDADE DE MEDICINA DE RIBEIRÃO PRETO

MESTRADO PROFISSIONAL EM GESTÃO DE ORGANIZAÇÕES DE SAÚDE

FRANCINE DE CASTRO ALVES VICTAL

Impacto emocional de atividade em grupo no acolhimento de acompanhantes de pacientes hospitalizados em situação de emergência

RIBEIRÃO PRETO 


\section{Impacto emocional de atividade em grupo no acolhimento de acompanhantes de pacientes hospitalizados em situação de emergência}

\section{Versão Original}

Dissertação apresentada à Faculdade de Medicina de Ribeirão Preto - FMRP/USP para obtenção do título de Mestre em Ciências.

Área de Concentração: Gestão de Organizações de Saúde

Orientador: Prof. Dr. Carlos Henrique Miranda

RIBEIRÃO PRETO 
Autorizo a reprodução e divulgação total ou parcial deste trabalho, por qualquer meio convencional ou eletrônico, para fins de estudo e pesquisa, desde que citada à fonte.

Ficha catalográfica

Victal, Francine de Castro Alves

Impacto emocional de atividade em grupo no acolhimento de acompanhantes de pacientes hospitalizados em situação de emergência. Ribeirão Preto, 2019.

97 p. : il. ; $30 \mathrm{~cm}$

Dissertação de Mestrado, apresentada à Faculdade de Medicina de Ribeirão Preto/USP. Área de concentração: Gestão de Organizações de Saúde

Orientador: Miranda, Carlos Henrique.

1. Departamento de emergência. 2. Humanização. 3. Termômetro das emoções. 
Nome: Victal, Francine de Castro Alves

Titulo: Impacto emocional de atividade em grupo no acolhimento de acompanhantes de pacientes hospitalizados em situação de emergência

Dissertação apresentada à Faculdade de Medicina de Ribeirão Preto - FMRP/USP para obtenção do título de Mestre em Ciências.

Área de Concentração: Gestão de Organizações de Saúde

Aprovado em:

Banca examinadora

Prof. Dr.

Instituição:

Julgamento:

Prof. Dr.

Instituição:

Julgamento:

Prof. Dr.

Instituição:

Julgamento: 


\section{DEDICATÓRIA}

Aos acompanhantes que aceitaram a participação na pesquisa.

Aos professores, colegas de turma, colaboradores do Mestrado Profissional em Gestão de Organizações de Saúde e especialmente ao

Prof. Carlos como orientador.

À coordenadoria da UE pelas bonitas construções que este trabalho pode trazer.

Á equipe da Sala de Urgência, ao Grupo de Trabalho e Planejamento em Humanização, ao Núcleo Multiprofissional, ambos da Unidade de

Emergência.

Á equipe mutiprofisisonal do Grupo de Acolhimento da Sala de Urgência Aos meus pais, meu irmão Fernando, familiares e amigos. 
AGRADECIMENTOS

Aos meus queridos familiares e amigos, fonte de apoio incondicional.

Ao Prof. Carlos Miranda como orientador pelo zelo e cuidado ao desempenhar seu papel como educador, colaborador e pesquisador.

Ás profissionais, colegas e apoiadoras do Grupo de Acolhimento da Sala de Urgência, representando o Núcleo Multiprofissional da UE

À Luana pela colabração no início, com o piloto nas coletas e pela construção dos cartazes.

Ás amigas e colegas de trabalho Aline, Natália, Jéssica e Raquel pelo auxílio no gerenciamento dos dados através das tabelas e planilhas, além da constante escuta.

À Ana Paula pelo auxílio na montagem dosfluxogramas.

Aos queridos amigos do programa de pós graduação: Alex e Aline.

À Cláudia, secretária do Programa de Pós-Graduação pelo cuidado.

À coordenadoria administrativa da Unidade de Emergência pelo apoio, especialmente ao Dr. Pintyá, por tantos ensinamentos. Por ampliar meus conhecimentos sobre a Gestão em Saúde que mais tarde impulsionaram meu ingressar no mestrado.

E finalmente à Ana Caroline e Carine por todos os grupos de acolhimento coordenados em dias de coleta e por todos os dias, desde o início deste projeto, em que só houve disponibilidade, apoio e interesse em me ajudar. Sem vocês a execução deste projeto não seria possível, muito obrigada! 


\section{RESUMO}

VICTAL, F. C. A. Impacto emocional de atividade em grupo no acolhimento de acompanhantes de pacientes hospitalizados em situação de emergência. 2019. $97 \mathrm{f}$. Dissertação (Mestrado)- Faculdade de Medicina de Ribeirão Preto, Universidade de São Paulo, Ribeirão Preto, 2019.

Introdução: A hospitalização em hospital de emergência geralmente desencadea uma alta tensão emocional nos acompanhantes dos pacientes. Atividades em grupo parece ser uma abordagem adequada para este cenário, pois permite que vários acompanhantes sejam reunidos em uma sala e receberam inúmeras informações a respeito das rotinas da unidade. O objetivo deste investigação foi determinar se uma intervenção através de um grupo de acolhimento a acompanhantes de pacientes hospitalizados em uma sala de urgência poderia reduzir a tensão emocional vivenciada por eles neste cenário. Métodos: Estudo analítico, experimental do tipo intervenção antes e depois. Aplicou-se uma escala analógica conhecida como termômetro das emoções que engloba a avaliação de 5 sentimentos (estresse, ansiedade, depressão, revolta, necessidade de ajuda) variando de 0-10 pontos antes e após uma invervenção em um grupo de acolhimento da sala de urgência. Avaliou-se cada parâmetro isolado assim como a soma dos cinco sentimentos. Através de uma amostra de conveniência, os acompanhantes foram selecionados para participar de um grupo realizado por um profissional da equipe multiprofissional que passou informações previamente padronizadas relacionadas as rotinas da unidade. Considerou-se como uma intervenção efetiva se houvesse um redução $\geq 5$ pontos na escala após a intervenção. Considerou-se com significativo um p- valor $<0,05$. Resultados: Foram incluidos 178 acompanhantes no período de julho de 2018 à abril de 2019 com idade média $47 \pm 15$ anos e predomínio do gênero feminino (74\%). Comparando-se o escore total do termômetro das emoções, observou-se uma redução significativa do escore após a intervenção de 19 pontos (10-30) para 14 pontos (5-26), $\mathrm{p}=0,00001$. Em relação a cada parâmetro isolado, observou-se redução significativa do estresse de 5 pontos (0-8) para 4 pontos (0-6), $\mathrm{p}=0,0002$, da ansiedade de 7 pontos (3-10) para 5 pontos $(2-8), \mathrm{p}=0,00001$, da depressão de 2 pontos $(0-6)$ para 0 pontos (0-4), $\mathrm{p}=0,00001$; da necessidade ajuda de 4 pontos $(0-8)$ para 2 pontos (0-6), $\mathrm{p}=0,00001$. Somente não foi observada redução significativa em relação ao parâmetro de revolta com uma mediana de 0 pontos (0-3) antes da intervenção para 0 pontos (0-3) 
após a intervenção, $\mathrm{p}=0,2385$. A taxa de efetividade desta intervenção foi de $35 \%$. Não foram observadas diferenças estatisticamente significativas em relação as características sociodemográficas e clínicas dos acompanhantes e dos pacientes entre os grupo no qual a intervenção foi efetiva ( $n=62)$ versus o grupo com intervenção inefetiva $(n=116)$.

Conclusão: Intervenção através de um grupo de acolhimento a acompanhantes de pacientes hospitalizados em uma sala de emergência parece ser adequada para redução da tensão emocional desencadeada nos acompanhantes. Este tipo de intervenção apresentou uma taxa de efetividade de $35 \%$. Não foi possível identificar um perfil de acompanhante mais suscetível a este tipo de intervenção.

Palavras-chave: departamento de emergência, humanização, termômetro das emoções. 


\begin{abstract}
VICTAL, F. C. A. Emotional impact of group activity on the reception of caregivers of hospitalized patients in an emergency department 2019. 97 f. Dissertation (Master) Ribeirão Preto Medical School, University of São Paulo, Ribeirão Preto, 2019.
\end{abstract}

Introduction: Hospitalization in an emergency department usually triggers a high emotional tension in patients' caregivers. Group activities seems to be an appropriate approach for this scenario because it allows to give important information about the unit's routine for several caregivers. The aim of this investigation was to determine whether an intervention through a group activity for caregivers of patients hospitalized in an emergency department could reduce the emotional tension experienced by them in this setting. Methods: Analytical, experimental intervention-type study before and after. An analogic scale known as the emotion thermometer was applied, which encompasses the evaluation of 5 feelings (stress, anxiety, depression, anger, need for help) ranging from 0-10 points before and after an intervention in a group activity. Each isolated parameter was evaluated as well as the sum of the five feelings. Through a convenience sample, the caregivers were selected to participate in a group made by a professional of the multidisciplinary team who passed previously standardized information related to the unit's routines. It was considered as an effective intervention if there was a reduction of $\geq 5$ points on the scale after the intervention. A p-value $<0.05$ was considered significant. Results: 178 caregivers were included from July 2018 to April 2019, with a mean age of $47 \pm 15$ years and predominance of females (74\%). Comparing the total emotion thermometer score, a significant reduction in the score after the intervention was observed from 19 points (10-30) to 14 points $(5-26), \mathrm{p}=0.00001$. For each isolated parameter, there was a significant reduction in stress from 5 points $(0-8)$ to 4 points $(0-6), \mathrm{p}=$ 0.0002 , in anxiety from 7 points (3-10) to 5 points.

$(2-8), p=0.00001$, in depression from 2 point $(0-6)$ to 0 points $(0-4), p=0.00001$; in need help from 4 points $(0-8)$ to 2 points $(0-6), p=0.00001$. Only a non significant reduction in relation to the anger parameter was observed from a median of 0 points ( 0 -

3 ) before the intervention to 0 points (0-3) after the intervention, $p=0.2385$. The effectiveness rate of this intervention was $35 \%$. No statistically significant differences were observed regarding the sociodemographic and clinical characteristics of the 
caregivers and patients between the group in which the intervention was effective $(\mathrm{n}=$ $62)$ versus the group with ineffective intervention $(n=116)$.

Conclusion: Intervention through a group activity with caregivers of patients hospitalized in an emergency department seems to be effective in reducing the emotional tension. This type of intervention had an effectiveness rate of $35 \%$. It was not possible to identify a caragivers profile more susceptible to this type of intervention.

Keywords: emergency department, humanization, emotion thermomete. 


\section{LISTA DE TABELAS}

Tabela 1 Característica sociodemografica dos acompanhantes incluídos nesta investigação

Tabela 2 Características sociodemográficas e clínicas dos pacientes incluídos nesta investigação

Tabela 3 Escores obtidos para cada parâmetro do termômetro das emoções isoladamente e para a soma total antes e após a intervenção do grupo de acolhimento da sala de urgência

Tabela 4 Comparação das características dos acompanhantes entre os grupos onde a intervenção foi considerada efetiva versus o grupo onde a mesma foi considerada sem efetividade

Tabela 5 Comparação das características dos pacientes entre os grupos onde a intervenção foi considerada efetiva versus o grupo onde a mesma foi considerada sem efetividade 


\section{LISTA DE GRÁFICOS}

Gráfico 1 Distribuição dos resultados da intervenção

Gráfico 2 Distribuição dos resultados da intervenção - Estresse

Gráfico 3 Distribuição dos resultados da intervenção - Ansiedade

Gráfico 4 Distribuição dos resultados da intervenção - Necessidade de Ajuda

Gráfico 5 Distribuição dos resultados da intervenção - Depressão

Gráfico 6 Distribuição dos resultados da intervenção - Revolta

Gráfico 7 Distribuição dos resultados da intervenção - Total TE 


\section{LISTA DE FIGURAS}

Figura 1 Arco de Marguerez

Figura 2 Fluxograma da seleção amostral

Figura 3 Fluxograma da seleção dos participantes 


\begin{abstract}
ABREVIATURAS
Hospital das Clínicas da Faculdade de Medicina de Ribeirão Preto - HCFMRP

Unidade de Emergência - UE

Sala de Urgência: SU
\end{abstract}

Termômetro das Emoções: TE

Indice de Charlston: ICC

Política Nacional de Humanização - PNH

Grupo de Trabalho - GT

Acute Physiologic and Cronic Health Evaluation - APACHE

SAMU - Serviço de Atendimento Móvel de Urgência

UPA - Unidade de Pronto Atendimento

AVC - Acidente Vascular Cerebral

IAM - Infarto Agudo do Miocárdio

RAS - Redes de Atenção à Saúde

RUE - Rede de Urgência e Emergência 


\section{SUMÁRIO}

$\begin{array}{ll}\text { APRESENTAÇÃO } & 18\end{array}$

$\begin{array}{lr}\text { Preâmbulo } & 19\end{array}$

CAPÍTULO 1 - CONHECENDO A TEMÁTICA 22

CAPÍTULO 2 - EXPERIÊNCIA DO GRUPO DE TRABALHO E 24

PLANEJAMENTO EM HUMANIZAÇÃO DA UE

CAPÍTULO 3 - POLÍTICA DE VISITANTES E ACOMPANHANTES $\mathbf{2 5}$

CAPÍTULO 4 - CONHECENDO O GRUPO DE ACOLHIMENTO DA 26

SALA DE URGÊNCIA

CAPÍTULO 5 - O QUE A LITERATURA TEM A NOS DIZER SOBRE $\mathbf{2 8}$

ACOMPANHANTES?

$\begin{array}{ll}\text { OBJETIVOS } & 31\end{array}$

OBJETIVO GERAL $\quad 31$

OBJETIVO ESPECÍFICO

INTRODUÇÃO

MÉTODOS $\quad 32$

$\begin{array}{ll}\text { LOCAL DO ESTUDO } & \mathbf{3 3}\end{array}$

COLETA DE DADOS

TERMÔMETRO DAS EMOÇÕES

DINÂMICA DE FUNCIONAMENTO DO GRUPO E DA PESQUISA 35

ANÁLISE ESTATÍSTICA

$\begin{array}{ll}\text { RESULTADOS } & 38\end{array}$

CARACTERÍSTICAS DOS ACOMPANHANTES 39

CARACTERÍSTICAS DOS PACIENTES

A TENSÃO EMOCIONAL DOS ACOMPANHANTES $\mathbf{4 2}$

INTERVENÇÃO EFETIVA VERSUS INTERVENÇÃO NÃO 49

EFETIVA

DISCUSSÃO

CONCLUSÃO

REFERÊNCIA $\quad 56$

APÊNDICES E ANEXOS 
"O lugar natural da doença é o lugar da natural da vida - a família: doçura dos cuidados espontâneos, testemunho do afeto, desejo comum da cura, tudo entra em cumplicidade para ajudar a natureza que luta contra o mal (...)", (FOUCALT, 2008, p.19). 


\section{APRESENTAÇÃO}

Ao iniciar a escrita desta dissertação compreendi a complexidade deste projeto no conjunto de ações que têm cercado minha vida profissional nos últimos 10 anos. Foram muitos espaços de troca e de aprendizado. Destaco o HC Campus, o Cebes, o Conselho Municipal de Saúde, a Escola Nacional de Saúde Pública Sergio Arouca - ENSP da Fiocruz e a Unidade de Emergência, a UE.

A UE aconteceu na minha vida. Sua sabedoria, seu dinamismo, seu time. Fui conhecendo seus espaços e me conhecendo nestes espaços.

Em 2017, lembro de ter defendido a permanência dos acompanhantes em uma reunião do Grupo de Trabalho da Sala de Urgência - (GT da SU) mas ainda sem saber como resolveríamos os conflitos que se instalavam com a permanência dos acompanhantes.

Recordo-me depois, de ter utilizado ensinamentos da humanização e da educação permanente para problematizar e criar estratégias para criação do grupo de acolhimento junto da equipe multiprofissional.

Parte das estratégias desse grupo consistiram em utilizar cartazes explicativos sobre a rotina hospitalar. Cartazes estes, que foram confeccionados pela Luana, minha estagiária, por mim e por todo o serviço de Terapia Ocupacional, minha encantadora área de formação profissional.

Entendo que não teria feito tantas contribuições se não estivesse à frente da coordenação do Grupo de Trabalho e Humanização da Unidade de Emergência desde que lá cheguei. Foram tantos aprendizados.

De lá pra cá somam-se 11 grupos de acolhimento na instituição dedicado aos acompanhantes. De lá pra cá os espaços da gestão foram crescendo em mim tanto quanto eu neles. De lá pra cá comecei a me interessar ainda mais por compreender os cuidados despendidos aos acompanhantes.

Hoje, ao final desta pesquisa, estarei compartilhando os resultados das emoções dos acompanhantes mensuradas durante a intervenção do grupo de acolhimento multiprofissional da Sala de Urgência.

Espera-se que a pesquisa possa provocar reflexões acerca destas metodologias a serem desenvolvidas na Gestão em Saúde. 


\section{PREÂMBULO}

A Unidade de Emergência do Hospital das Clínicas da Faculdade de Medicina de Ribeirão Preto - UE - HCFMRP -USP existe há mais de 60 anos e caracteriza-se por ser um serviço público hospitalar de urgência referenciada que realiza atendimentos de urgência e emergência em nível terciário (alta complexidade) à população da Regional de Saúde XIII do Estado de São Paulo.

Não é incomum cenas de pronto socorros superlotados pelo Brasil nos noticiários, um desafio para seus gestores. Recentemente, seguindo a lógica de sucesso norte-americana que manteve "ER - Emergency Room" por 19 anos no ar a indústria televisiva brasileira criou um série semelhante, "Sob Pressão" que chega a sua terceira temporada trazendo situações de um hospital com porta de entrada de emergências no Rio de Janeiro.

As fragilidades expostas no seriado tem como pano de fundo as questões que permeiam o Sistema Único de Saúde (SUS) e a gestão de um serviço de emergência em nosso país.

Desta forma, entende-se que o hospitais responsáveis pelo atendimento à emergência carregam consigo uma árdua missão, o constante aprimoramento da gestão, uma vez que, neste cenário, usuários, acompanhantes, trabalhadores e gestores estão expostos numa dinâmica onde sempre a procura por leitos hospitalares é maior do que a oferta disponível.

A Gestão em Saúde é tão antiga quanto a Saúde Pública sendo os hospitais as instituições que foram se aprimorando em planejamento em saúde no Brasil, se aproximando da economia e da administração de empresas. Discute-se a partir destas questões democratizar a gestão, superando as restrições das teorias administrativas e ampliando a discussão da gestão participativa e co-gestão (CAMPOS; CAMPOS, 2008).

As perspectivas da gestão compartilhada foram amplamente discutidas pelo médico sanitarista e atual presidente da Associação Brasileira de Saúde Coletiva, Gastão Wagner na concepção de Paidécia, reflexão acerca dos mecanismos que componham a da relação profissional/usuário no cenário contemporâneo (CAMPOS; AMARAL, 2007).

Descata-se nesta lógica a necessidade de envolvimento entre usuários e trabalhadores em um processo de reforma e de reorganização, uma vez que, propor mudanças organizacionais é mais eficaz se os sujeitos envolvidos também mudem (CAMPOS; AMARAL, 2007). 
Paralelo a construção de metodologias que possibilitem sujeitos envolvidos, a gestão em saúde se encarrega também do planejamento, criando ferramentas que possibilitem soluções para gerir.

O planejamento no SUS é um das ações gestoras que além de requisito legal, são as garantias da unicidade e dos princípios constitucionais do SUS, sendo o ato de planejar uma exigência com conhecimento técnico, que ocorrerá por meio de instrumentos e ferramentas desenvolvidas em processos de trabalho (BRASIL, 2016).

No Brasl, entre as correntes do planejamento em saúde, destaca-se a gestão estratégica do Laboratório de Planejamento (LAPA) da Faculdade de Medicina de Campinas; a corrente do Planejamento Estratégico Comunicativo, representado por núcleos do Departamento de Administração e Planejamento de Saúde (DAPS) da Ensp/Fiocruz; a corrente da Vigilância à Saúde; e a escola da Ação Programática da Faculdade de Medicina da USP (MEHRY, 1995; RIVIERA; ARTMANN, 2010).

Destaca-se de fundamental importância os mecanismos de gestão para os hospitais universitários, já que espera-se um modelo de administração hospitalar dada a proposição da Portaria $n^{\circ}$. 1000/2004, como um dos requisitos obrigatórios para certificação de ensino. Entende-se o planejamento estratégico como uma ferramenta bastante efetiva e um dos pilares da administração hospitalar (ASSIS, 2017; BRASIL, 2014).

O planejamento estratégico caracteriza-se por ser um processo contínuo que envolve tomada de decisões de modo a organizar sistematicamente as atividades que serão necessárias para que a mesma aconteça. É uma maneira de medir o resultado de ações e decisões tomadas sendo, essenciais para às organizações no alcance dos s objetivos. O planejamento estratégico foi e é amplamente utilizado na administração pública com bons resultados, já que, através do instrumento a administração pode definir prioridades para execução de suas ações (GONÇALVES el al., 2018).

A partir destes conceitos dialogados, observa-se que a UE há alguns anos tem investido em metodologias de gestão compartilhada através dos grupos de trabalho, espaços onde diferentes atores da assistência e da gestão possam analisar e melhor definir as estratégias gestoras a serem utilizadas.

Os hospitais são instituições complexas e não é incomum na literatura questões que envolvam sua hegemonia e autonomia nos modelos de gestão, ainda que, vários estudos dialoguem sobre problemas de hospitais do SUS na eficácia e eficiência na gestão dos mesmos (CAMPOS; AMARAL, 2007). 
A co-gestão, a gestão participativa é um desafio para constituir espaços coletivos, construir espaços em que as pessoas pensam e decidam. Espaço também de apoio e indissociabilidade já que, o SUS preconiza a participação social, a ideia de incluir usuários e trabalhadores na gestão (CAMPOS, 2005).

A gestão participativa é uma das diretrizes da PNH (2003) e propõe a construção de um trabalho em equipe, por meio de colegiados em que possa ser possível o diálogo, planejamento e execução de ações para determinado equipamento de saúde (BRASIL, 2009)

Entre as ferramentas utilizadas para a sistematização e acompanhamento deste processo está o Planejamento Estratégico definido para o HCFMRP a cada quatro anos e contemplando objetivos e metas a serem alcançadas por eixos.

Como compreende-se esta pesquisa como um retrato de parte das ações desenvolvidas na UE, das quais associadas aos desdobramentos propostos pela gestão participativa, bem como, ao objetivo estratégico relacionado à Humanização previsto no Planejamento Estratégico 21052018 para UE optamos por apresentar estes dados nos seguintes capítulos:

No Capítulo 1: "Conhecendo a Temática", será discutido os serviços de urgência e emergência e as contrubuições da Política Nacional de Humanização.

O Capítulo 2: "Experiência do Grupo de Trabalho e Planejamento em Humanização da UE" trará um breve panorama das construções propostas durante 2016 e 2017 com base no Planejamento Estratégico.

Um das ações vislumbradas pelo Grupo de Trabalho e Planejamento em Humanização da UE envolveriam diretamente a presença dos acompanhantes, que foi discutido em vários Grupos de Trabalho, entre estes o da Sala de Urgência, que adotou como uma das estratégias a construção de um grupo, que será descrito, no Capítulo 3: "Conhecendo o Grupo de Acolhimento da Sala de Urgência".

Entendendo a necessidade de criar uma normativa que pudesse melhor organizar a presença dos acompanhantes, a coordenadora administrativa da UE construiu uma "Política de Acompanhantes e Visitantes da UE”, que será apresentada no Capítulo 4.

Por fim, no Capítulo 5 "O que a literatura tem a nos ensinar sobre acompanhantes?” tem por objetivo apresentar uma reflexão acerca dos estudos envolvendo acompanhantes no contexto hospitalar; bem como, ofertar subsídios para estratégias como grupos e possivelmente mensurar tais intervenções através das emoções experimentadas. 


\section{CAPÍTULO 1 CONHECENDO A TEMÁTICA}

Dentre as muitas questões propostas pelo Sistema Único de Saúde (SUS) está a assistência dividida por níveis de complexidade contendo equipamentos e ofertas assistenciais compatíveis às necessidades em saúde apresentadas pelos usuários de seus serviços.

Segundo Ribas (2006) o hospital é compreendido como um ponto de referência nos sistemas de saúde e detém um papel fundamental nos serviços, já que, é neste espaço que se concentram as maiores diversidades de bens e de serviços e a maior densidade tecnológica; por isso, é pensado como o equipamento de saúde mais capacitado a ofertar assistência às doenças graves.

A Portaria GMM S 1600 de 07 de julho de 2011 implanta a Rede de Urgência e Emergência (RUE) nas Redes Regionais de Atenção à Saúde (RRAS). Através da RUE propõese ofertar um acolhimento com classificação de risco de forma ágil e oportuna visando qualificar o acesso humanizado e integral aos usuários que se encontrem em situação de urgência/emergência (BRASIL, 2011).

Propõe-se ainda, que a rede RUE possua diferentes componentes e interfaces como: a prevenção e a promoção, a atenção primária, o SAMU - 192, as enfermarias de retaguarda e cuidados intensivos, a atenção domiciliar, portas hospitalares de atenção à urgências - SOS Emergência e inovações tecnológicas de linha de cuidado prioritária como o Acidente Vascular Cerebral (AVC), o Infarto Agudo do Miocárdio e Traumas (NOMURA, 2013).

As portas de entrada hospitalares de urgência e emergência são entendidas como "serviços instalados em uma unidade hospitalar para prestar atendimento ininterrupto ao conjunto de demandas espontâneas e referenciadas de urgências clínicas, pediátricas, cirúrgicas e/ou traumatológicas, obstétricas e de saúde mental.” (BRASIL, 2013, p. 45).

De acordo com o manual instrutivo da RUE do Ministério da Saúde (2013) a compreensão de quão qualificado encontra-se os serviços ofertados nestes espaços hospitalares pressupõe a manutenção e ou aperfeiçoamento dos seguintes critérios: protocolos de classificação de risco, protocolos clínico-assistenciais e procedimentos administrativos no hospital; articulação entre os serviços (SAMU E UPAS) a fim de construir fluxos coerentes e efetivos de referência e contrarreferência; equipe multiprofissional compatível às necessidades da porta de entrada da urgência bem como, sua integração e investimento à nível de capacitação - educação permanente; garantias de leitos de retaguarda e contrareferência, 
além, da implantação de ferramentas da gestão da clínica, a qual primordialmente preconiza a qualificação do cuidado.

Neste sentido, considerando a necessidade que qualificação da prática assistencial nestes serviços hospitalares de emergência algumas questões se apresentam: como construir o cuidado em saúde mediante um quadro de adoecimento agudo, grave e tantas vezes instável? Como é a compreensão das informações recebidas pelo usuário que encontra-se adoecido? Como ocorre a comunicação entre a equipe de saúde e os que se utilizam dos serviços? Como é o entendimento dos acompanhantes que vivenciam estes quadros de saúde instáveis ao acompanhar seus entes?

Dal Pai e Lauret (2005) ressaltam que estes espaços conotam muitas vezes "um verdadeiro espelho da situação de miséria da sociedade brasileira”, pois neste cenário encontraremos “(...)baleados, suicidas, violentados, politraumatizados”. É um espaço imprevisível e de "ritmo acelerado de trabalho, a vigilância constante, a sobrecarga física e a busca incessante pela manutenção da vida", logo neste sentido instala-se às mesmas questões destacadas pelas autoras: "seria possível pensar em assistência humanizada no âmbito emergencial?" (DAL PAI; LAURET, 2005, p.232).

A Política Nacional de Humanização (PNH), lançada em 2003 propõe uma tentativa de se colocar em prática os princípios do SUS no cotidiano dos serviços de saúde, a fim de gerar mudanças nos modos de gerir e cuidar (BRASIL, 2013).

Humanizar pode ser entendido como a inclusão de processos de cuidado e de gestão. Passa a ser, desta forma, uma oferta de atendimento de qualidade em que possam ser articulados espaços de avanços tecnológicos com acolhimento, além de ambientes de cuidado melhores para usuários, acompanhantes e profissionais de saúde (BRASIL, 2004; BRASIL, 2013).

Nos serviços de urgência e emergência, a PNH (2004), p.14 propõe:

\footnotetext{
"1.Acolher a demanda por meio de critérios de avaliação de risco, garantindo o acesso referenciado aos demais níveis de assistência.

2.Comprometer-se com a referência e a contra-referência, aumentando a resolução da urgência e emergência, provendo o acesso à estrutura hospitalar e a transferência segura, conforme a necessidade dos usuários.

3.Definir protocolos clínicos, garantindo a eliminação de intervenções desnecessárias e respeitando as diferenças e as necessidades do sujeito."
}

Para Bonfá (2014) o acolhimento compreendido como dispositivo de humanização propõe a criação de espaços de práticas de atenção, as quais possibilitem constituir questões 
como a realização da escuta qualificada das demandas dos usuários e acompanhantes, o que possibilitaria compreender a importância de suas necessidades e assim, estabelecer uma possibilidade de comunicação efetiva.

Campos destaca que, a Humanização no SUS depende de um constante aperfeiçoamento da Gestão Compartilhada, estratégias que visem o aumento do poder do doente e valorize a presença dos acompanhantes a fim de otimizar mudanças nas estrtuturas, nos processos de trabalho e também nas pessoas.

\section{CAPÍTULO 2 \\ EXPERIÊNCIA DO GRUPO DE TRABALHO E PLANEJAMENTO EM HUMANIZAÇÃO DA UE}

Como previamente mencionado a UE em consonância com as condições previstas pela ferramenta de co-gestão têm trabalhado com Grupos de Trabalho e Planejamento na unidade. Fóruns estes que, diferentes atores edificam construções colaborando com a gestão da unidade.

Entre estes grupos, o Grupo de Trabalho e Planejamento em Humanização (GTPHUE) surge oficiamente em novembro de 2015 ainda que, diferentes iniciativas já haviam sido direcionadas para a humanização da UE.

De acordo com reunião realizada em 10 de dezembro de 2015, o Conselho Deliberativo do HCFMRP-USP, aprovou, por unanimidade, o Planejamento Estratégico para o período 2015-2018. Entre as ações planejadas para a categoria urgência e emergência encontrava-se a premissa: criar um núcleo de humanização.

Sendo assim, adotou-se como objetivo estratégico a revisão de processos de trabalho e a criação de novos processos. Com este objetivo espera-se viabilizar um fluxo de trabalho ordenado que pudesse ser executado de forma simples e segura.

O GTPHUE realizou-se desta forma, um conjunto de atividades a fim de possibilitar a criação e implantação de um núcleo através da formação do próprio grupo e da aproximação com o Coletivo de Hospitais e Santas Casas do Departamento Regional de Saúde XIII; estas ações foram determinantes para o alcance das metas propostas no objetivo estratégico.

A condução das ações realizadas foram descritas estão compilados em um relatório do planejamento estratégico (ANEXO 1). 
Cerca de um ano depois, as ações do grupo foram mapeadas e organizadas conforme as diretrizes da humanização a fim de vislumbrar o alcance das construções e gerar reflexões e delinear as estratégias de trabalho do grupo.

A partir dos arquivos apresentados, nota-se que o GTPHUE destacou em inúmeros momentos questões amplamente destacadas no decorrer destes capítulos e que uma das atividades proposta foi a construção de um projeto do acompanhante na SU, sendo proposto como ação o desenvolvimento de um grupo multiprofissional de orientações aos acompanhantes. O mesmo, será apresentado no capítulo a seguir.

\section{CAPÍTULO 3}

\section{POLÍTICA DE VISITANTES E ACOMPANHANTES}

De acordo com o Ministerio da Saúde (2007) a visita aberta e o direito ao acompanhante é uma proposta da PNH (2003) que tem como premissa manter o projeto de vida do usuário, de modo a garantir o acesso de sua rede de suporte social as unidades de internação (BRASIL, 2007).

O acompanhante é um "representante da rede social da pessoa internada que o acompanha durante toda sua permanência nos ambientes de assistência à saúde" (BRASIL, 2007, p.3).

A presença do acompanhante, que muitas vezes é representado por um familiar está em consonância com a diretriz da clínica ampliada, que sugere o conhecimento acerca da história e dos contextos daqueles que adoecem.

A Clínica Ampliada está intimamente relacionada à humanização das práticas em saúde, já que, o termo "ampliada" associa-se à uma abordagem que propõe acessar a historia de vida dos sujeitos, a fim de garantir a integralidade do cuidado, portanto, a idéia de uma proposta ligada a singularização; quem são estes sujeitos, como será este encontro clínico e quais condutas terapêuticas serão tomadas.

Para assistir a esses usuários, compreendendo seu protagonismo e participação é preciso contornar as dificuldades, em especial, de compreensão destes da amplitude e da singularidade do sofrimento experimentado; além, do alto grau de imprevisibilidade dos acontecimentos vivenciados no processos de saúde-doença, de cura e de morte (RIBAS, 2006).

Os acompanhantes são entendidos como fundamentais na compreensão desta amplitude de singularidades já que os sujeitos adoecidos fazem parte de um sistema e es que 
o acompanham, também. Através da presença, possibilita-se mais garantias de segurança e confiança; o que gera um cuidado mais efetivo (BRASIL, 2007).

Possuem o direito ao acompanhante menores 18 anos (art. 12 da Lei 8069/90 - Estatuto da Criança e do Adolescente), idosos - 60 anos ou mais (art. 16 da Lei 10741/03 - Estatuto do Idoso) e partunientes através da Lei $\mathrm{n}^{\mathrm{o}} 11.108 / 05$ durante o trabalho de parto e pós parto (BRASIL, 1990; BRASIL, 2003; BRASIL, 2005).

Já compreendendo os benefícios da presença dos acompanhantes, a UE tem aprimorado os processos e ampliado a presença dos mesmos para aqueles que não são assegurados pela lei. Inicialmente a presença dos acompanhante para a população adulta não gestante foi implantada na Sala de Urgência.

Visando ofertar subsídios para a presença dos visitantes e acompanhantes a coordenadoria da UE escreveu uma política para visitantes e acompanhantes, o que é mais um norteador dos fundamentamentos para o trabalho com os acompanhantes.

\section{CAPÍTULO 4}

\section{CONHECENDO O GRUPO DE ACOLHIMENTO DA SALA DE URGÊNCIA}

Este grupo surge dentro de um espaço de construção coletiva, o GT da SU, que quinzenalmente se reuni para dialogar sobre as questões que envolvem os processos de trabalho deste espaço físico.

O fórum de discussões da SU é o GT mais antigo da UE. Nos arquivos deste grupo é possível afirmar que os diálogos que envolviam a presença e os direitos dos acompanhantes e a gestão do acolhimento sempre foram uma preocupação dos trabalhadores e dos gestores. Especialmente de assistentes sociais e psicólogas que compõem as categorias não médicas também mais antigas da unidade na assistência ofertada à SU.

No entanto, a ideia ganhou forças em 2017 e passou a ser construída pela equipe multiprofissional da SU juntamente com apoio de outros grupos como GTPHUE e o Grupo de Trabalho em Educação Permanente da UE - GTPEP

Foi de fundamental importância nesta construção os aprendizados teórico práticos ofertado pelo GTPEP, uma vez que, a Política Nacional de Educação Permanente em Saúde (PNEPS) destaca a importância da discussão dos problemas vivenciados a partir da observação da realidade (BRASIL, 2009).

O Grupo de Acolhimento da Sala de Urgência foi uma construção coletiva e multiprofisssional, foi o desfecho de uma sequência de ações: observação da realidade, lista de 
problemas, fundamentos teóricos e finalmente as possibilidade de solucioná-los, o grupo aparece como uma hipótese de solução como previsto na metodologia do Arco de Marguerez, esquematizado na figura 1 (PRADO; et al. 2012).

Figura1: Arco de Marguerez

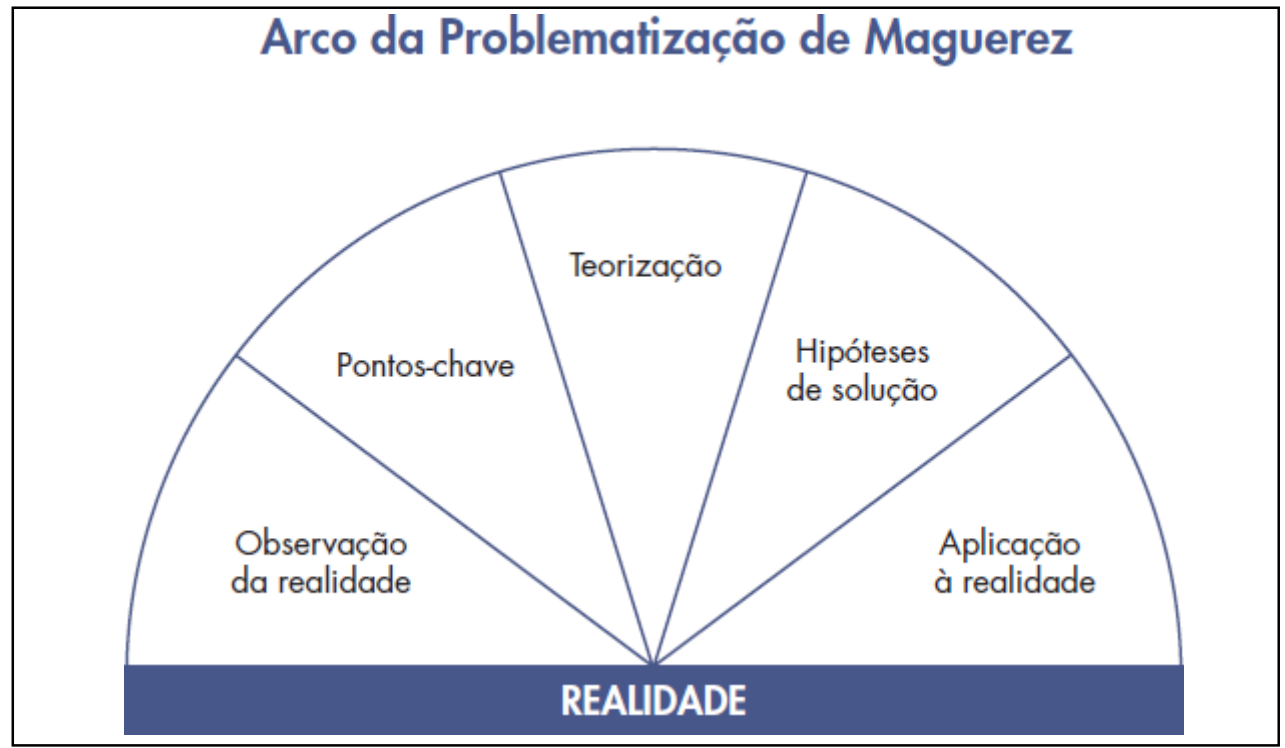

Fonte: UNA-SUS/UFSC

A aplicação à realidade, foi iniciada através das execuções dos grupos sendo este processo de trabalho descrito na construção deste grupo sendo desde 2018 chamado: Grupo de orientações aos acompanhantes da sala de urgência que encontra-se no APÊNDICE A.

Tendo em vista o grande número de acompanhantes na sala de urgência, a abordagem individual de cada acompanhante seria impraticável. Deste modo, dentro deste grupo de trabalho surgiu a idéia de se criar um grupo multiprofissional que pudesse se reunir com os acompanhantes em uma sala reservada da unidade de emergência com uma certa periodicidade e transmitir informações padronizadas a respeito da rotina de funcionamento da sala de urgência.

As informações eram diretamente relacionadas ao atendimento do paciente desde a sua chegada até o momento da alta e continham: informações gerais sobre a UE, rotina da SU, principais questões vivenciadas pelo paciente na chegada como jejum e medicações, papel dos profissionais na SU, como e quando conversar com o médico, papel do acompanhante, horários das refeições, horário de visitas, informações sobre transferências e alta hospitalar e canais de comunicação como a pesquisa de satisfação do usuário e o serviço de ouvidoria. 
Entendendo que o processo de assimilação do conteúdo seria mais efetivo se utilizássemos imagens didáticas foram confeccionados para esta atividade cartazes contendo as informações centrais desta atividade (APÊNDICE B).

A periodicidade do grupo foi sendo testada e mantem-se há mais de um ano sendo realizado 3 vezes por semana. Em cada dia da semana há uma categoria responsável com um profissional designado através de escala para o desenvolvimento das ações daquele dia.

O grupo conta com as seguintes categorias profissionais: enfermagem, fisioterapia, nutrição, psicologia, serviço social e terapia ocupacional. Sendo coordenado pela psicologia, serviço social e terapia ocupacional.

As ações são discutidas trimestralmente para acompanhamento dos resultados, bem como, melhorias no processo de trabalho.

\section{CAPÍtULO 5}

\section{O QUE A LITERATURA TEM A NOS DIZER SOBRE ACOMPANHANTES?}

Pesquisadores de Almada em Portugal realizaram recentemente estudo investigativo a fim de identificar junto aos profissionais de enfermagem considerações acerca da presença do familiar em situações de emergência; além do apoio ao doente devido ao vínculo, estão entre as vantagens da presença destes acompanhantes a possibilidade de fornecer informações clínicas aos profissionais (BATISTA; et al., 2017).

No mundo, pesquisas como a desenvolvida por profissionais da enfermagem na Universidade de Léon, na Espanha, já apontavam em seu desfecho para a necessidade de modificarmos a infraestrutura e a organização do serviço hospitalar de emergência de modo a ofertar uma sala propícia para realização de acolhimento e orientação à acompanhantes (FERRERAS GONZÁLEZ, 2017).

Nas pesquisas brasileiras que analisam o cotidiano nos serviços de urgência/emergência também se discute como estratégia a criação de propostas que possibilitem uma reestruturação organizacional destes espaços; uma vez que, através destes estudos, espera-se também, viabilizar melhorias na qualidade das ofertas de atendimentos prestados e garantir novos subsídios para um campo de conhecimento ainda pouco explorado em nível nacional (FEIJÓ; CORDONI JUNIOR; SOUZA, 2015).

Sanches (2013) salienta que a presença do acompanhante em âmbito hospitalar representa um campo fértil para estudos, como este que propomos, já que refletir acerca do 
papel destes acompanhantes que muitas vezes são familiares, objetivam o aprimoramento do cuidado, podendo viabilizar melhorias assistenciais.

Segundo estudo randomizado desenvolvido por pesquisadores da Universidade de Washington em 2015 à familiares de enfermos das Unidades de Terapia Intensiva em cuidado de fim de vida, ficou evidente que após intervenção usando de ferramentas informativas, a comunicação se apresentou como facilitadora e capaz de reduzir taxas de depressão em familiares; o estudo comprovou inclusive redução em tempo de permanência hospitalar associado à intervenção, em especial nos que foram a óbito (CURTTIS et al. 2015).

Pinho e Kantorki (2006) propuseram-se a descrever as inquietações dos familiares de três usuários de uma Unidade de Emergência de uma cidade do Estado do Rio Grande do Sul.

Entre as questões levantadas, os autores destacam que os familiares esperam dos profissionais de saúde: "o lado humano do atendimento, com vistas à minimização do sofrimento psíquico, está no olhar, na palavra adequada, na escuta, no abraço zeloso", fato este que conota "a priorização do conhecimento técnico-científico que fundamenta a prática rotinizada e compartimentalizada nessas unidades" (PINHO; KANTORSKI, 2006, p. 230).

Os grupos tem se apresentado como uma estratégia vantajosa no auxílio à estes acolhimentos, destaca-se muitas experiência na Atenção Primária ainda em Sala de Espera com usuários e seus acompanhantes, especialmente quando se envolve a espera da consulta, dos procedimentos, do diagnóstico, das mudanças de setores, entres outros.

Para além da temática das salas de espera na Atenção Primária, estratégias semelhantes a discutida do grupo da SU tem sido desenvolvidas nos hospitais brasileiros; visando, acolher, aproximar o acompanhante do processo saúde-doença de modo colaborativo, informá-los sobre os direitos e deveres de usuários do SUS e a apresentação de normas e rotinas institucionais estão entre os objetivos previstos (BATISTA, 2009; FRANÇA 2014).

Guardadas as semelhanças, os grupos mencionados diferenciam-se nos contextos, já que foram idealizados para enfermarias em hospital geral. Na situações de emergência as emoções tendem a estar mais exacerbadas tanto quanto a criticidade dos casos, o que segundo Neinkotter (2011) exigirá um processo crítico-reflexivo.

A pesquisadora menciona entre os resultados encontrados em sua pesquisa desenvolvida na Emergência de um hospital escola na regão sul do país, os acompanhantes relevam três itens que consideram positivo: poder acompanhar durante a internação, receber informações e profissionais com postura acolhedora (NEINKOTTER, 2011). 
E o que contemplaria uma postura acolhedora? Que emoções experimenta-se para interpretar estas ações? Inúmeros estudiosos do ramos da psicologia consideram que as emoções são o eixo central da vivencia humana (DIAS; CRUZ; FONSECA, 2008).

Ao compreender que ocupam esse espaço na vida humana e que muitas sensações podem ser experimentadas na emergência, medo, ansiedade, angústia, tristeza, revolta, tensão, desgaste físico e emocional; como saber se são efetivas as ações de acolhimento nas emergências? Como compreender se as estratégias adotadas para promover o acolhimento aos acompanhantes gera impacto em suas emoções?

Entende-se que os espaços de grupo podem auxiliar nos processos educativos e de troca de experiências comuns entre as partes, possibilitando a interação do conhecimento popular com os saberes dos profissionais de saúde em uma relação de cuidado.

Os grupos podem funcionar como "terreno fértil", sendo um território onde ocorrem estas trocas um cenário dinâmico composto muitas vezes por vários atores. Sendo assim, a nossa hipótese de trabalho é que a intervenção através dos grupos de acompanhantes da sala de urgência pode reduzir a tensão emocional observada nestes indivíduos. 


\section{OBJETIVOS}

\subsection{OBJETIVO GERAL}

Avaliar o impacto da intervenção em grupo de acolhimento na tensão emocional dos acompanhantes de pacientes hospitalizados na sala de emergência de um hospital terciário.

\subsection{OBJETIVOS ESPECÍFICOS}

$\checkmark$ Caracterizar o perfil sócio-demográfico dos acompanhantes da sala de urgência.

$\checkmark$ Avaliar a eficácia da intervenção em grupo

$\checkmark$ Tentar identificar perfis de acompanhantes mais responsivos a esta intervenção. 


\section{INTRODUÇÃO}

A hospitalização em um hospital de emergência geralmente desencadea uma alta tensão emocional nos seus acompanhantes. Contudo, devido ao grande volume de usuários e acompanhantes neste ambiente, uma abordagem individualizada de cada acompanhante pela equipe multiprofissional é impraticável.

Os trabalhos em grupo parece ser um tipo abordagem adequada para este cenário, onde vários acompanhantes podem ser reunidos em uma sala e inúmeras informações a respeito das rotinas da unidade podem ser ofertadas para estes indivíduos. Contudo, pelo nosso conhecimento, nenhuma investigação científica avaliou o impacto deste tipo de intervenção na tensão emocional vivenciada pelo acompanhante durante internação de um conhecido em uma sala de emergência.

A nossa hipótese é que a intervenção através de um grupo de acolhimento a acompanhantes de pacientes hospitalizados em uma sala de urgência poderia reduzir a tensão emocional vivenciada por eles neste cenário.

\section{MÉTODOS}

Estudo analítico, experimental, pareado, do tipo antes e depois de uma intervenção que inclui acompanhantes de pacientes hospitalizados na sala de urgência da Unidade de Emergência do Hospital das Clínicas da Faculdade de Medicina de Ribeirão Preto da Universidade de São Paulo.

Através de uma amostragem por conveniência foram incluídos os acompanhantes aleatoriamente convidados a participar do grupo de acolhimento ao acompanhante da sala de urgência sendo que o mesmo deveria ter idade $\geq 18$ anos e o paciente deveria estar internado por pelo menos 12 horas neste local. Foram excluídos os acompanhantes analfabetos e que não concordaram em participar da pesquisa através da assinatura de termo de consentimento livre e esclarecido.

O presente estudo teve seu projeto submetido para análise no Comitê de Ética em Pesquisa do HC- FMRP-USP, sendo aprovado, bem como, o Termo de Consentimento Livre e Esclarecido, disponível no APÊNDICE C. O mesmo encontra-se de acordo com o Processo HCRP n4981/2017, conforme ofício n 1541/2017 (ANEXO 2). 


\section{LOCAL DO ESTUDO}

O trabalho em grupo foi realizado em uma sala localizada na recepção central da Unidade de Emergência do HC-FMRP-USP conhecida como "sala da família" em um dos períodos de segunda a sexta-feira pela manhã entre as 9 e 11 horas. A Unidade de Emergência do HC-FMRP-USP é um hospital dedicado exclusivamente ao atendimento de emergência com cerca de 3000 atendimentos/mês sendo referência terciária de alta complexidade para 25 municípios constituientes da DRS-XIII. A sala de urgência da UEFMRP-USP é constituída por 27 leitos destinados ao atendimento inicial por equipes das grandes áreas (clínica médica, neurologia, cirurgia geral, ortopedia e ginecologia). Assim como outros pronto-atendimentos de emergência apresenta uma taxa de ocupação elevada, sendo que na maior parte do tempo encontra-se acima de sua capacidade máxima em torno de $150 \%$.

\section{COLETA DE DADOS}

Para realização da pesquisa optou-se pela utilização de um instrumento padronizado, sendo que o acompanhante recebia um formulário que continha informações sociodemográficas básicas como idade, sexo, grau de parentesco, escolaridade, profissão e nome do paciente (APÊNDICE D). Em seguida os acompanhantes que concordaram em participar da pesquisa recebiam um formulário que continha o Termômetro das Emoções, cujo maior detalhamento será feito na sequência. Era explicado aos acompanhantes como executar o preenchimento deste termômetro, os mesmos tinham um prazo de cinco minutos para o preenchimento do mesmo, o qual era recolhido após o término deste tempo.

As informação demográficas e clínicas do pacientes hospitalizados referentes aos acompanhantes participantes do grupo de acolhimento da sala de urgência foram obtidas atráves de revisão de prontuário médico. Para avaliação da gravidade aguda de cada paciente foi optado por realização de um escore prognóstico, neste caso o APACHE IIAcute Physiology and Chronic Health Evalution. O Cálculo do APACHE II foi realizado online através do endereço eletrônico da APACHE II Scoring System Calculator Medscape Reference sendo o editor em idioma Português. Para avaliação do número de comorbidades crônicas de cada paciente foi optado por realizar o Índice de comorbidade de Charlson. 
O grupo era conduzido conforme as orientações padronizadas entre os membros da equipe multiprofissional e apresentava uma duração de cerca de 30 minutos. Após o término do grupo, um novo formulário contendo o termômetro era entregue ao acompanhante que tinha que preenche-lo novamente em um prazo de cinco minutos sem ter acesso ao primeiro questionário respondido.

\section{TERMÔMETRO DAS EMOÇÕES}

Pesquisadores do ramo da oncologia clínica, frequentemente se deparavam com a necessidade de avaliar condições estressantes à que os portadores de câncer estavam submetidos. Neste contexto foi desenvolvido um instrumento por vários profissionais em 1997 com intuito de propor um método para quantificar as alterações emocionais nos pacientes em cuidados oncológicos.

O instrumento passou por validações em inúmeros países haja vista sua grande contribuição e auxílio no tratamento de pacientes oncológicos. No Brasil, a validação foi realizada por uma psicooncologista da Universidade de Brasília em 2009 - " $\underline{\text { Termômetro }}$ de distress: validação de um instrumento breve para avaliação diagnóstica de pacientes oncológicos" (DECAT; ARAÚJO, 2008).

Poucas publicações foram encontradas na literatura brasileira desde então, sendo todas voltadas para o público específico oncológico, em contrapartida, a versão em língua portuguesa validada em Portugal

foi amplamente divulgada (DECAT; LAROS; ARAÚJO, 2009).

Em 2010, a escala Termômetro das Emoções (TE) foi validada em Portugal por Pereira, Teixeira \& Figueiredo - Universidade do Minho, 2010, adaptado da versão original Distress Thermometer, NCCN, Alex Mitchell.

Estudo desenvolvido por Dias e Velho (2014) em Portugal resolveu testá-lo em população diferente, evidenciando que o instrumento é sensível para pacientes com acne. Através do mesmo foi possivel avaliar o impacto psicossocial da acne.

Trata-se de uma escala que visa mensurar sintomas de estresse, ansiedade, depressão, revolta e necessidade de ajuda utilizando uma escala analógica visual com respostas que variam de 0 ("nenhuma emoção") a 10 ("máximo daquela emoção"), com maiores pontuações indicando, portanto, maior intensidade daquela emoção. Para este estudo considerou-se cada emoção isoladamente, assim como, a somatório destes cinco itens que poderiam variar de 0-50 pontos (ANEXO 3) 
Para melhor entendimento, disponibilizou-se um TE realizado por um dos participantes da pesquisa. Sendo o primeiro aplicado antes da intevenção e o segundo após a intervenção (ANEXO 4).

\section{DINÂMICA DE FUNCIONAMENTO DO GRUPO E DA PESQUISA}

As categorias profissionais que desenvolvem o grupo realizam, nos dias de intervenção as seguintes ações:

1. Checa-se o número de internações na $\mathrm{SU}$ e o número de acompanhantes;

2. Seleciona os locais que contenham acompanhantes;

3. Realiza convite individual por acompanhante para participação do grupo;

4. Direciona os acompanhantes à sala da família

5. Realiza intervenção em grupo

6. Direciona os acompanhantes ao seu local de origem

A pesquisadora entrava na sala antes de iniciar o grupo e fazia o convite à participação da pesquisa explicando o objetivo da mesma através da leitura do Termo de Consentimento Livre e Esclarecido (APÊNDICE C). Aqueles que aceitavam a participação recebiam uma folha contendo o Termômetro das Emoções e uma caneta. Com os papeis em mãos a pesquisadora explicava os 5 termômetros e solicitava que tentassem quantificar o quanto (0 à 10) estavam sentido de cada emoção.. Quando todos terminavam a pesquisadora solicitava que o participantes escrevesse o nome próprio no termômetro e recolhia as avaliações.

Ao deixar a sala, um dos integrantes da equipe multiprofissional que conduziria o grupo entrava na sala e iniciava a intervenção. No entanto, ao terminar, nos dias em que havia aplicação do Termômetro das Emoções a profissional do grupo solicitava que os acompanhantes aguardassem para realizar a segunda etapa da pesquisa.

Após finalizada a intervenção em grupo a pesquisadora retornava a sala da familia e redistribuia novos Termômetros das Emoções solicitando que preenchessem novamente.

A intervenção apresentava uma duração aproximada de 30 à 50 minutos e não era realizada pela pesquisadora, mas por um dos profissionais da equipe multiprofissional escalado, devidadamente treinado e que se utilizava de cartazes informativos contendo as principais informações da rotina da SU, bem como, os direitos e deveres dos acompanhantes (APÊNDICE B). 
A ação se inicia com a apresentação da profissional que solicita a apresentação dos membros do grupo. A profissional informa que está naquele momento representando todos os profissionais da SU com intuito de informá-los sobre o funcionamento da SU.

Inicia as informações pelo tipo de hospital que é a UE e o atendimento fornecido. Orienta sobre a chegada, a classificação de risco, o que é preciso ser feito para realizar as investigações diagnósticas reforçando a imprtância do jejum. Aos poucos vais introduzindo novos elementos como a medicação, a rotina dos banhos, o horário que as equipes médicas se comunicam com as famílias, o apoio multiprofissional, até chegar nas condições de alta hospitalar.

O desenvolvimento dos cartazes foi construído idealizando que cada informação pudesse vir de modo sequencial, da entrada à saída, de modo que, o que é previsto que ocorra na internação seja mencionado, esclarecido e orientado.

À todo momento é permitido que o acompanhante possa falar, esclarecer dúvidas, perguntar ou mesmo se ausentar da ação de modo a assegurar que os mesmos estejam à vontade para esclarecer dúvidas.

\section{ANÁLISE ESTATÍSTICA}

Para determinação do tamanho amostral, como não se encontrou na literatura científica a aplicação do termomêtro das emoções em uma amostra semelhante optou-se por realizar a aplicação do mesmo em um projeto piloto consituído por 17 acompanhantes de pacientes da sala de urgência. Sendo que estes pacientes não foram incluídos na análise final. Encontrou-se uma média de 20 pontos com um desvio-padrão de 15 neste grupo. Considerou-se na análise ad hoc que uma intervenção efetiva através do grupo de acolhimento da sala de urgência causaria uma redução de 5 pontos no escore total do termômetro das emoções. Considerando-se um nível de significância de 5\% e um poder de $80 \%$ estimou-se ser necessária a inclusão de 143 acompanhantes nesta amostra. Criouse um fluxograma para demonstração do tamanho amostral (Figura 2). 
Figura 2 - Determinação do tamanho amostral

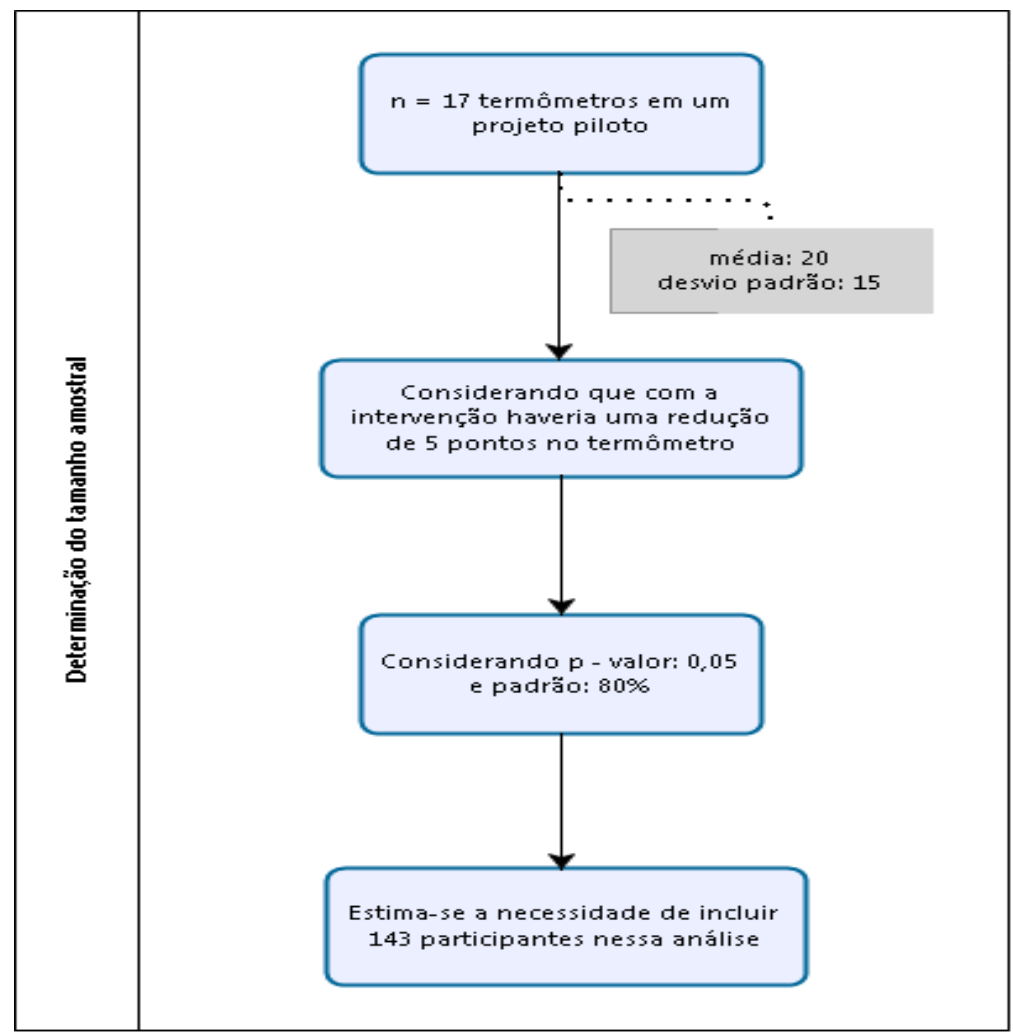

Fonte: Elaboração própria

Para se avaliar o tipo de distribuição das variáveis foi utilizado o teste de Shapiro - Wilk. As variáveis categóricas foram expressas em frequência e porcentagem As variáveis contínuas com distribuição normal foram expressas em média \pm desvio padrão. As variáveis não compatíveis com a distribuição normal foram expressas em mediana e intervalo interquartil (IQR). Para comparação entre duas ou mais variáveis categóricas utilizou-se o teste do qui-quadrado. Para comparação entre duas variáveis contínuas não pareadas com distribuição normal utilizou-se o teste t de Student. Para comparação entre duas variáveis contínuas não pareadas e sem distribuição normal foi utilizado o teste de Mann- Whitney. Para comparação entre duas variáveis contínuas pareadas sem distribuição normal utilizou-se do teste de Wilcoxon. Considerou-se como significativo um p-valor bicaudal $<0,05$. O software estatístico Stata 13.1 (College Station; TX; USA) foi utilizado para análise estatística e construção dos gráficos. 


\section{RESULTADOS}

No período de julho de 2018 à abril de 2019 foram realizados 60 grupos de acolhimento aos acompanhantes na sala de urgência, em 33 destes grupos foi realizada a avaliação proposta por esta investigação. .Durante este período que estes grupos ocorreram havia 1533 usuários recebendo atendimento na sala de urgência da Unidade de Emergência do HC-FMRP-USP. Destes pacientes, 758 estavam com acompanhantes no período de execução dos 60 grupos. Destes 758 acompanhantes registrados, 311 participaram dos 60 grupos realizados nestes dez meses e 199 acompanhantes foram recrutados para participar desta investigação entre 311 acompanhantes que estavam na sala de urgência durante a execução dos 33 grupos onde foi realizada esta intervenção.

Entre os 199 acompanhantes, somente 12 não aceitaram participar da pesquisa e nove participantes foram excluídos por não completarem todas as etapas, gerando questionários incompletos. Sendo assim, foram incluídos 178 acompanhantes nesta investigação. O Fluxograma apresentado na Figura 3

Figura 3: Fluxograma da inclusão de participantes no estudo

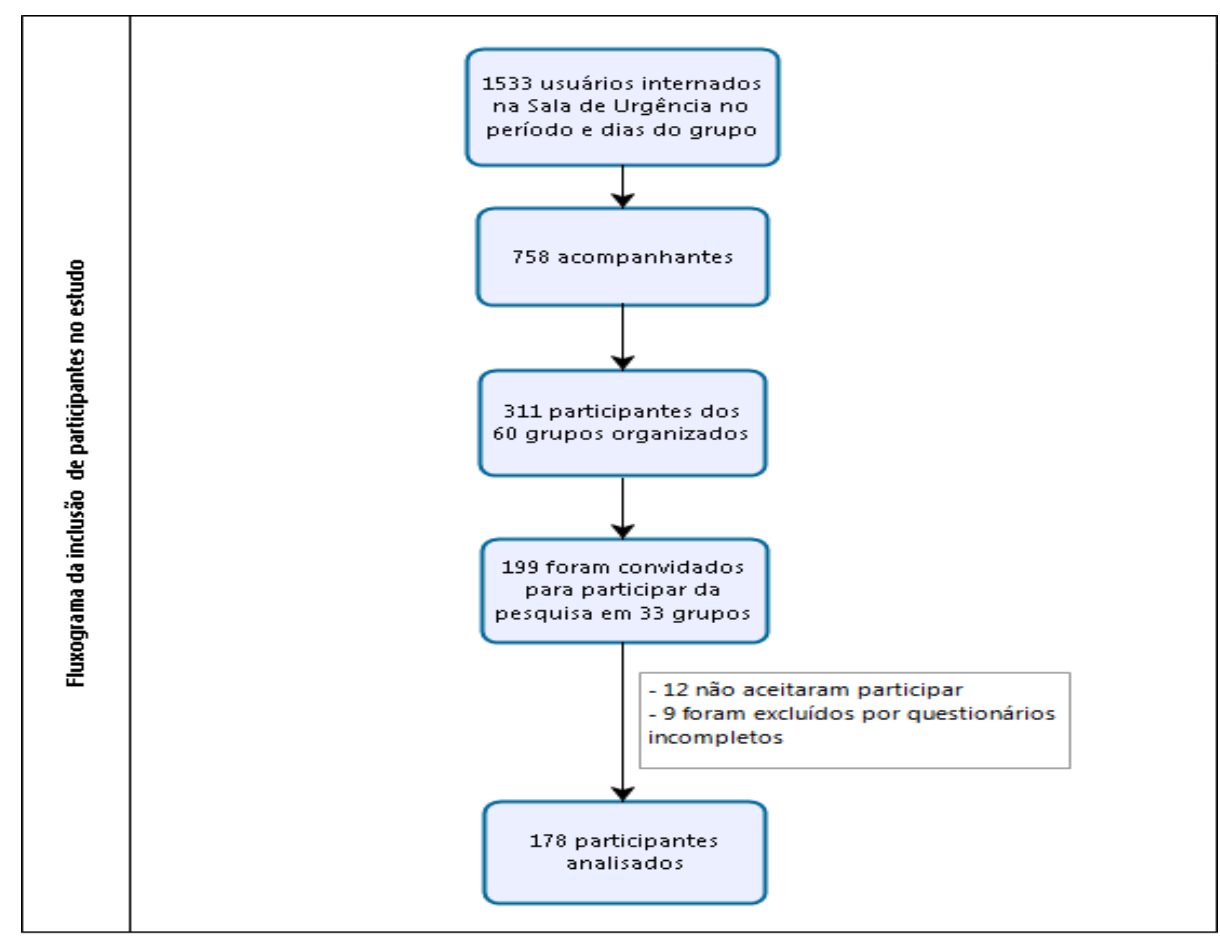

Fonte: Elaboração própria 


\section{CARACTERÍSTICAS DOS ACOMPANHANTES}

Entre 178 acompanhantes participantes, a maioria encontra-se na fase adulta,com uma idade média de $47 \pm 15$ anos e predominantemente do gênero feminino que correspondeu a, $74 \%$ da amostra.

Em relação ao grau de parentesco dos acompanhantes, cônjuges (33\%) e filhos (26\%) representaram mais da metade da amostra e em relação a escolaridade apresentada foi intermediária, sendo que predominou os acompanhantes com ensino médio incompleto (34\%) seguido pelo ensino fundamental incompleto (22\%).

Entre as condições associadas a ocupação dos acompanhates destaca-se os serviços gerais (28\%) seguido pela categoria outros $(21 \%)$. Vale a pena resaltar a elevada prevalência de desempregado $(18 \%)$ e do lar $(12 \%)$.

As características sociodemográficas dos acompanhantes são mostradas na Tabela 1.

\section{CARACTERÍSTICAS DOS PACIENTES}

As características sociodemográficas e clínicas dos pacientes hospitalizados referentes aos acompanhantes incluídos na investigação são mostrados na tabela 2 . Observou-se, uma predominância de idosos, com a faixa etária predominante entre 6080 anos, responsável por $44 \%$ da amostra e com distribuição equilibrada entre os gêneros.

A maioria dos pacientes estava sob cuidados da clínica médica (52\%), seguidos pela cirurgia (14\%) e neurologia (14\%). Houve uma alta diversidade de diagnósticos expresso pelo predomínio da categoria outros (64\%), sendo que a presença de neoplasia foi responsável por $17 \%$ das internações.A taxa de mortalidade intra-hospitalar observada foi de $05 \%$ com uma duração da internação com uma mediana de 3,5 dias (2- 6 dias). $\mathrm{O}$ escore APACHE apresentou uma mediana de 9 pontos (5-13 pontos) e o índice de Charlson apresentou uma mediana de 1 ponto (0-3 pontos). A duração da internação na sala de urgência apresentou uma mediana de 69 horas (28-114 horas). 
Tabela 1. Característica sócio demográfica dos acompanhantes incluídos nesta investigação

\begin{tabular}{|c|c|}
\hline Características & $\mathrm{N}=178$ \\
\hline Idade; anos média \pm dp & $47 \pm 15$ \\
\hline \multicolumn{2}{|l|}{ Sexo; n $(\%)$} \\
\hline Feminino & $131(74 \%)$ \\
\hline Masculino & $47(26 \%)$ \\
\hline \multicolumn{2}{|l|}{ Grau de parentesco; n (\%) } \\
\hline Esposo (a) & $59(33 \%)$ \\
\hline Filho (a) & $46(26 \%)$ \\
\hline Mãe & $18(10 \%)$ \\
\hline Irmão (a) & $15(8 \%)$ \\
\hline Outros & $40(23 \%)$ \\
\hline \multicolumn{2}{|l|}{ Escolaridade; n (\%) } \\
\hline Médio incompleto & $60(34 \%)$ \\
\hline Fundamental incompleto & $39(22 \%)$ \\
\hline Fundamental completo & $31(17 \%)$ \\
\hline Superior incompleto & $24(13,5 \%)$ \\
\hline Outros & $24(13,5 \%)$ \\
\hline \multicolumn{2}{|l|}{ Ocupação; n (\%) } \\
\hline Serviços gerais & $49(28 \%)$ \\
\hline Desempregado (a) & $32(18 \%)$ \\
\hline Do lar & $21(12 \%)$ \\
\hline Aposentado (a) & $19(11 \%)$ \\
\hline Autônomo & $17(10 \%)$ \\
\hline Outros & $40(21 \%)$ \\
\hline
\end{tabular}

Fonte: Elaboração própria

Nota: $( \pm d p)$ : desvio padrão; $n(\%)$ : porcentagem 
Tabela 2. Características sóciodemográfica e clínicas dos pacientes incluídos nesta investigação

\begin{tabular}{|c|c|}
\hline Características & $\mathrm{N}=178$ \\
\hline \multicolumn{2}{|l|}{ Idade (anos); $\mathrm{n}(\%)$} \\
\hline $17-25$ & $19(11 \%)$ \\
\hline $25-40$ & $21(12 \%)$ \\
\hline $40-60$ & $40(22 \%)$ \\
\hline $60-80$ & $78(44 \%)$ \\
\hline$>80$ & $20(11 \%)$ \\
\hline \multicolumn{2}{|l|}{ Sexo; n $(\%)$} \\
\hline Masculino & $92(52 \%)$ \\
\hline \multicolumn{2}{|l|}{ Especialidade de Atendimento; n (\%) } \\
\hline Clínica Médica & $92(52 \%)$ \\
\hline Cirurgia & $43(24 \%)$ \\
\hline Neurologia & $25(14 \%)$ \\
\hline Outros & $18(10 \%)$ \\
\hline \multicolumn{2}{|l|}{ Diagnóstico principal; n (\%) } \\
\hline Câncer & $30(17 \%)$ \\
\hline Infecção & $15(8 \%)$ \\
\hline AVC & $10(6 \%)$ \\
\hline Síndrome Coronariana & $9(5 \%)$ \\
\hline Outros & $114(64 \%)$ \\
\hline Mortalidade; n (\%) & $9(5 \%)$ \\
\hline Duração internação em dias; mediana (IQR) & $3,5(2-6)$ \\
\hline Duração internação SU, horas; mediana (IQR) & $69(28-114)$ \\
\hline Índice Charlson; mediana (IQR) & $1(0-3)$ \\
\hline Índice Charlson corrigido pela idade; mediana (IQR) & $2(0-3)$ \\
\hline APACHE II; mediana (IQR) & $9(5-13)$ \\
\hline
\end{tabular}

Fonte: Elaboração própria

Nota: n(\%): porcentagem; (IQR): intervalo interquartil 


\section{A TENSÃO EMOCIONAL DOS ACOMPANHANTES}

Comparando-se o escore total do termômetro das emoções observou-se uma redução significativa do escore após a intervenção de 19 pontos (10-30) para 14 pontos (5-26), p=0,00001. Em relação a cada parâmetro constituinte do termômetro das emoções observou-se redução significativa do estresse de 5 pontos (0-8) para 4 pontos (0-6), $\mathrm{p}=0,0002$, da ansiedade de 7 pontos (3-10) para 5 pontos (2-8), p=0,00001, da depressão de 2 pontos (0-6) para 0 pontos (0-4), $\mathrm{p}=0,00001$; da necessidade ajuda de 4 pontos (0-8) para 2 pontos $(0-6), \mathrm{p}=0,00001$. Somente não foi observada uma redução significativa em relação ao parâmetro de revolta com uma mediana de 0 pontos (0-3) antes da intervenção para 0 pontos (0-3) após a intervenção, $\mathrm{p}=0,2385$.

Na tabela 3 são apresentadas as pontuações isoladas e o escore total obtido no termômetro das emoções antes e após as intervenções. Os gráficos 2, 3, 4, 5, 6 e 7 também ilustram estes resultados comparando o antes e o depois da intervenção do grupo de acolhimento da sala de urgência.

Tabela 3. Escores obtidos para cada parâmetro do termômetro das emoções isoladamente e para a soma total antes e após a intervenção do grupo de acolhimento da sala de urgência.

\begin{tabular}{lccc}
\hline \multicolumn{1}{c}{ Emoções } & Antes & Depois & $\mathrm{P}$ \\
\hline Estresse; mediana (IQR) & $5(0-8)$ & $4(0-6)$ & 0,0002 \\
Ansiedade; mediana (IQR) & $7(3-10)$ & $5(2-8)$ & 0,00001 \\
Depressão; mediana (IQR) & $2(0-6)$ & $0(0-4)$ & 0,00001 \\
Revolta; mediana (IQR) & $0(0-3)$ & $0(0-3)$ & 0,2385 \\
Necessidade de ajuda; mediana (IQR) & $4(0-8)$ & $2(0-6)$ & 0,00001 \\
Soma total; mediana (IQR) & $19(10-30)$ & $14(5-26)$ & 0,00001 \\
\hline
\end{tabular}

Fonte: Elaboração própria

Nota: (IQR): intervalo interquartil

Conforme foi determinado na metodologia considerou-se na análise ad hoc que a intervenção seria considerada efetiva se houve uma redução $>=5$ pontos do escore soma total. Levando em conta esta definição, observou-se que a intervenção do grupo dacolhimento da sala de urgência foi efetiva em 62 acompanhantes (35\%). 
Gráfico 1: Distribuição dos resultados da intervenção

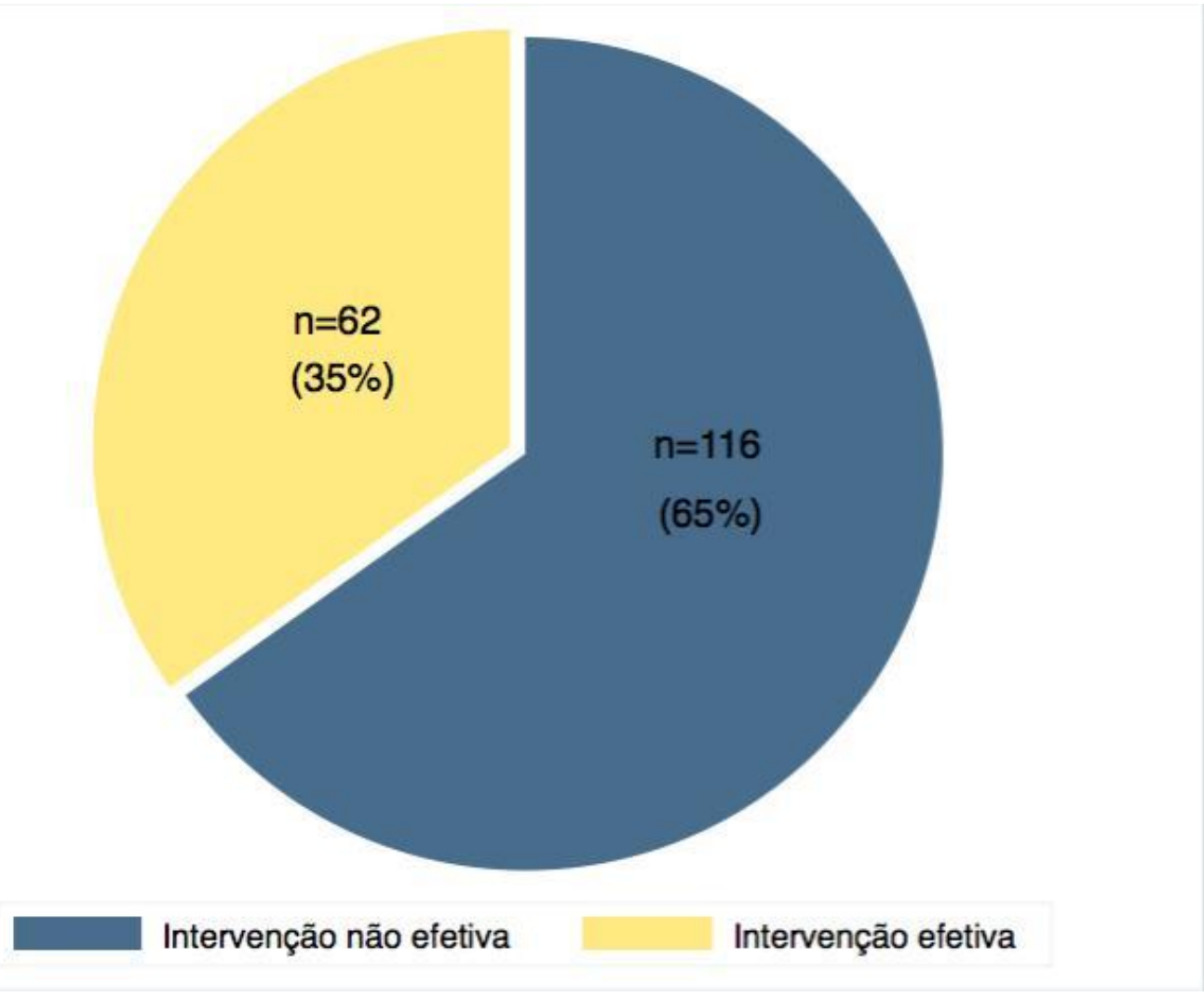

Fonte: Elaboração própria

Nota: Gráfico circular mostrando a porcentagem das intervenções do grupo de acolhimento da sala de urgência que foram consideradas como efetivas. 
Gráfico 2: Distribuição dos resultados da intervenção - Estresse

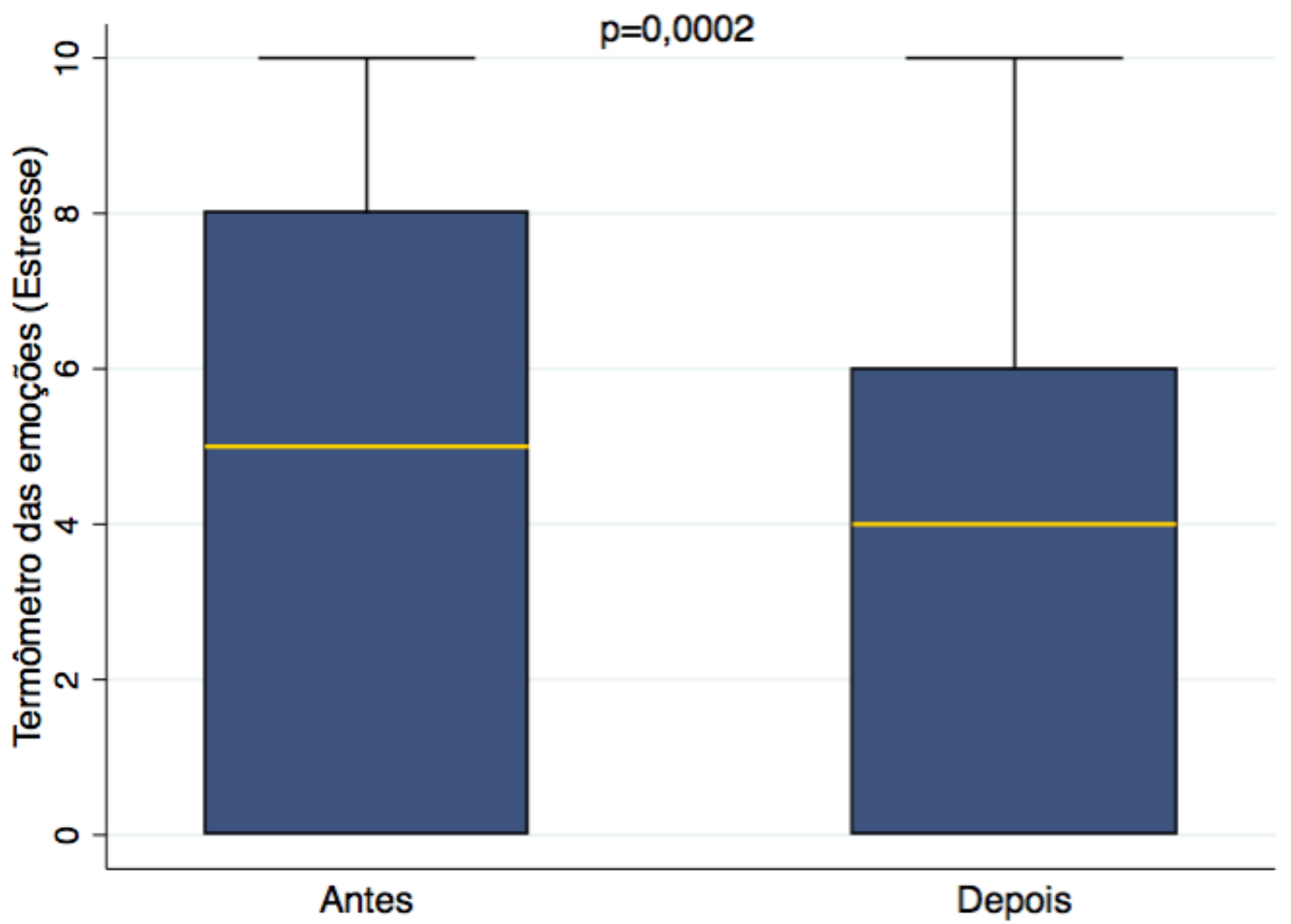

Fonte: Elaboração própria

Nota: Gráfico do tipo box plot mostrando a evolução do parâmetro de estresse do termômetro das emoções antes e após a intervenção do grupo de acolhimento da sala de urgência. A linha horizontal amarela representa a mediana, as barras azuis representam os percentis P25 e P75 e as linhas horizontais pretas representam os percentis P10 e P90. 
Gráfico 3: Distribuição dos resultados da intervenção - Ansiedade

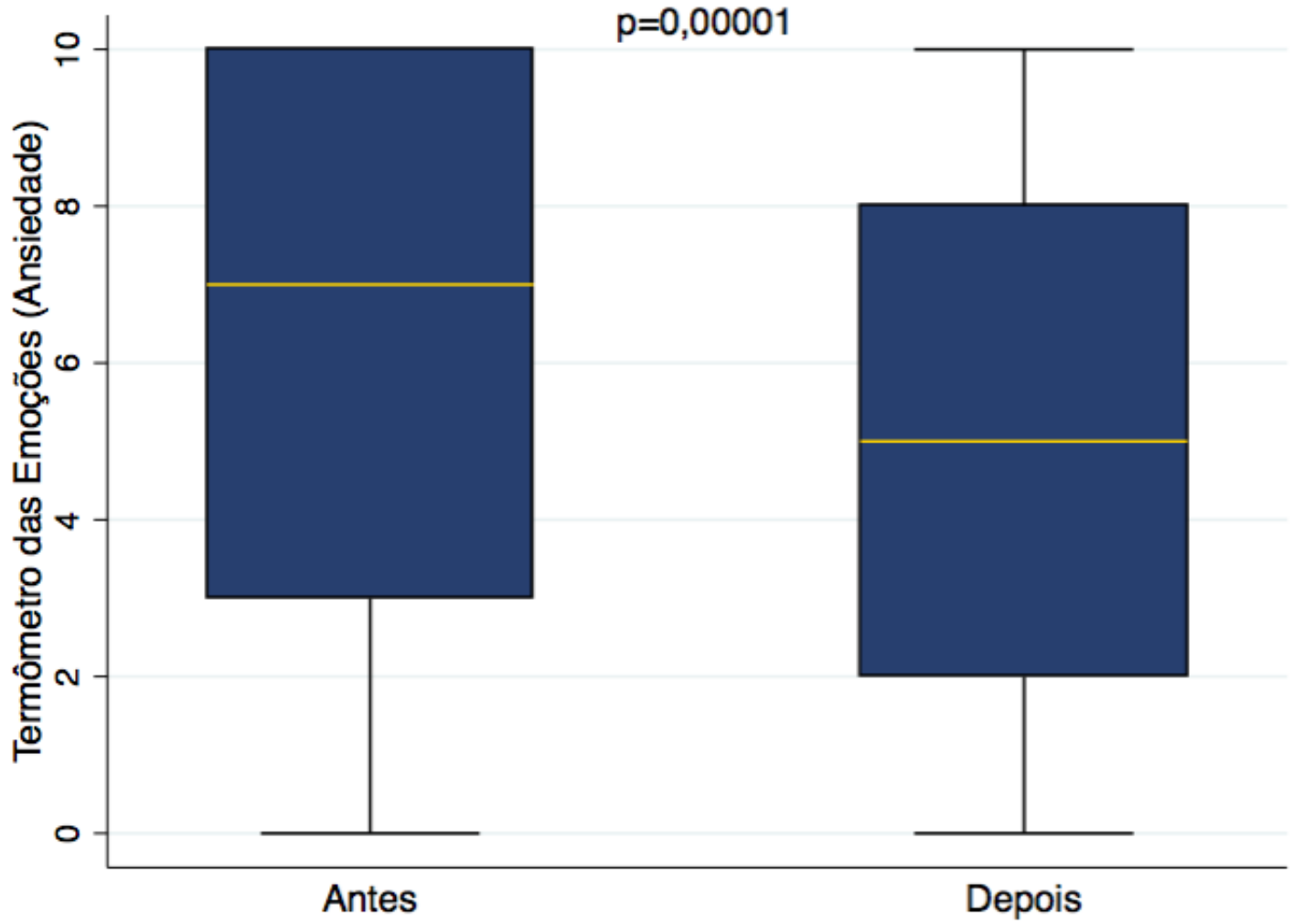

Fonte: Elaboração própria

Nota: Gráfico do tipo box plot mostrando a evolução do parâmetro de ansiedade do termômetro das emoções antes e após a intervenção do grupo de acolhimento da sala de urgência. A linha horizontal amarela representa a mediana, as barras azuis representam os percentis P25 e P75 e as linhas horizontais pretas representam os percentis P10 e P90. 
Gráfico 4: Distribuição dos resultados da intervenção - Necessidade de Ajuda

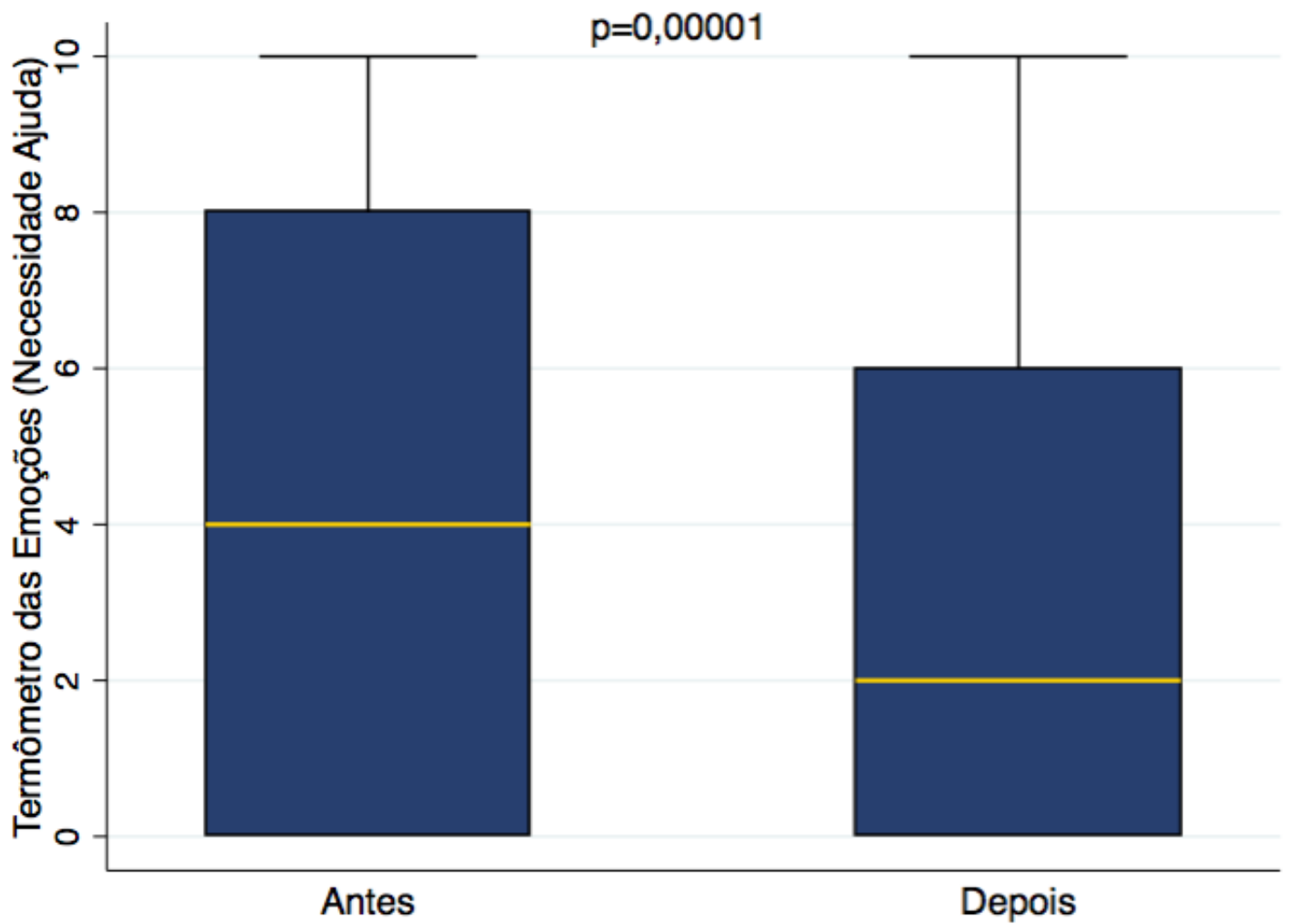

Fonte: Elaboração própria

Gráfico 4. Gráfico do tipo box plot mostrando a evolução do parâmetro de necessidade de ajuda do termômetro das emoções antes e após a intervenção do grupo de acolhimento da sala de urgência. A linha horizontal amarela representa a mediana, as barras azuis representam os percentis P25 e P75 e as linhas horizontais pretas representam os percentis P10 e P90. 
Gráfico 5: Distribuição dos resultados da intervenção - Depressão

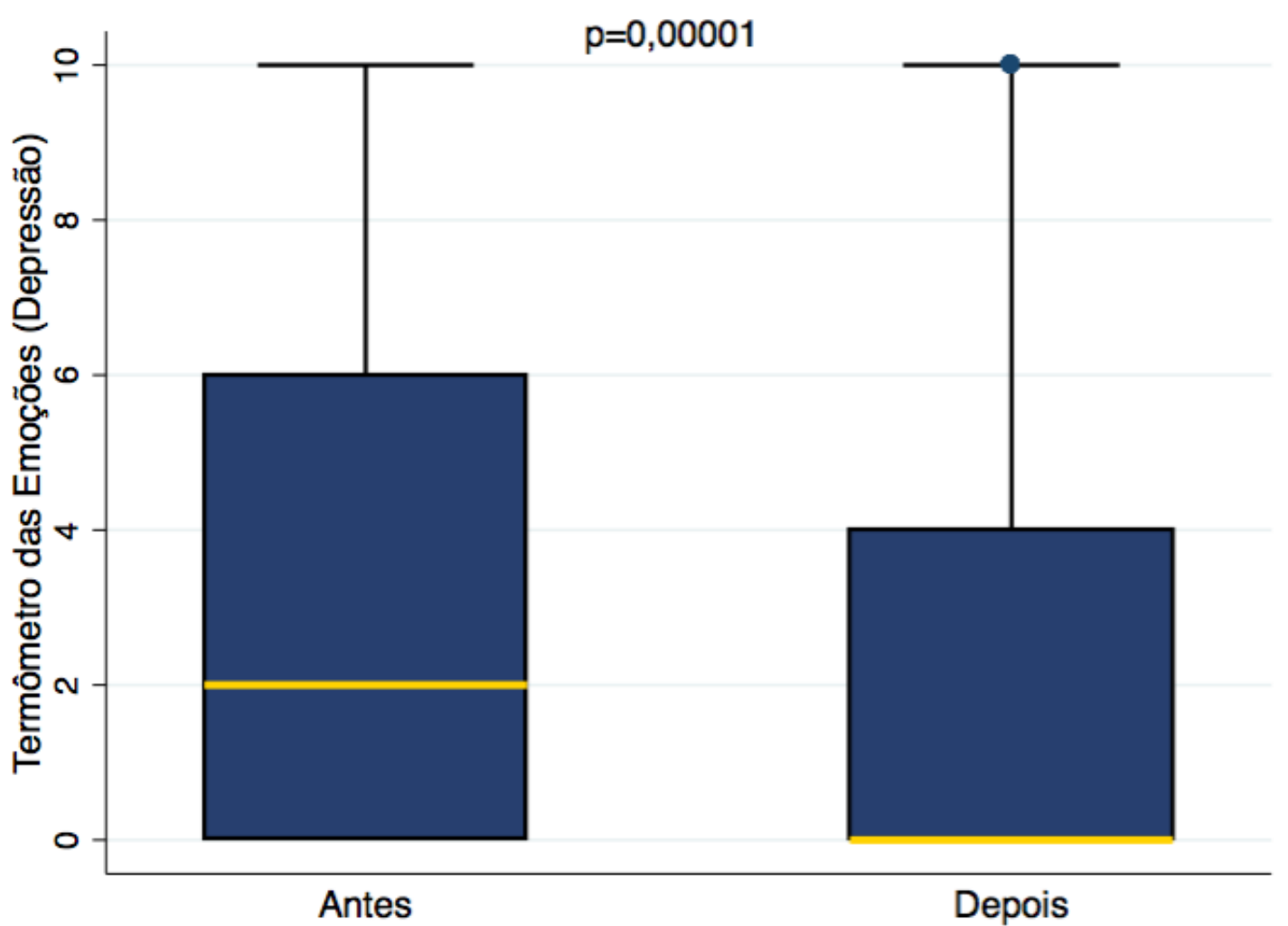

Elaboração própria

Nota: Gráfico do tipo box plot mostrando a evolução do parâmetro de depressão do termômetro das emoções antes e após a intervenção do grupo de acolhimento da sala de urgência. A linha horizontal amarela representa a mediana, as barras azuis representam os percentis P25 e P75 e as linhas horizontais pretas representam os percentis P10 e P90. 
Gráfico 5: Distribuição dos resultados da intervenção - Revolta

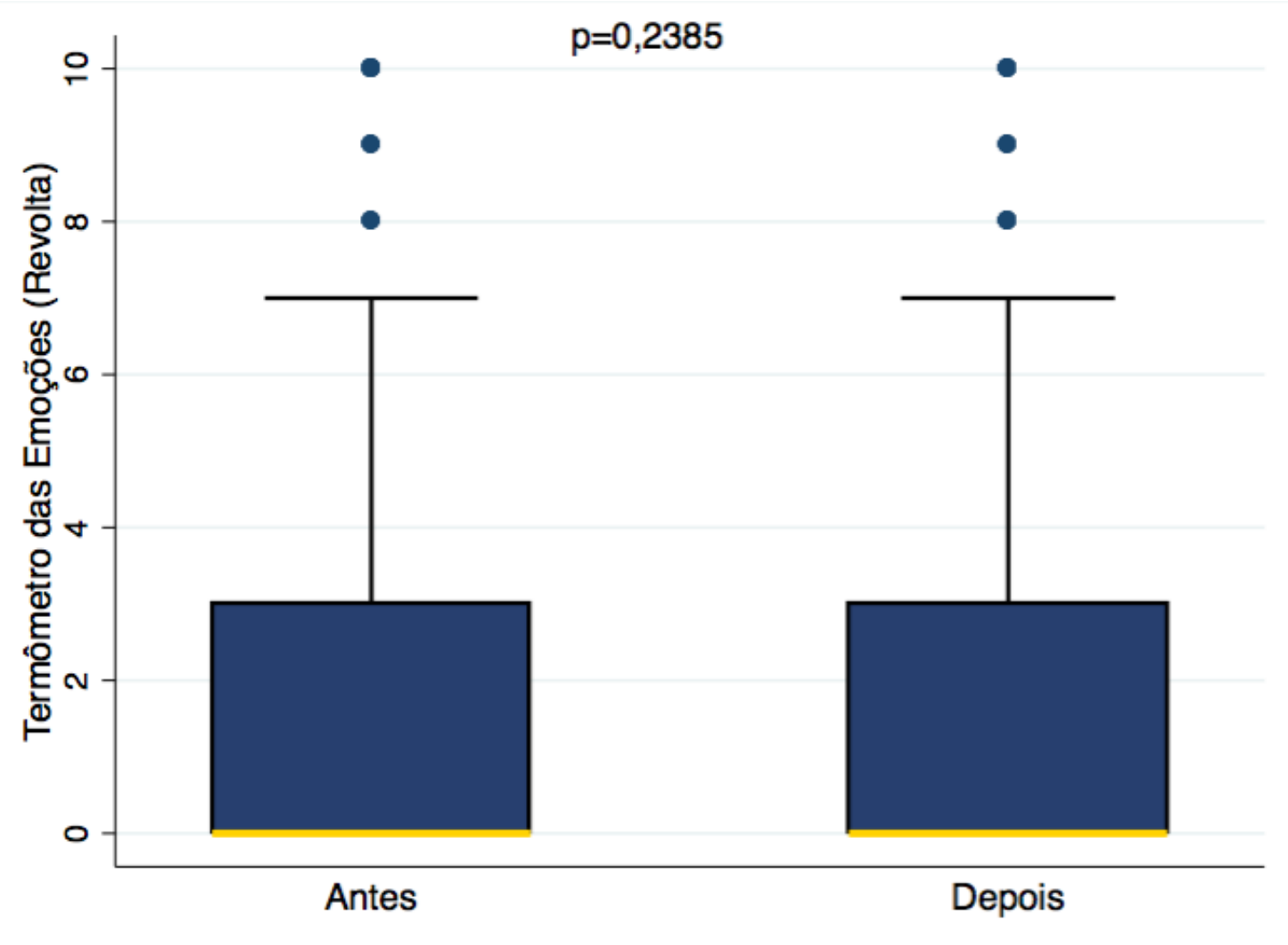

Fonte: Elaboração própria

Nota: Gráfico do tipo box plot mostrando a evolução do parâmetro de revolta do termômetro das emoções antes e após a intervenção do grupo de acolhimento da sala de urgência. A linha horizontal amarela representa a mediana, as barras azuis representam os percentis $\mathrm{P} 25$ e P75 e as linhas horizontais pretas representam os percentis P10 e P90. 
Gráfico 6: Distribuição dos resultados da intervenção - Total TE

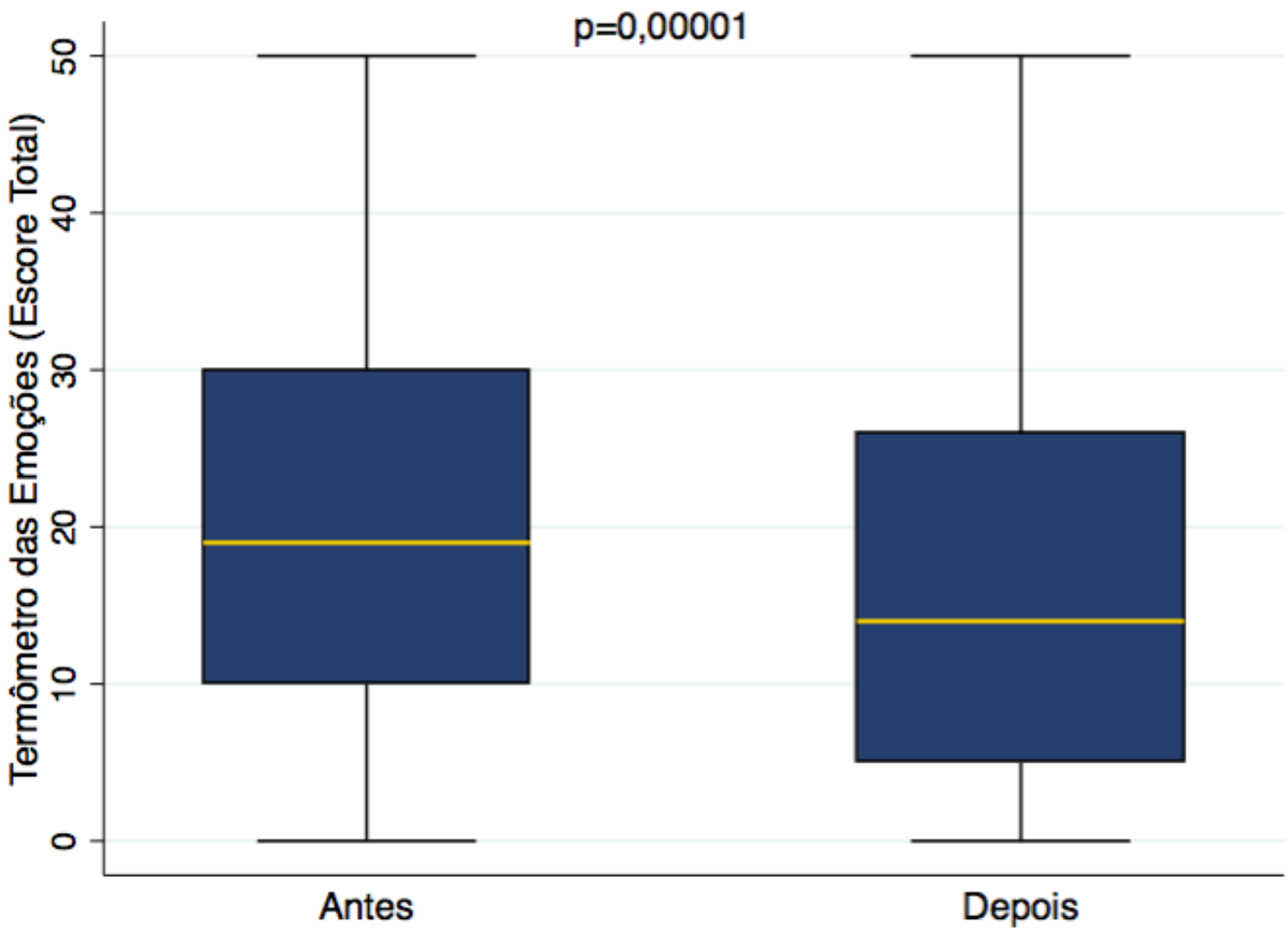

Elaboração própria

Nota: Gráfico do tipo box plot mostrando a evolução do escore soma total do termômetro das emoções antes e após a intervenção do grupo de acolhimento da sala de urgência. A linha horizontal amarela representa a mediana, as barras azuis representam os percentis P25 e P75 e as linhas horizontais pretas representam os percentis P10 e P90.

A depressão aparece com pontos baixos, o menor valor antes foi de (0 de 10 pontos) e o maior valor foi (6 de 10 pontos). E a revolta mantém-se com mínimas e máximas sem alterações Sendo revolta a menor medianas do estudo (0 de 10 pontos).

\subsection{INTERVENÇÃO EFETIVA X INTERVENÇÃO NÃO EFETIVA}

Com o intuito de se avaliar a possibilidade de identificar um perfil de acompanhante que você mais suscetível a intervenção comparou-se as características dos acompanhantes e seus respectivos pacientes entre os grupos considerados como intervenção efetiva $(n=62)$ e intervenção inefetiva $(n=116)$. Os resultados destas comparações são mostradas nas tabelas 4 e 5 . Não foi observada nenhuma diferença estatisticamente significativa entre os dois grupos analisados. 
Tabela 4. Comparação das características dos acompanhantes entre os grupos onde a intervenção foi considera efetiva versus o grupo onde a mesma foi considera sem efetividade.

\begin{tabular}{|c|c|c|c|}
\hline Características & $\begin{array}{c}\text { Intervenção } \\
\text { Efetiva } \\
\mathrm{N}=62 \\
\end{array}$ & $\begin{array}{c}\text { Intervenção } \\
\text { Inefetiva } \\
\mathrm{n}=116 \\
\end{array}$ & $\mathrm{P}$ \\
\hline Idade do acompanhante; média \pm dp & $49 \pm 16$ & $46 \pm 15$ & 0,222 \\
\hline \multicolumn{4}{|l|}{ Sexo do acompanhante; n (\%) } \\
\hline Masculino & $18(29 \%)$ & $29(25)$ & 0,561 \\
\hline Grau de parentesco; n $(\%)$ & & & 0,189 \\
\hline Filho (a) & $13(21 \%)$ & $33(28 \%)$ & \\
\hline Esposo (a) & $30(48 \%)$ & $29(25 \%)$ & \\
\hline Irmão (a) & $6(10 \%)$ & $9(8 \%)$ & \\
\hline Mãe & $4(6 \%)$ & $14(12 \%)$ & \\
\hline Outros & $9(14 \%)$ & $31(27 \%)$ & \\
\hline Escolaridade; n (\%) & & & 0,665 \\
\hline Médio incompleto & $18(29 \%)$ & $21(18 \%)$ & \\
\hline Fundamental incompleto & $9(14 \%)$ & $22(19 \%)$ & \\
\hline Fundamental completo & $20(32 \%)$ & $40(34 \%)$ & \\
\hline Superior incompleto & $8(13 \%)$ & $16(14 \%)$ & \\
\hline Outros & $7(11 \%)$ & $17(15 \%)$ & \\
\hline Ocupação; n (\%) & & & 0,535 \\
\hline Serviços gerais & $17(27 \%)$ & $32(27 \%)$ & \\
\hline Desempregado (a) & $12(19 \%)$ & $20(17 \%)$ & \\
\hline Do lar & $10(16 \%)$ & $11(9 \%)$ & \\
\hline Aposentado (a) & $6(10 \%)$ & $13(11 \%)$ & \\
\hline Autônomo & $7(11 \%)$ & $10(9 \%)$ & \\
\hline Outros & $10(16 \%)$ & $30(26 \%)$ & \\
\hline $\begin{array}{l}\text { Tempos de intervenção em relação à } \\
\text { primeira intervenção; } \mathrm{n}(\%)\end{array}$ & & & 0,344 \\
\hline $27(15 \%)$ & $10(16 \%)$ & $17(15 \%)$ & \\
\hline $12-24 \mathrm{~h}$ & $31(50 \%)$ & $39(34 \%)$ & \\
\hline $24-48 h$ & $13(21 \%)$ & $32(27 \%)$ & \\
\hline $48-96 h$ & $5(8 \%)$ & $19(16 \%)$ & \\
\hline $96-192 h$ & $3(5 \%)$ & $7(6 \%)$ & \\
\hline $2(1 \%)$ & $0(0 \%)$ & $2(2 \%)$ & \\
\hline
\end{tabular}

Fonte: Elaboração própria/ Nota: n(\%): porcentagem; (IQR): intervalo interquartil 
Tabela 5. Comparação das características dos pacientes entre os grupos onde a intervenção foi considerada efetiva versus o grupo onde a mesma foi considerada sem efetividade.

\begin{tabular}{|c|c|c|c|}
\hline Características & $\begin{array}{c}\text { Intervenção } \\
\text { Efetiva } \\
\mathrm{N}=62\end{array}$ & $\begin{array}{c}\text { Intervenção } \\
\text { Inefetiva } \\
\mathrm{n}=116\end{array}$ & $P$ \\
\hline Idade do paciente; $\mathrm{n}(\%)$ & & & 0,325 \\
\hline $17-25$ & $5(8 \%)$ & $14(12 \%)$ & \\
\hline $25-40$ & $6(10 \%)$ & $15(13 \%)$ & \\
\hline $40-60$ & $19(31 \%)$ & $21(18 \%)$ & \\
\hline $60-80$ & $27(43 \%)$ & $51(44 \%)$ & \\
\hline$>80$ & $5(8 \%)$ & $15(13 \%)$ & \\
\hline Sexo do paciente; $\mathrm{n}(\%)$ & & & 0,119 \\
\hline Masculino & $37(60 \%)$ & $55(47 \%)$ & \\
\hline Especialidade; n (\%) & & & 0,69 \\
\hline Clínica Médica & $31(50 \%)$ & $61(52 \%)$ & \\
\hline Cirurgia & $16(26 \%)$ & $27(23 \%)$ & \\
\hline Neurologia & $7(11 \%)$ & $18(16 \%)$ & \\
\hline Outros & $8(13 \%)$ & $10(9 \%)$ & \\
\hline Diagnóstico principal, n (\%) & & & 0,30 \\
\hline Câncer & $16(26 \%)$ & $14(12 \%)$ & \\
\hline Infecção & $3(5 \%)$ & $12(10 \%)$ & \\
\hline AVC & $4(6 \%)$ & $6(5 \%)$ & \\
\hline Síndrome Coronariana & $1(2 \%)$ & $8(7 \%)$ & \\
\hline Outros & $38(61 \%)$ & $76(66 \%)$ & \\
\hline Mortalidade, n (\%) & $1(02 \%)$ & $8(07 \%)$ & 0,125 \\
\hline Índice Charlson; mediana (IQR) & $2(0-4)$ & $1(0-3)$ & 0,302 \\
\hline $\begin{array}{l}\text { Índice de Charlson corrigido pela idade; } \\
\text { mediana (IQR) }\end{array}$ & $1,5(0-2)$ & $2(0-3)$ & 0,237 \\
\hline APACHE II; (IQR) & $8(6-12)$ & $9(5-14)$ & 0,415 \\
\hline $\begin{array}{l}\text { Duração internação em dias; mediana } \\
\text { (IQR) }\end{array}$ & $3(1-5)$ & $4(2-6)$ & 0,323 \\
\hline $\begin{array}{l}\text { Duração internação SU; horas; mediana } \\
\text { (IQR) }\end{array}$ & $71(28-117)$ & 69 (26-109) & 0,851 \\
\hline
\end{tabular}

Fonte: Elaboração própria

Nota: $\mathrm{n}(\%)$ : porcentagem; (IQR): intervalo interquartil 


\section{DISCUSSÃO}

A possível gravidade em saúde vivenciada em situações de urgência/emergência requer decisões rápidas e assertivas, no entanto, esta dinâmica do contexto, muitas vezes pode impactar na gestão do cuidado, sendo comum ocorrer interferências no tempo despendido para fornecer informações aos familiares e/ou repercussões estressoras de ordem traumáticas do ponto de visto psíquico à acompanhantes.

Entre os resultados encontrados na pesquisa confirmam os dados encontrados na literatura acerca do papel social de cuidadora representado pelas mulheres ao longo dos anos (NEVES et al, 2018). Para Melo, Cristo e Guihermin (2015) cerca de 83\% de uma amostra que pretendia avaliar o perfil sócio demográfico dos acompanhantes em unidades de internação de hospital público universitário em Brasília, também se caracterizava por mulheres jovens.

Também eram as acompanhantes as filhas de idosos em pesquisa desenvolvida com acompanhantes familiares de idosos em hospital público de grande porte no interior da Bahia (REIS; SENA; MENEZES, 2016)

O núcleo familiar encontrado nos graus de parentesco de cônjuge, mãe e filho(a) conotam a importância do apoio familiar nos momentos de adoecimento, o que segundo Carvalho, et al. (2019) é comum mas também é uma vivência nova e surpreendente para o familiar, que passa a experimentar uma nova rotina e enfrentar as angústias do que "está por vir".

A construção que se estabelece nessa relacional entre o acompanhante familiar que recebe oferta de cuidados no ambiente de hospitalização e o trabalhadores são as chamadas tecnologias leves, as que se atribui a relação interpessoal, que podem ser discutida entre as condições muitas condições para aprimoramento de estratégias de cuidado em humanização por possibilitar a reflexão de novos modos de fazer (MEHRY, 2003; PERES; LOPES, 2012; CAMPOS, 2005).

Grande parcela desta amostra estão trabalhando em funções diversas que não foram descritas, o que difulta a correlação com outros estudos. As condição de desemprego, por outro lado, apesar de ser tema pouco trazido nos estudos que envolvem o cuidado aos acompanhantes é uma condição ambivalente já que, significa estar com tempo disponível para o acompanhamento, no entanto, também pode ser um agravamento social, podendo gerar preocupação. 
Fica claro que, para além do enfermo, a família também passa a vivenciar a rotina de cuidados em saúde e o modo como se oferece a intervenção apresenta-se como uma ferramenta imprescindível para acolhimento, engajamento no tratamento e também redução de futuros adoecimentos psíquicos.

Lacerda e demais pesquisadores (2017) destacam que o interesse em estudos envolvendo as famílias dos doentes e suas vivências emocionais vêm crescendo no Brasil devido inúmeras evidências de sobrecarga dos cuidadores.

Os estudos encontrados na literatura científica com a utilização do termômetro das emoções envolveram sua aplicação junto à pacientes, em sua maioria oncológicos e pelo nosso conhecimento não encontramos nenhuma investigação que avaliou o mesmo em um ambiente de emergência comparando o pré e pós teste após uma intervenção, este fato dificulta as comparações, porém por outro lado, evidenciam a originalidade do estudo.

Consideramos os resultados apresentados com a intervenção do grupo de acolhimento da sala de urgência com uma taxa de efetividade de $35 \%$ como relevante. Pois observou-se uma resposta positiva em cerca de 1/3 da amostra. Geralmente intervenções deste tipo mostram taxas de efetividades variáveis, mas já é sabido que nem todos indivíduos respondem a algum tipo de intervenção. Apesar de não ser o objetivo deste estudo, pela experiência observada parece que o termômetro das emoções é um instrumento adequado para se avaliar as repercussões emocionais desencadeadas no acompanhante durante a hospitalização de um parente.

Experiência relatada junto à acompanhantes e familiares de usuários com lesão medular em um hospital de emergência e trauma em Fortaleza destaca as repercurssões positivas vivenciadas pelo hospital ao longo das intervenções que tinham como objetivo garantir informação e formação, ensinando os acompanhantes os cuidados de enfermagem que deveriam ser ofertados diariamente na rotina hospitalar (CARVALHO; et al., 2019)

Nos grupos destinados à familiares, as relações interpessoais possíveis de serem construídas funcionam como subsídios para o enfrentamento da realidade, situação esta que funciona como um fator moderador do estresse experimentado (PISKE et al., 2013).

A ansiedade, representando a emoção com o mais alto escore observado nos termômetros das emoções corrobora com estudos que se propuseram a avaliar os sintomas de ansiedade em acompanhantes em cenário hospitalar, especialmente em 
condição de gravidade que discutem a sensação do desconhecido como uma experiência desagradável (MARIUTI; GALEANO; FARAH, 2007).

Salienta-se de fundamental importância mencionar nesta discussão a redução no termômetro das emoções em relação a maior parte dos parâmetros analisados, exceto em relação ao sentimento de revolta, o que pode estar associado a oferta de espaço para relaçoes interpessoais, acolhimento multiprofissional e acesso à informação já que, a falta de comunicação é uma das maiores insatisfações dos acompanhantes e também amplamente mais mencionadas nos estudos que envolvem a realidade dos serviços de emergência (ANDRADE; MARTINS; CAETANO, 2019).

O humor irritável e triste caracteriza alguns dos principais sintomas dos episódios depressivos, que apareceram timidamente nos TE. Fato bastante comum na autopercepção das fragilidades em saúde mental, mas bastante incomum acerca dos achados que mediram interveções com acompanhantes em ambientes hospitalares MARIUTI; GALEANO; FARAH, 2007).

Sinônimo de grande pertubação, a revolta foi a emoção em que não foi encontrada significância estatística no pré e pós testes, contudo observa-se um escore muito baixo na pré-intervenção, mostrando que este sentimento não parece ser muito frequente entre os acompanhantes de pacientes hospitalizados em condições de emergência.

Diferentes estudos foram realizados no país para caracterizar amostras de prontoatendimentos hospitalares já que, objetiva-se identificar este perfil de clientela a fim de criar mecanismos que possam auxiliar na superlotação vivenciada pelos serviços de emergência. Percebe-se que há grande variabilidade nos estudos encontrados acerca do perfil dos usuários dependento de cada localidade e cada tipo de hospital.

Mesmo se tratando de um hospital de referência terciária, observou-se um escore de APACHE relativamente baixo nesta amostra. Nota-se ainda que, mais da metade destes usuários estavam em atendimento por urgências clínicas de baixa gravidade, que além de serem as mais comuns, representam segundo O'dwyer (2009) questões que poderiam ser resolvidas à nível ambultorial.

Em relação a intervenção em grupos de acompanhantes, consideramos uma alternativa adequada, pois com o grande volume de pacientes e acompanhantes nas salas de urgência uma abordagem individualizada é praticamente impossível. Por outro lado, o termômetro das emoções também poderia ser uma ferramenta que ajudaria a selecionar aqueles acompanhantes que estão apresentando uma maior repercussão 
emocional e que mereceriam uma intervenção mais individualizada pela equipe multiprofissional.

Pela análise realizada também não foi possível se identificar um perfil de acompanhante mais suscetível a intervenção, desta forma a mesma deveria ser oferecida a todos os acompanhantes. De fato, esta reação emocional em relação ao parente hospitalizado parece ser um resposta muito individual e que seria difícil de ser prevista a partir de características sociodemográficas e clínicas relacionadas ao acompanhante e ao paciente.

\section{LIMITAÇÕES}

Entre as limitações encontradas nesta pesquisa destaca-se que pela dinâmica da Sala de Urgência, os acompanhantes percebendo a gravidade do adoecimento de seus parentes muitas vezes não conseguirem se ausentar e participar da intervenção em grupo proposta, este fato poderia se constituir em um viés de seleção, onde os acompanhantes de pacientes com maior gravidade tiveram uma menor chance de participarem deste grupo de intervenção.

Este estudo não avaliou diretamente o impacto desta intervenção através do grupo de acolhimento da sala de urgência na pesquisa de satisfação do usuário em relação ao atendimento ofertado, assim como, no número de reclamações de acompanhantes na ouvidoria. Considera-se que esta intervenção poderia mostar repercussão direta nestes indicadores hospitalares.

Apesar do treinamento e padronização das informações ofertadas no grupo de acolhimento, o mesmo foi realizado por diferentes profissionais da equipe multiprofissional, este fato pode ter causado certa heterogeneidade entre os diferentes grupos realizados.

\section{CONCLUSÃO}

Intervenção através de um grupo de acolhimento a acompanhantes de pacientes hospitalizados em uma sala de emergência parece ser efetiva para redução da tensão emocional desencadeada nos acompanhantes. Este tipo de intervenção apresentou uma taxa de efetividade de 35\%. Não foi possível identificar um perfil de acompanhante mais suscetível a este tipo de intervenção. 


\section{REFERÊNCIAS}

ANDRADE, Luciene Miranda de et al. Atendimento humanizado nos serviços de emergência hospitalar na percepção do acompanhante. Rev. Eletr. Enf., Fortaleza, v.11, n.1, p.151-7, 2009.2 Disponível em: $<$ http://www.fen.ufg.br/revista/v11/n1/v11n1a19.htm. $>$ Acesso em: jul 2019.

ASSIS, Luana de. O planejamento estratégico de um hospital universitário federal e sua atuação regional nas políticas públicas de saúde.2017.249f.Dissertação (Mestrado em Planejamento e Governança Pública) - Programa de Pós-Graduação em Planejamento e Governança Pública (PPGPGP), Universidade Tecnológica Federal do Paraná (UTFPR). Curitiba, 2017.

BATISTA, Dinha. Acolhimento e Humanização para acompanhantes: A inserção do Serviço Social e da Enfermagem de uma Instituição Federal. 2009. Portal Rede HumanizaSus. Disponível em: <http://redehumanizasus.net/7120-acolhimento-ehumanizacao-para acompanhantes-a-insercao-do-servico-social-e-da-enfermagem-deuma-instituicao-federal/> Acesso em: jul 2019.

BATISTA, Marco Jacob. et al. Presença de familiares durante situações de emergência: a opinião dos enfermeiros do serviço de urgência de adultos. Revista de Enfermagem Referência, Almada, v.13, n.4, p. 83-92, 2017.

BONFÁ, E. S. D. O. Acolhimento com avaliação de risco nas Unidades de Urgência e Emergência referenciadas do Hospital das Clínicas da FMUSP. Documento eletrônico. Núcleo Técnico e Científico de Humanização. São Paulo, 2014.

BRASIL. Estatuto da Criança e do Adolescente, Câmera dos Deputados, Lei no 8.069, de 13 de julho de 1990. DOU de 16/07/1990 - ECA. Brasília, DF.

Lei n.11.108, de 07 de abril de 2005. Altera a Lei 8.080, introduzindo o direito ao acompanhante de escolha durante o trabalho de parto, no parto e no pós-parto imediato. Diário Oficial da União, Brasília, DF, n.67, 8 abr. 2005. Seção 1, p.1.

Lei n. ${ }^{\circ} 10.741$, de 01 de outubro de 2003. Estatuto do Idoso. Diário Oficial da União, Brasília (DF). Recuperado em 02 fevereiro, 2012, de: http://www.planalto.gov.br/ccivil_03/leis/2003/L10.741.htm.

BRASIL. Ministério da Saúde. Manual de planejamento no SUS / Ministério da Saúde, Fundação Oswaldo Cruz. - 1. ed., rev. - Brasília : Ministério da Saúde, 2016. 138 p. : il. - (Série Articulação Interfederativa ; v. 4)

Ministério da Saúde. Portaria No 1.600, de 7 de julho de2011. Reformula a Política Nacional de Atenção às Urgências e institui a Rede de Atenção às Urgências as no Sistema Único deSaúde (SUS). Diário Oficial [da] República Federativa do Brasil,Brasília, DF, 7 jul. 2011b.

Ministério da Saúde. Secretaria de Atenção à Saúde. Departamento de Atenção Especializada. Manual instrutivo da Rede de Atenção às Urgências e Emergências no Sistema Único de Saúde (SUS) / Ministério da Saúde, Secretaria de Atenção à 
Saúde, Departamento de Atenção Especializada. - Brasília: Editora do Ministério da Saúde, 2013.

- Ministério da Saúde. Secretaria de Atenção à Saúde. Núcleo Técnico da Política Nacional de Humanização. HumanizaSUS: visita aberta e direito a acompanhante / Ministério da Saúde, Secretaria de Atenção à Saúde, Núcleo Técnico da Política Nacional de Humanização. - 2. ed. - Brasília: Ministério da Saúde, 2007. 32 p.: il. - (Série B. Textos Básicos de Saúde)

Ministério da Saúde. Secretaria de Atenção à Saúde. Política Nacional de Humanização. HumanizaSUS: gestão participativa: co-gestão / Ministério da Saúde, Secretaria de Atenção à Saúde, Política Nacional de Humanização. - 2. ed. rev. - Brasília: Editora do Ministério da Saúde, 2009.

Ministério da Saúde. Secretaria de Gestão do Trabalho e da Educação na Saúde. Departamento de Gestão da Educação em Saúde. Política Nacional de Educação Permanente em Saúde / Ministério da Saúde, Secretaria de Gestão do Trabalho e da Educação na Saúde, Departamento de Gestão da Educação em Saúde. - Brasília : Ministério da Saúde, 2009. 64 p. - (Série B. Textos Básicos de Saúde) (Série Pactos pela Saúde 2006; v. 9)

Resolução $n^{\circ}$. 3, de 20 de junho de 2014. Institui Diretrizes Curriculares Nacionais do Curso de Graduação em Medicina e dá outras providências. Ministério da Saúde. Brasília, DF, 20.jun.2014.

Secretaria-Executiva. Núcleo Técnico da Política Nacional de Humanização. HumanizaSUS: Política Nacional de Humanização. Folheto. $1^{\mathrm{a}}$ edição. $1^{\mathrm{a}}$ reimpressão. Brasilia 2013.

Secretaria-Executiva. Núcleo Técnico da Política Nacional de Humanização. HumanizaSUS: Política Nacional de Humanização: a humanização como eixo norteador das práticas de atenção e gestão em todas as instâncias do SUS. Brasília: Ministério da Saúde, 2004.

CAMPOS, Gastão Wagner de Sousa. Humanização na saúde: um projeto em defesa da vida? Interface - Comunic, Saúde, Educ, v.9, n.17, p.389-406, mar/ago. 2005. Disponível em: < http://www.scielo.br/pdf/icse/v9n17/v9n17a16.pdf > Acesso em: maio 2019.

CAMPOS, Gastão Wagner de Sousa; AMARAL, Márcia Aparecida do. A clínica ampliada e compartilhada, a gestão democrática e redes de atenção como referenciais teórico-operacionais para a reforma do hospital. Ciênc. saúde coletiva, Rio de Janeiro , v. 12, n. 4, p. 849-859, Aug. 2007. Disponível em: $<$ http://www.scielo.br/scielo.php?script=sci_arttext\&pid=S1413$81232007000400007 \& \operatorname{lng}=$ en\&nrm=iso $>$.

CAMPOS, Gastão Wagner de Sousa; CAMPOS, Rosana Teresa Onocko. Gestão em Saúde. In: PEREIRA, Isabel; LIMA, Júlio César França. Dicionário de educação profissional em saúde. Rio de Janeiro Escola Politécnica de São Joaquim Venâncio: Rev. Ampl., n.2, 2008. p.231 
CARVALHO, Zuila Maria de Figueiredo et al. Paciente com lesão raquimedular: experiência de ensino-aprendizagem no cuidado para família. Esc. Anna Nery, Fortaleza,
v. 10 ,
n.2,
p.316-322.
2019
Disponível
em:

$<$ http://revistaenfermagem.eean.edu.br/detalhe artigo.asp?id=119. Acesso em: jul 2019.

CURTIS, J. R. et al. Randomized Trial of Communication Facilitators to Reduce Family Distress and Intensity of End-of-life Care. AJRCCM., p.2-34, set. 2015. Disponível em: <http:// www.atsjournals.org. >. Acesso em: setembro 2016.

DAL PAI, Daiane; LAUTERT, Liana. Suporte humanizado no pronto socorro: um desafio para a enfermagem. Rev. bras. enferm., Brasília, v. 58, n. 2, p. 231-234, Apr. 2005 Disponível em:

$<$ http://www.scielo.br/scielo.php?script=sci_arttext\&pid=S0034-

$71672005000200021 \& \operatorname{lng}=\mathrm{en} \& n r m=i s o>$. Acesso em: jul 2019.

DECAT, Cristiane de Sant'anna; ARAÚJO, Tereza Cristina Cavalvanti Ferreira de. Avaliação diagnóstica do distress : contribuições para rotina de atendimento em serviço de oncologia. Dissertação (mestrado) - Universidade de Brasília, Instituto de Psicologia, Programa de Pós-Graduação Processos de Desenvolvimento Humano e Saúde, 2008.

DECAT, Cristiane Sant'Anna; LAROS, Jacob Arie; ARAUJO, Tereza Cristina Cavalcanti Ferreira de. Termômetro de Distress: validação de um instrumento breve para avaliação diagnóstica de pacientes oncológicos. Psico-USF (Impr.), Itatiba, v. 14, n. 3,p. 253-260, Dec. 2009. Disponível em:

<http://www.scielo.br/scielo.php?script=sci_arttext\&pid=S141382712009000300002\&1 ng=en\&nrm=iso>. Acesso em: jul 2019.

DIAS, Cláudia; CRUZ, José Fernando; FONSECA, António Manuel. Emoções: passado, presente e futuro. Psicologia, Lisboa, v. 22, n. 2, p. 11-31, jul. 2008. Disponível em: < http://www.scielo.mec.pt/scielo.php?script=sci_arttext\&pid=S0874-

20492008000200002>. Acesso em: jul 2019.

DIAS, Maria João Cunha; VELHO, Glória Cunha. Impacto psicossocial da acne: influência do tratamento com isotretinoína. (Dissertação com vista à atribuição do grau de Mestrado). Porto: Mestrado Integrado em Medicina (MIM) do ICBAS/UP; 2014.

FEIJO, Vivian Biazon El Reda et al . Análise da demanda atendida em unidade de urgência com classificação de risco. Saúde debate, Rio de Janeiro , v. 39, n. 106, p. 627636, Sept. 2015 Disponível em: <http://www.scielo.br/scielo.php?script=sci_arttext\&pid=S010311042015000300627\&lng=en\&nrm=iso>. Acesso em: jul 2019

FERRERAS GONZÁLEZ, $M^{\mathrm{a}}$ Carmen; CARMEN, $\mathrm{M}^{\mathrm{a}}$. Percepción de las enfermeras de la Unidad de Urgencias del Complejo Asistencial Universitario de León sobre la presencia de acompa nantes en los boxes de adultos Perception regarding the presence of patient companions in the adult Emergency Care Ward among nurses in León Universitary Hospital. Med Intensiva, v. 41, n. 9, p. 575-576, 2017. 
FOUCAULT, Michel. Espaços e Classes. In: FOUCAULT, Michel(org). O nascimento da clínica. Rio de Janeiro: Forense Universitária, 1977. p. 19.

FRANÇA, Dorane. Acolhimento e humanização para acompanhantes: a inserção do serviço social no atendimento humanizado, 2014. Portal Rede HumanizaSus. Disponível em: $\quad<$ http://redehumanizasus.net/84129-acolhimento-e-humanizacao-paraacompanhantes-a-insercao-do-servico-social-no-atendimento-humanizado/> Acesso em: jul 2019.

GONÇALVES, Monteiro Alexandre; et.al. A Relevância do Planejamento Estratégico na Administração Pública. Revista Científica Multidisciplinar Núcleo do Conhecimento. Ano 03, Ed. 04, v. 2, pp. 148-158, 2018.

LACERDA, M. R. Cuidado domiciliar: em busca da autonomia do indivíduo e da família: na perspectiva da área pública. Ciência \& Saúde Coletiva, Rio de Janeiro, v. 15, n. 5 , p. 2621-2626, 2010. Disponível em: <http://www.scielo.br/pdf/csc/v15n5/v15n5a36.pdf>. Acesso em: jul 2019.

MARUITI, Marina Rumiko; GALDEANO, Luzia Elaine; FARAH, Olga Guilhermina Dias. Ansiedade e depressão em familiares de pacientes internados em unidade de cuidados intensivos. Acta paul. enferm., São Paulo, v. 21, n. 4, p. 636-642, 2008 . Disponível em: <http://www.scielo.br/scielo.php?script=sci_arttext\&pid=S0103$21002008000400016 \& \operatorname{lng}=\mathrm{en} \& n r m=i s o>$. Acesso em: jul 2019.

MELO, Manuela Costa; CRISTO, Rosilane De Carvalho, GUILHEM, Dirce. Perfil sociodemográfico de acompanhantes de pacientes e suas concepções sobre atenção recebida. Revista Eletrônica Gestão \& Saúde, Brasília, v.6, n. 2, p. 1550- 64, 2015.

MERHY, Emerson Elias. Planejamento como tecnologia de gestão: tendências e debates sobre planejamento de saúde no Brasil. In: Gallo Edmundo, organizador. Razão e planejamento. Reflexões sobre política, estratégia e liberdade. São Paulo: Hucitec; Rio de Janeiro: Abrasco; 1995.

MERHY, Emerson Elias; FRANCO, T.B. Por uma composição técnica do trabalho em saúde centrada no campo relacional e nas tecnologias leves. Apontando mudanças para os modelos tecnoassistenciais. Saude em Debate, Campinas, v.27, n.65, p.316-2, 2003..

NEINKOTTER, Sheila Maria Valetim. Acolhimento aos acompanhantes de pessoas adultas em situação crítica de saúde em serviço de emergência. Dissertação (mestrado) Universidade Federal de Santa Catarina, Centro Ciências de Saúde. Programa de PósGraduação em Enfermagem; 2011.

NEVES, Letícia et al. O impacto do processo de hospitalização para o acompanhante familiar do paciente crítico crônico internado em Unidade de Terapia Semi-Intensiva. Esc. Anna Nery, Fortaleza v.22, n.2, p.1-8, jan. 2018. Disponível em: < http://www.scielo.br/pdf/ean/v22n2/pt_1414-8145-ean-2177-9465-EAN-2017-

0304.pdf> Acesso em: jul 2019.

NOMURA, A. B. N. Rede de Urgência e Emergência. São Paulo. Junho, 2013. Documento eletrônico. Disponível em: <http://www.saude.sp.gov.br/resources/ses/perfil/gestor/homepage/auditoria/reunioes/re de_urg emerg_adalgisa_borges.pdf $>$. Acesso em: setembro 2016. 
O'DWYER, Gisele Oliveira; OLIVEIRA, Sergio Pacheco de; SETA, Marismary Horsth de. Avaliação dos serviços hospitalares de emergência do programa QualiSUS. Ciênc. saúde coletiva, Rio de Janeiro , v. 14, n. 5, p. 1881-1890, dec. 2009 . Disponível em: $<$ http://www.scielo.br/scielo.php?script=sci_arttext\&pid=S141381232009000500030\&lng=en\&nrm=iso >. Acesso em: jul 2019.

PEREIRA, M.G., TEIXEIRA, R., FIGUEIREDO, A.P. Rastreio emocional breve de doentes em quimioterapia: um projecto português. Comunicação apresentada no $11^{\circ}$ Congresso Brasileiro de Psico-Oncologia, IV Encontro Internacional de Cuidados Paliativos em Oncologia, Copacabana, Brasil, 2010.

PERES, Girlane Mayara; LOPES, Ana Maria Pereira. Acompanhamento de pacientes internados e processos de humanização em hospitais gerais. Psicol. hosp. (São Paulo), São Paulo , v. 10, n. 1, p. 17-41, jan. 2012 . Disponível em $<$ http://pepsic.bvsalud.org/scielo.php?script=sci_arttext\&pid=S16777409201200010000 $3 \& \operatorname{lng}=$ pt\&nrm=iso $>$. acessos em 24 jul. 2019.

PINHO, LB; KANTORSKI, LP.Condições de atendimento na unidade de emergência: um estudo qualitativo com famílias de pacientes. Fam. Saúde Desenv., Curitiba, v.8, n.3, p.223-232, set./dez. 2006.

PISKE, Fernanda et al. Revista Psicologia: Teoria e Prática, São Paulo, v.15, n.1, p.3549. jan.-abr. 2013.

PRADO, Marta Lenise do et al. Arco de Charles Maguerez: Refletindo estratégias de metodologia ativa na formação de profissionais de saúde. Escola Anna Nery - Revista de Enfermagem, v.16, n.1, p.172-177, 2012.

REIS, Camila Calhau Andrade; SENA, Edite Lago da Silva; MENEZES, Tânia Maria de Oliva. Vivências de familiares cuidadores de pessoas idosas hospitalizadas e a experiência de intercorporeidade. Esc. Anna Nery, Rio de Janeiro, v. 20, n. 3, e20160070, abr 2016 Disponível em:

<http://www.scielo.br/scielo.php?script=sci_arttext\&pid=S141481452016000300214\&lng=en\&nrm=iso>. Acesso em: jul 2019.

RIBAS, Eliana. Cuidado integral na instituição hospitalar. Prattein - Consultoria em Educação e Desenvolvimento Social. Junho, 2006. Disponível em: $<$ http://www.prattein.com.br/prattein/dados/anexos/125 2.pdf $>$. Acesso em: set 2016.

RIVERA, Francisco Javier Uribe; ARTMANN, Elizabeth. Planejamento e gestão em saúde: histórico e tendências com base numa visão comunicativa. Ciênc. saúde coletiva, Rio de Janeiro , v. 15, n. 5, p. 2265-2274, ago. 2010. Disponível em:

$<$ http://www.scielo.br/scielo.php?script=sci_arttext\&pid=S141381232010000500002\&l ng=en\&nrm=iso $>$. Acesso em: 10 jul. 2019.

RIVERA, Francisco Javier Urive. Planejamento em Saúde. In: PEREIRA, Isabel; LIMA, Júlio César França. Dicionário de educação profissional em saúde. Rio de Janeiro Escola Politécnica de São Joaquim Venâncio: Rev. Ampl., n.2, 2008. p.312. 
SANCHES, Ieda Cristina Pereira et al . Acompanhamento hospitalar: direito ou concessão ao usuário hospitalizado?. Ciênc. saúde coletiva, Rio de Janeiro , v. 18, n. 1, p. 67-76, Jan. 2013 . Disponível em: <http://www.scielo.br/scielo.php?script=sci_arttext\&pid=S1413$81232013000100008 \& \operatorname{lng}=$ en\&nrm=iso $>$. Acesso em: jul 2019. 
APÊNDICE A - GRUPO DE ORIENTAÇÕES AOS ACOMPANHANTES DA SALA DE URGÊNCIA

UNIDADE DE EMERGÊNCIA DO HOSPITAL DAS CLÍNICAS DA FACULDADE DE MEDICINA DE RIBEIRÃO PRETO DA UNIVERSIDADE DE SÃO PAULO

GRUPO DE ORIENTAÇÕES AOS ACOMPANHANTES DA SALA DE URGÊNCIA

Aline Cristina Antonechen

Francine de Castro Alves Victal

Hellen Taciane Paschoalotto Leite

Silva

Jenifer Keller de Oliveira Cabral Juliana Carla Delsim

Paloma Paloma Mithie Reboucas

Ynohaie

Thereza Cristina Pereira Lunardi

RIBEIRÃO PRETO

2018 


\section{INTRODUÇÃO}

A Unidade de Emergência do Hospital das Clínicas da Faculdade de Medicina de Ribeirão Preto da Universidade de São Paulo (UE-HCFMRP- USP) integra o Complexo do Hospital das Clínicas da Faculdade de Medicina de Ribeirão Preto da Universidade de São Paulo (HCFMRP- USP) que é um hospital prestador de assistência à saúde de nível terciário.

O atendimento na UE-HCFMRP- USP é destinado $100 \%$ aos usuários do Sistema Único de Saúde (SUS) da macrorregião de Ribeirão Preto do estado de São Paulo e do Departamento Regional de Saúde XIII (DRS XIII), abrangendo cerca de 4 milhões de pessoas. Além disso, integra a Rede de Urgência e Emergência (RUE) do DRS XIII, que compreende 26 municípios e da Rede Regional de Atenção à Saúde XIII (RRAS XIII), que engloba também os DRS de Franca, Araraquara e Barretos.

Assim, a UE-HCFMRP- USP constitui-se de uma das principais portas de entrada da RUE XIII e RRAS XIII, sendo referência no atendimento de urgência e emergência para casos de maior complexidade que em outras unidades de saúde avaliaram a necessidade do usuário ser atendimento em tal situação. Tal porta de acesso amplia e qualifica o acesso humanizado e integral aos usuários em situação de urgência e emergência, de forma resolutiva, ágil e oportuna.

Os encaminhados dos usuários para a UE-HCFMRP-USP são realizados pela Central Municipal de Regulação Médica (CMRM) ou pela Central de Regulação de Ofertas de Serviços de Saúde da Secretaria Estadual de Saúde - SP (CROSS) ou até mesmo pela Central de Regulação Federal.

Cabe ressaltar que às Centrais de Regulação Médica recebem e avaliam as solicitações de internação ou transferência hospitalar, estabelecendo as prioridades e o fluxo de usuários nos hospitais conveniados ao SUS.

Os usuários que são admitidos à UE-HCFMRP-USP contam com um corpo clínico médico especializado, equipe de enfermagem, além de uma equipe multidisciplinar compostas por assistentes sociais, terapeutas ocupacionais, nutricionistas, psicólogos, farmacêuticos, fonoaudiólogos e fisioterapeutas.

Em virtude da especificidade dos casos atendidos em um hospital de urgência, no qual atende usuários previamente saudáveis com quadros agudos 
de natureza clínica ou traumática, ou com doenças crônicas exacerbadas temos linhas de cuidado, tais como violência sexual, trauma, infarto agudo do miocárdio (IAM), acidente vascular cerebral (AVC), sepse, doenças respiratórias, e cuidados paliativos, entre outras.

Nos últimos anos, tem aumentado a demanda assistencial nas redes de urgência e emergência. Além disso, o perfil da população assistida modificou, sendo que os usuários atendidos apresentam maior complexidade. Nesse sentido, se faz necessário o desenvolvimento de práticas multiprofissionais integradas, linhas de cuidados e criação de projetos voltados para humanização no acolhimento.

Cabe mencionarmos que somos uma unidade hospital que tem como visão: ser reconhecido nacional e internacionalmente como referência em atenção à saúde, geração de conhecimento, formação e capacitação profissional para a valorização da vida, a missão de desenvolver e praticar assistência, ensino e pesquisa em saúde, por meio da busca permanente da excelência, contribuindo para a melhoria da qualidade de vida da população e seus valores são a ética, humanismo, responsabilidade social, pioneirismo e inovação, competência pessoal, comprometimento institucional, e compromisso com a qualidade.

Dentro da visão, missão e valores da UE somos uma unidade hospitalar que valoriza os princípios da Política Nacional e Estadual de Humanização e há esforços e uma preocupação em prestar um atendimento cada vez mais humanizado e respeitando os usuários na sua totalidade considerando seus aspectos físicos, psicológicos, sociais e espirituais.

Humanizar se traduz, então, como inclusão das diferenças nos processos de gestão e de cuidado. Tais mudanças são construídas não por uma pessoa ou grupo isolado, mas de forma coletiva e compartilhada. Incluir para estimular a produção de novos modos de cuidar e novas formas de organizar o trabalho. (PNH, 2013, pg 3)

É nessa busca de prestar um atendimento cada vez mais humanizado, que desde a entrada até a saída dos usuários e seus acompanhantes, que utilizamos uma das diretrizes da Política Nacional de Humanização para nortear nosso atendimento, que é o acolhimento. 
São nesses novos modos de cuidar que buscarmos ofertar um atendimento de qualidade não apenas com um gesto afetivo, mas, sobretudo, efetivo em todas as dependências da UE, desde a admissão dos usuários e seus acompanhantes até sua saída.

Em síntese, o acolhimento deve ser compreendido como ato de acolher como uma ação de aproximação, um "estar com" e um "estar perto de", ou seja, uma atitude de inclusão dos pacientes e acompanhantes que estão chegando numa unidade de urgência e emergência. Segundo a PNH,

Acolhimento O QUE É? Acolher é reconhecer o que o outro traz como legítima e singular necessidade de saúde. $O$ acolhimento deve comparecer e sustentar a relação entre equipes/serviços e usuários/ populações. Como valor das práticas de saúde, o acolhimento é construído de forma coletiva, a partir da análise dos processos de trabalho e tem como objetivo a construção de relações de confiança, compromisso e vínculo entre as equipes/serviços, trabalhador/equipes e usuário com sua rede socioafetiva. COMO FAZER? Com uma escuta qualificada oferecida pelos trabalhadores às necessidades do usuário, é possível garantir o acesso oportuno desses usuários a tecnologias adequadas às suas necessidades, ampliando a efetividade das práticas de saúde. Isso assegura, por exemplo, que todos sejam atendidos com prioridades a partir da avaliação de vulnerabilidade, gravidade e risco. (PNH, 2013, pg 6 e 7).

\section{JUSTIFICATIVA}

"nossa senhora! Você morre um pouco (...) a gente morre aos poucos, porque já faz 44 anos que somos casados, 44 anos... Então, sou eu para ele e ele para mim, [...] e quando acontece uma coisa dessas afunda o chão [...]" (FA 7) “(...) entrei em pânico a hora que eu vi que a ambulância não chegava, minha mãe não me respondia (...) senti impotência(...). Eu sinceramente acho que não sirvo para estar com alguém assim (...). Acho que não sei o que fazer. Sabe quando você tem a impressão de que(...) falhou (choro) (...) de que você deveria ter feito mais, melhor. Você poderia ter feito melhor(...) é essa a sensação(...) de que eu tinha que ter feito alguma coisa e eu não fiz(...)."(FA 6) “(...) cheguei no corredor e já escutei meu marido cair na cozinha, quando cheguei lá ele estava branco, mas branco (...) já sentado, mas não abria o olho 
(...) e fazia com as mãos (...) procurando lugar para se apoiar para levantar. Aí eu fui tentando, tentando até que levei ele para cama (...) Estávamos só nós dois em casa" (FA 10)

É com essa angustia e mistura de sentimentos que recebemos os familiares que acompanham os usuários neste serviço. A necessidade de atendimento de urgência demanda da equipe, alem do conhecimento técnico relacionado á saúde física, o cuidado com a saúde emocional. (SILVA, 2010)

Apesar de o convívio com uma doença crônica ser um processo vivido e acompanhado por algumas famílias, a ocorrência de agravo à saúde apresentase como ruptura e desorganização, é uma nova vivência cercada pelo medo e a incerteza, gerando a sensação de insegurança.

A sala de urgência da Unidade de Emergência do HCFMRP-USP recebe os usuários nas suas 24 horas de atendimento sendo permitido 01 acompanhante 24 horas com direito a revezamento e visitantes das 13h:00 as 21h:00, portanto por nossos corredores percorrem pessoas angustiadas, recebendo todo tipo de diagnóstico, notícias que apaziguam, mas que em sua maioria entristecem.

Em função da alta demanda a equipe da sala de urgência, muitas destas demandas emocionais não são atendidas, o que pode elevar a sensação de insegurança e disparar conflitos.

O acompanhante na sala de urgência é liberado nas 24 horas até que usuário receba alta, ou seja, encaminhado a uma enfermaria. Sua presença é importante para dar informações a respeito da ocorrência do agravo, do histórico de adoecimento, auxilio a equipe nos cuidados, porém, o número elevado de acompanhantes, a falta de estrutura física da unidade, sem a devida orientação a respeito de seus direitos, deveres, funcionamento e rotina da sala de urgência, dificulta o trabalho da equipe de enfermagem, gera conflitos e desentendimentos.

Foi a partir dessas dificuldades, pensando na inclusão do acompanhante como participante do cuidado ao usuário, premissas da política de humanização, que o grupo de orientação e acolhimento aos acompanhantes da sala de urgência foi criado com o objetivo de orientá-los.

A hospitalização, em geral, é vivida como um momento de 
vulnerabilidade física e emocional, que acomete tanto o usuário, quanto o seu acompanhante, o que na situação de urgência/emergência fica mais acentuado.

$\mathrm{Na}$ chegada do usuário e do familiar ao hospital, sentimentos e expectativas emergem, pois é um momento de tensão e de encontro com a realidade. Esse encontro pode desencadear conflitos, pois muitas vezes as expectativas idealizadas pela família são frustradas, além de outros aspectos referentes à rotina hospitalar que provocam a sensação de despersonalização, reações de hostilidade e revolta.

Para minimizar estas sensações e reações, um dos principais fatores apontados na literatura como facilitador é a comunicação (PENA; DIOGO, 2005; PINHO; KANTORSKI, 2006; SCHNEIDER et al., 2008).

Em função da alta demanda e rotatividade dos pacientes e acompanhantes na sala de urgência, não era possível, acolher, orientar e mesmo conhecer as necessidades da maioria dos pacientes e seus acompanhantes.

Foi a partir da reflexão junto aos diferentes atores, equipes de saúde, administrativa, usuários e acompanhantes que a intervenção e a proposta do grupo foi criada. Partiu-se da necessidade, tanto da instituição em informar e orientar os usuários, quanto dos usuários em mostrar quais são suas necessidades e dificuldades.

\section{OBJETIVO GERAL}

Orientar e acolher os acompanhantes sobre o funcionamento e rotina da Sala de Urgência (BOX).

\section{OBJETIVOS ESPECÍFICOS}

- Oferecer uma escuta qualificada às necessidades dos acompanhantes e se possível intervir nas suas relações, a fim de, assegurar o acesso à saúde;

- Apresentar de forma clara, objetiva e lúdica o funcionamento e rotina da sala de urgência. 
- Oferecer um espaço acolhedor e confortável, que respeite a privacidade da informação e que favoreça o encontro dos acompanhantes e os profissionais;

- Amenizar os conflitos gerados pela falta de informação e comunicação entre as equipes assistenciais e os acompanhantes;

- Articular com a equipe multidisciplinar de forma compartilhada os planos de ação e cuidado do paciente e sua família;

- Favorecer aos acompanhantes a posição de protagonista com relação a obter as informações de saúde de seu familiar e do cuidado junto a equipe médica e de enfermagem;.

- Analisar os problemas e dificuldades apresentadas pelos acompanhantes e levar como pauta para discutir no grupo de trabalho formado pela equipe multidisciplinar, coordenadores e diretores do hospital para melhorar ou aperfeiçoar os processos de trabalho;

- Estimular a comunicação entre gestores, trabalhadores e acompanhantes para construir processos de trabalho que produza mudanças nos modos de gerir e cuidar;

- Esclarecer as dúvidas dos acompanhantes.

\section{METODOLOGIA}

No dia 05 de abril de 2017, em reunião do Grupo de Trabalho Sala de Urgência, os representantes da equipe de enfermagem apresentaram de pauta as dificuldades no manejo dos acompanhantes, principalmente na Sala de Urgência - BOX/Ortopedia.

Em discussão de grupo, levantaram-se os seguintes questionamentos:

- Quais são as dificuldades da presença do acompanhante na Sala de Urgência?

- Quais são as dificuldades apontadas pelos acompanhantes referentes à Sala de Urgência?

- Qual o impacto da ausência do acompanhante na Sala de Urgência?

- Quais são os pontos positivos da presença do acompanhante na Sala de Urgência? 
A partir desses tópicos, acordou-se que profissionais da psicologia, serviço social e terapia ocupacional fariam levantamento das necessidades e sugestões dos atores envolvidos (acompanhantes e profissionais de diferentes áreas) e elaborariam apresentação para a próxima reunião, que ocorreu no dia 31 de maio de 2017. Para a colhermos tais necessidades foi utilizada a entrevista não estruturada.

Nessa reunião do dia 31 de maio de 2017, nova discussão foi realizada a partir dos dados apresentados. Foram pensados planos de ação para algumas propostas, dentre elas a elaboração de um grupo de orientação voltado para os acompanhantes da Sala de Urgência.

Desde julho de 2017 o grupo de acompanhantes da sala de urgência (BOX) acontece três vezes na semana em dias alternados (segundas, quartas e sextas), sendo que em cada dia a coordenação do grupo é responsabilidade de diferentes profissionais da equipe multiprofissional e geralmente duas categorias profissionais atuam em conjunto. Às segundas - feiras o grupo é realizado por profissionais da Terapia Ocupacional, às terças-feiras por profissionais da Psicologia e Nutrição e às sextas-feiras por profissionais do Serviço Social e Enfermagem.

As funções do coordenador responsável são: organizar espaço para realização do grupo; convocar os acompanhantes para participar; criar rapport (ligação, empatia) com os participantes; realizar as orientações conforme acordado; sanar dúvidas na medida do possível. Apresentar os profissionais, criando vínculos e segurança em relação à equipe de cuidados ao paciente

O local de realização do grupo pode ser variado, dependendo da disponibilidade de salas na instituição e também do número de acompanhantes que participarão do encontro.

A duração deste grupo é de aproximadamente 1 hora a cada encontro, sendo que cerca de 20 minutos são destinados ao levantamento dos acompanhantes presentes e ao convite a todos os acompanhantes para a participação no grupo. O restante do tempo destina-se a realização do grupo em si.

O levantamento dos acompanhantes presentes na Sala de Urgência é realizado através de informações disponíveis no sistema eletrônico utilizado no complexo do HCFMRP - USP, o profissional que será o coordenador do grupo 
no dia pesquisa neste sistema quais os pacientes que estão na Sala de Urgência possuem acompanhantes.

Após a identificação dos acompanhantes presentes no dia é realizado o convite a todos, sendo que a participação é livre, o próprio acompanhante decide sobre sua presença ou não no grupo. Em alguns casos há restrições quanto ao paciente ficar por algum tempo sem o acompanhante, como por exemplo, paciente tenha risco de queda ou demonstre agitação, nestas situações o acompanhante permanece ao lado do paciente impossibilitando sua participação no grupo.

Realizado o convite, os acompanhantes que participarão são encaminhados para o local no qual acontecerá o encontro.

O grupo inicia-se com a apresentação dos coordenadores e em seguida dos acompanhantes presentes e qual sua relação com 0 paciente. $O$ coordenador questiona quais os pacientes que já passaram por atendimento na Unidade de Emergência e quais se encontram pela primeira vez neste local e em seguida inicia as orientações.

As orientações são transmitidas de acordo com um roteiro preestabelecido, sendo opcional o uso de recursos visuais para ilustrar a apresentação. Foram desenvolvidos cartazes para apresentação destas informações por profissionais do serviço de terapia ocupacional da UE, estando o uso opcional ao condutor do grupo.

As informações transmitidas neste encontro foram selecionadas após levantamento com todas as equipes envolvidas na recepção e contato com os acompanhantes, a fim da identificação de possíveis dificuldades e estratégias para redução de conflitos.

Os acompanhantes são estimulados a esclarecer dúvidas sobre os tópicos apresentados e a caso tenham outras dúvidas durante a permanência na instituição são orientados a esclarecê-las com os profissionais da equipe.

Finalizado o grupo, os acompanhantes são novamente encaminhados a Sala de Urgência.

O profissional que coordenou o encontro deve ainda preencher uma planilha com informações sobre o número de pacientes internados na Sala de Urgência, número de acompanhantes presentes, quantos participaram do grupo, entre outras. 
Além disso, o profissional registra a participação do acompanhante através da evolução no prontuário eletrônico do paciente.

Informações relevantes que os acompanhantes expõem ao grupo como sugestões, queixas e elogios são apresentados à equipe de grupo de trabalho da Sala de Urgência para analisarem melhorias em prol aos acompanhantes, pacientes e colaboradores.

\section{RESULTADOS}

Depoimentos. 2018

Tabela1. Relatos de acompanhantes e profissionais durante a vivência do Grupo da Sala de Urgência e Sugestões

\begin{tabular}{|l|l|}
\hline № & Relatos \\
\hline 1 & $\begin{array}{l}\text { "Se eu soubesse dessas informações quando eu vim com a minha filha } \\
\text { que ficou internada, não teria tido problemas quando soube que eu não } \\
\text { poderia ficar de acompanhante quando ela saiu da SU para a } \\
\text { Enfermaria. Muito bom esse grupo."Nora de paciente A.A. P. }\end{array}$ \\
\hline 2 & "Graças a Deus temos esse HC!" Tia de paciente P. \\
\hline 3 & "O leite não vem tampado, caiu sujeira." \\
\hline 4 & Sugestão:Oferta de café durante o grupo. Marido de paciente S. \\
\hline 5 & $\begin{array}{l}\text { "Colocar cartazes na lanchonete, placas de advertência e folhetos de } \\
\text { informação para acompanhantes, em relação a proibição de entrada de } \\
\text { alimentos no hospital." }\end{array}$ \\
\hline 6 & $\begin{array}{l}\text { "Quando o paciente for transferido de ambulância, ter menos pessoas } \\
\text { dentro da mesma." }\end{array}$ \\
\hline 7 & $\begin{array}{l}\text { "Comunicação mais clara entre equipe e acompanhantes em relação a } \\
\text { quem ministra a medicação do paciente." }\end{array}$ \\
\hline 8 & $\begin{array}{l}\text { "Deveriam ter mais banheiros para os acompanhantes, geralmente } \\
\text { estão ocupados ou muito sujos. Cada andar deveria ter um banheiro } \\
\text { para acompanhantes." }\end{array}$ \\
\hline 9 & "Cadeiras mais confortáveis para os acompanhantes." \\
\hline 10 & $\begin{array}{l}\text { "Deveriam ter mais banheiros para os acompanhantes, geralmente } \\
\text { estão ocupados ou muito sujos. Cada andar deveria ter um banheiro } \\
\text { para acompanhantes." }\end{array}$ \\
\hline 11 & "Cadeiras mais confortáveis para os acompanhantes." \\
\hline
\end{tabular}




\begin{tabular}{|l|l|}
\hline 12 & $\begin{array}{l}\text { "Chão frio para os acompanhantes dormirem e a cadeira é } \\
\text { desconfortável. Não tem cobertor para os acompanhantes em caso de } \\
\text { esquecimento." }\end{array}$ \\
\hline 13 & $\begin{array}{l}\text { "Luzes dos banheiros dos pacientes deveriam estar em altura mais } \\
\text { acessível (1,70m). Pois as pessoas não costumam olhar para o teto." }\end{array}$ \\
\hline 14 & $\begin{array}{l}\text { "Precisa-se de ganchos/cabides para pendurar roupas nos banheiros } \\
\text { dos pacientes." }\end{array}$ \\
\hline 15 & $\begin{array}{l}\text { Cuidadores relatam não conseguir dormir devido a cadeiras } \\
\text { desconfortáveis, barulho e falta de familiares para revezar os cuidados. }\end{array}$ \\
\hline 16 & $\begin{array}{l}\text { Dúvidas e angústias sobre "O que será depois?", seja de uma cirurgia } \\
\text { ou encaminhamento para outro hospital. }\end{array}$ \\
\hline 17 & Banheiro dos acompanhantes sujo e com descarga quebrada. \\
\hline 18 & Espera de quatro dias aguardando leito. \\
\hline 19 & Acompanhantes enfrentam o frio de madrugada. \\
\hline 20 & Cadeira desconfortável para os acompanhantes. \\
\hline 21 & $\begin{array}{l}\text { Auxílio no banho, pela equipe de enfermagem, quando o paciente } \\
\text { encontra-se com limitações físicas. }\end{array}$ \\
\hline 22 & Transporte para U.E. com o SAMU. \\
\hline
\end{tabular}

Tabela 2. Dificuldades observadas para a confecção grupo pelo profissional da equipe multiprofissional em2018.

\begin{tabular}{|c|c|}
\hline 1 & $\begin{array}{l}\text { Número de acompanhante superior ao limite da sala destinada a este } \\
\text { fim }\end{array}$ \\
\hline 2 & $\begin{array}{l}\text { Paciente agitado, inviabilizado a saída do acompanhante por risco de } \\
\text { queda }\end{array}$ \\
\hline 3 & Médico passando visita no horário do agendamento do grupo \\
\hline 4 & Acompanhante auxiliando no banho do paciente \\
\hline 5 & Acompanhante auxiliando no cuidado de outro paciente idoso \\
\hline 6 & Horário de Troca de acompanhante \\
\hline 7 & Cancelamento do grupo por atendimento de urgência e óbito \\
\hline 8 & $\begin{array}{l}\text { Acompanhante se nega devido a relato de espera por paciente em } \\
\text { exame }\end{array}$ \\
\hline
\end{tabular}




\begin{tabular}{|l|l|}
\hline 9 & Paciente portador de deficiência física ou mental \\
\hline 10 & Acompanhante não encontrado após convite \\
\hline 11 & Acompanhante se retirou para fumar \\
\hline 12 & Paciente sendo transferido para Campus e ou Alta \\
\hline 13 & Paciente em exame \\
\hline 14 & $\begin{array}{l}\text { Paciente aguardando transferência e acompanhante inseguro de sair } \\
\text { próximo de mesmo }\end{array}$ \\
\hline 15 & Convocação médica \\
\hline
\end{tabular}

* Escolta não pode participou

Gráfico 1. Dados coletados 2으. Sem. 2017 à 1 Sem. 2018

DADOS COLETADOS

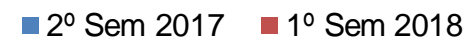
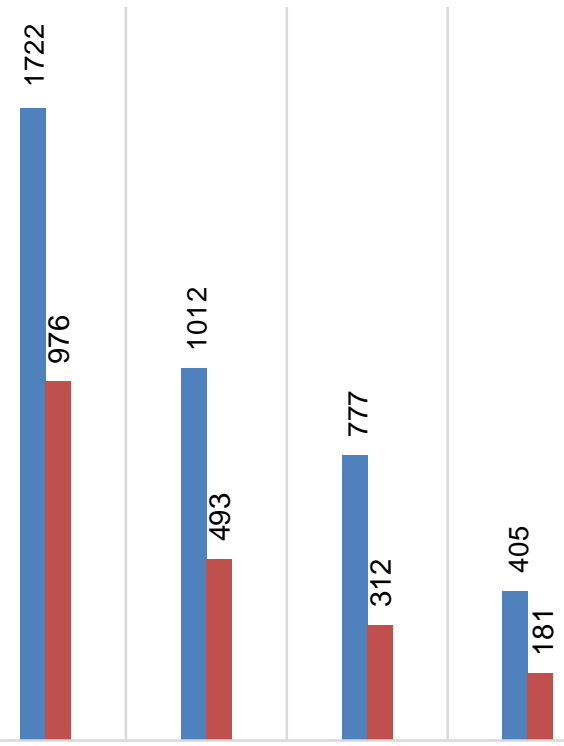

$\stackrel{\infty}{\llcorner m}$
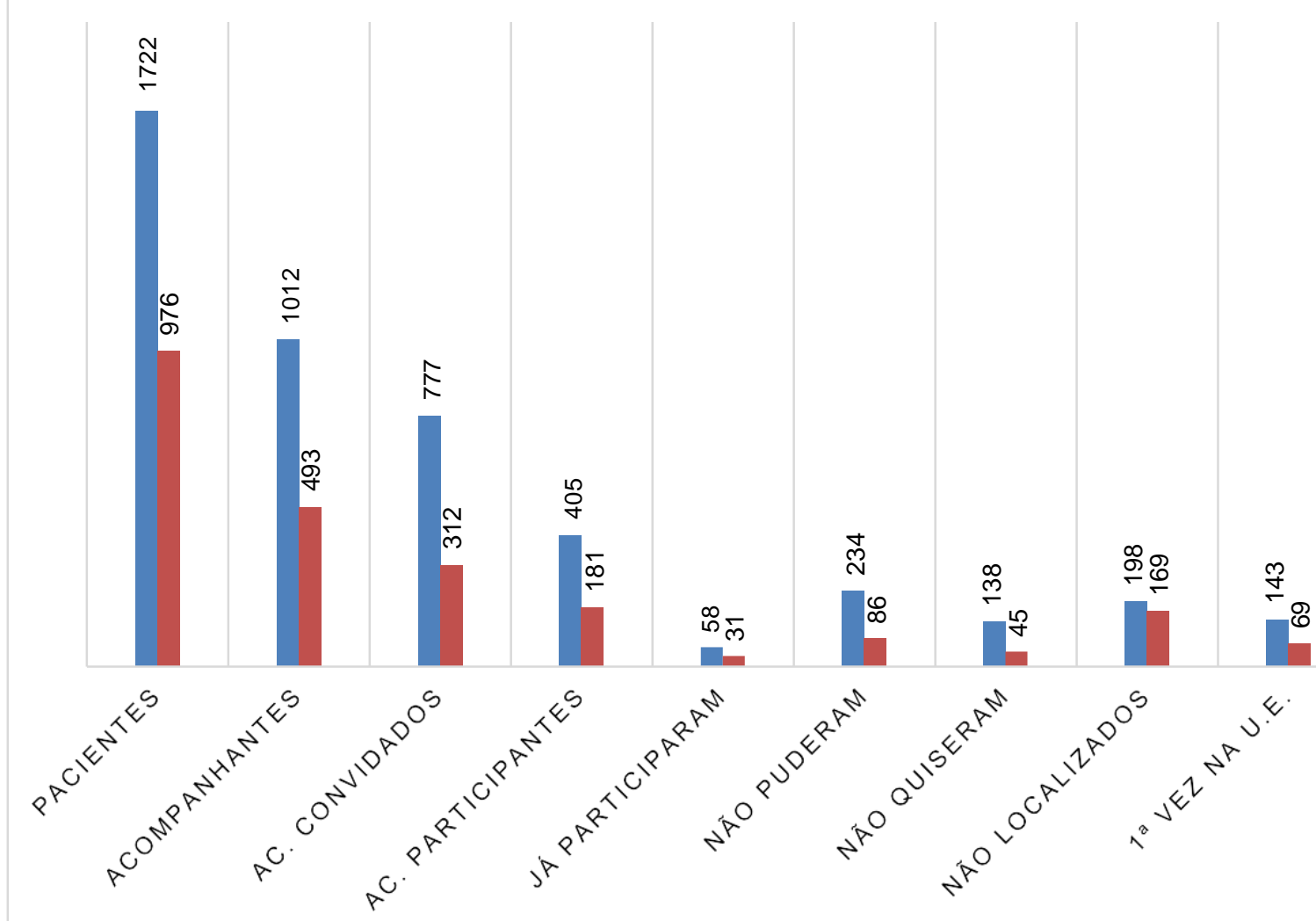
Gráfico 2. Frequência relativa dos dados coletados no $1^{\circ}$ semestre de 2018

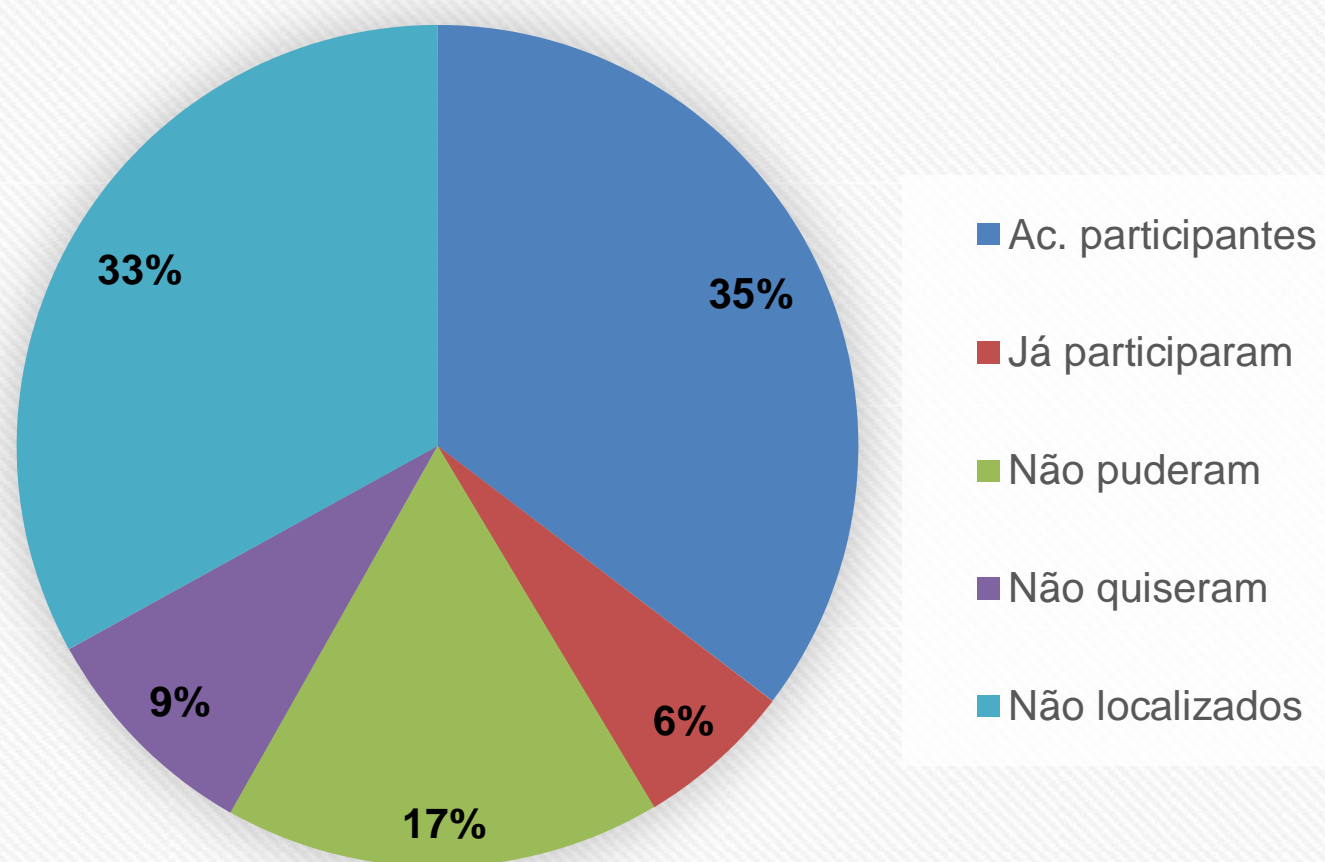

Gráfico 3. Frequência relativa Ac. participantes/Ac. convidados 30 Trim. 2017 à 2우 Trim. 2018

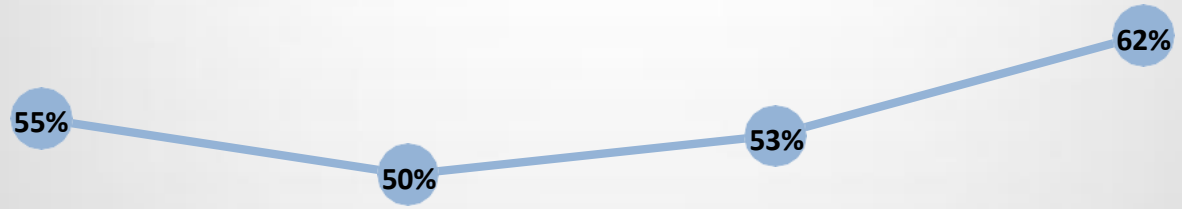


Gráfico 4. Frequência relativa dos dados coletados de Julho/17 à Julho/18

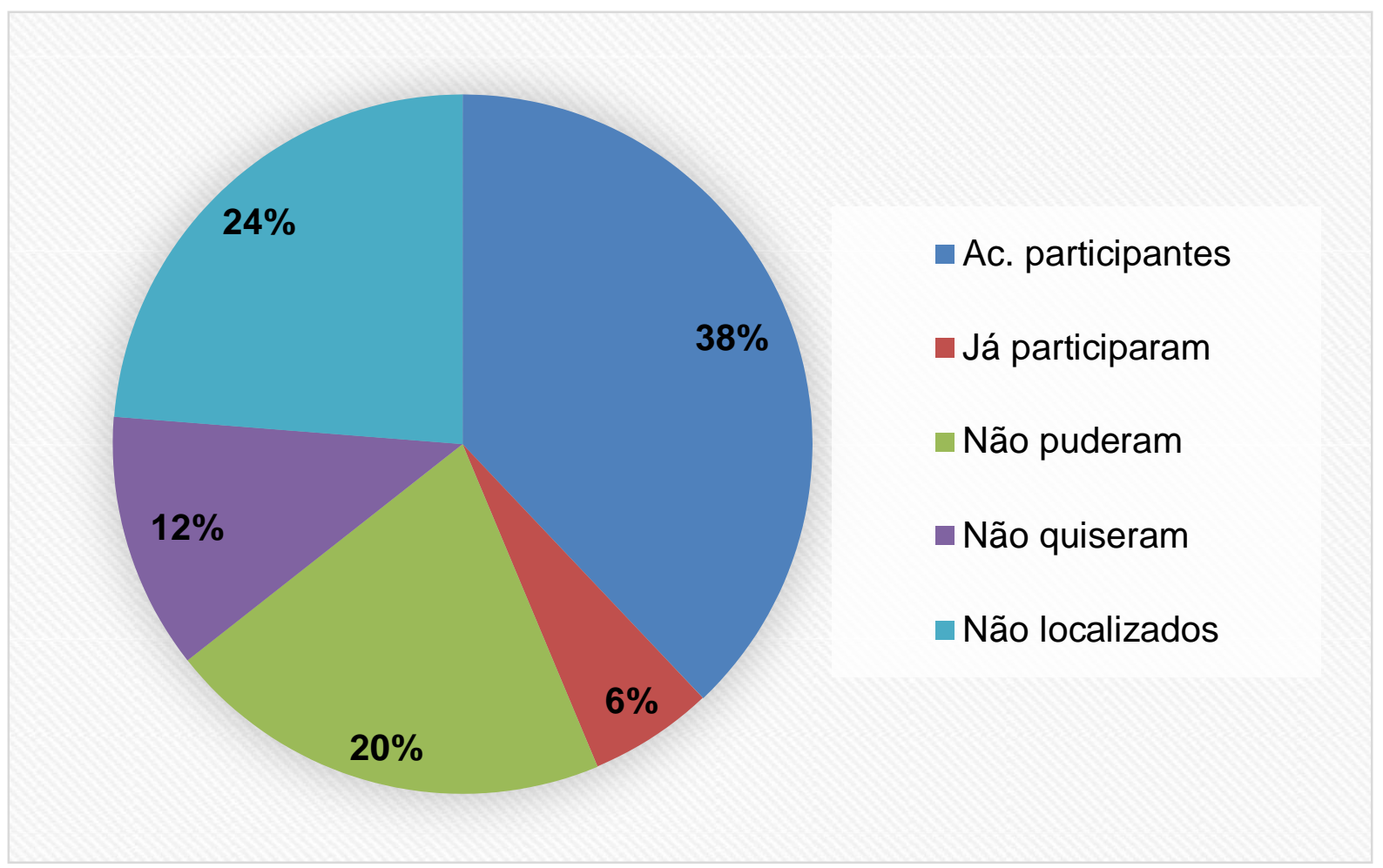

A Política Nacional de Humanização (PNH) existe desde 2003 para efetivar os princípios do SUS no cotidiano das práticas de atenção e gestão, qualificando a saúde pública no Brasil e incentivando trocas solidárias entre gestores, trabalhadores e usuários. A humanização é a valorização dos usuários, trabalhadores e gestores no processo de produção de saúde. Valorizar os sujeitos é oportunizar uma maior autonomia, a ampliação da sua capacidade de transformar a realidade em que vivem, através da responsabilidade compartilhada, da criação de vínculos solidários, da participação coletiva nos processos de gestão e de produção de saúde (Brasil, 2018).

Como política, a Humanização deve, portanto, traduzir princípios e modos de operar no conjunto das relações entre profissionais e usuários, entre os diferentes profissionais, entre as diversas unidades e serviços de saúde e entre as instâncias que constituem o SUS. O confronto de ideias, o planejamento, os mecanismos de decisão, as estratégias de implementação e de avaliação (BRASIL, 2004 p.7; Kaminski, 2011). 
Em julho de 2017, em virtude das características existentes no atendimento em urgência, após discussões em grupos de trabalhos surgiu por demanda dos próprios profissionais de saúde, criar o Grupo de Orientações aos Acompanhantes da

Sala de Urgência, visando o acolhimento, diminuição de angústias, otimização do processo de trabalho e auxiliar o acompanhante para se transformar um autor no processo de cuidado.

O Acompanhante é um representante da rede social da pessoa internada que a acompanha durante toda sua permanência nos ambientes de assistência à saúde $\mathrm{O}$ ambiente hospitalar pode ser um espaço de construção de autonomia e do autocuidado (BRASIL, 2007).

O período em que o acompanhante permanece no hospital também pode ser considerado uma fase de aprendizagem para este, que provavelmente será o cuidador quando o paciente receber alta. Como consequência, este período facilitará o trabalho das unidades básicas de saúde em seu trabalho à domicílio com este paciente (Kaminski, 2011).

A função do acompanhante dentro do hospital ainda é nebulosa para a equipe de saúde que acaba o transformando em inimigo durante o processo de hospitalização do paciente. Este distanciamento gerado pela falta de informação e pelo pré-conceito da equipe de saúde promove a doença relacional entre paciente/acompanhante e equipe. A ansiedade, produto desta relação doente é absorvida pelo paciente, resultando na dificuldade de adesão ao tratamento e aumento do período de hospitalização(Kaminski, 2011).

Ocorreu a identificação do cenário existente na urgência e das dificuldades encontradas pelo profissional da Equipe Multiprofissional no exercício de orientações em grupo, bem como o relato da percepção do acompanhante referente a ambiência, experiência evidenciada e críticas construtivas (Tabelas 1 e 2 ).

O número de grupos efetuados em 2018 em comparação ao ano de 2017 (Gráfico 1) apresentou uma queda em virtude da redução do número de profissional disponíveis para esta atividade em decorrência de período de férias, afastamento por licença saúde, não reposição de vagas e acúmulo de outras atribuições. No entanto, houve um aumento no decorrer do segundo 
trimestre do ano de 2018 no número de participantes atingindo 62\% dos acompanhantes convidados (Gráfico 3). Esse aumento se deve ao amadurecimento da linha de cuidado dos profissionais envolvidos, de estabelecimento do fluxograma de atendimento, envolvimento da equipe médica principalmente dos residentes sendo efetuadaestratégia em relação a divulgação de informação técnica aos acompanhantes e solicitações de exames aos pacientes.

Em relação aos acompanhantes que não quiseram participar, não puderam e não foram localizados (Gráficos 2 e 4), pode-se inferir que a ambiência influenciou na escolha de permanecer ao lado do paciente, por se tratar de macas dispostas em box, receio que o mesmo se agitasse e houvesse queda, faixa etária de adolescente não se manifestar segura em se ausentar de seu familiar, troca de acompanhantes no horário da execução do grupo, além de acompanhamento do paciente em exames. O acompanhante que já participou em algum momento do grupo ficava a critério próprio se desejava participar em um novo evento.

Durante a execução do grupo era transmitido aos participantes norma do serviço, informes, esclarecido dúvidas diversas e aberto para um diálogo de forma que ocorresse a escuta das sugestões e necessidades dos acompanhantes.

No decorrer de um ano, pode-se observar a mudança do papel do acompanhante, com a diminuição de conflitos entre a equipe de assistência, o mesmo apoderando -se de seus deveres e direitos, auxiliando na assistência ao seu familiar. Muitas das reflexões exercidas pelo grupo, tornou-se plano de ação e oportunidade de melhoria para a gestão.

Com o apoio do gestor, foram já tomadas medidas corretivas coma não dispensação de grande volume de recursos financeiros, mas com pequenas mudanças no processo. Ex: identificação das macas, implantação de kanban, oferta de café, convecção de painéis informativos e ordens de manutenção de serviço, aviso luminoso para o banheiro em uso, aquisição de cadeiras para acompanhantes, explicação do motivo porque o ambiente deve permanecer com ar condicionado ligado, reformulação do fluxo de higienização de banheiros, aquisição de carrinhos para dispensação exclusiva de restos de alimentos e disposição de bandejas, criação da política de visitantes e 
acompanhantes. Outras medidas que necessitam de maior recurso financeiro estão sendo estudadas, assim como reforma física e também disponibilização de um número maior de banheiros.

Para a Equipe atuante na Sala de Urgência a implantação deste modelo de grupo foi positiva, e os resultados foram compartilhados em outros grupos de trabalho, como exemplo o das enfermarias, hoje é elaborada a ampliação desde modelo de acordo com a particularidade de cada clínica.

\section{REFERÊNCIA BIBLIOGRAFICA}

BRASIL. MINISTÉRIO DA SAÚDE. Política Nacional de Humanização. pag 6 e 7. $1^{\text {a }}$ edição. Brasília, 2013. Disponível em. http://bvsms.saude.gov.br/bvs/publicacoes/politica nacional humanizacao pnh folheto.pdf. Acesso em 23.10.18 as 07:00.

BRASIL. MINISTÉRIO DA SAÚDE. Secretaria de Atenção à Saúde. Núcleo Técnico da Política Nacional de Humanização. HumanizaSUS: visita aberta e direito a acompanhante / Ministério da Saúde, Secretaria de Atenção à Saúde, Núcleo Técnico da Política Nacional de Humanização. - 2. ed. - Brasília: Ministério da Saúde, 2007. 32 p.: il. - (Série B. Textos Básicos de Saúde). Disponível em:http://bvsms.saude.gov.br/bvs/publicacoes/visita acompanhante 2ed.pdf 10/10/2018.

BRASIL. POLÍTICA NACIONAL DE HUMANIZAÇÃO. HumanizaSUS. 2018 Disponível em: <http://portalms.saude.gov.br/acoes-e-programas/politicanacional-de-saude-bucal/legislacao/693-acoes-e-programas/40038humanizasus $>$ 07/09/2018.

. MINISTÉRIO DA SAÚDE. Secretaria de Atenção à Saúde. Núcleo Técnico da Política Nacional de Humanização.HumanizaSUS: Política Nacional de Humanização: a humanização como eixo norteador das práticas de atenção e gestão em todas as instâncias do SUS / Ministério da Saúde, SecretariaExecutiva, Núcleo Técnico da Política Nacional de Humanização. - Brasília: Ministério da Saúde, 2004.

KAMINSKI FILHO, Marcos Vinicius. Avaliação da satisfação dos acompanhantes usuários do SUS em um Hospital Geral/ Marcos Vinicius Kaminski Filho. Curitiba:2011, 24 f. 24 Disponível em: https://www.acervodigital.ufpr.br/bitstream/handle/1884/54417/R\%20$\% 20 \mathrm{E} \% 20-$

\%20MARCOS\%20VINICIUS\%20KAMINSKI\%20FILHO.pdf?sequence=1

PENA, S. B.; DIOGO, M. J. D. E. Fatores que favorecem a participação do acompanhante no cuidado do idoso hospitalizado. Rev. Latinoam. Enferm., v. 13, n. 5, p. 663-669, set.-out. 2005. 
PINHO, L. B.; KANTORSKI, L. P. Condições de atendimento na unidade de emergência: um estudo qualitativo com famílias de pacientes. Fam. Saúde Desenv., Curitiba, v. 8, n. 3, p. 223-232, set.-dez. 2006.

SCHNEIDER, D. G.; MANSCHEIN, A. M. M.; AUSEN, M. A. B.; MARTINS, J. J.; ALBUQUERQUE, G. L. Acolhimento ao paciente e família na unidade coronariana.Texto Contexto Enferm., Florianópolis, v. 17,n. 1, p. 81-89, jan.mar. 2008.

SILVA, HELLEN T. P. L. O acolhimento ao familiar acompanhante do idoso em situação de urgência/emergência / Hellen Taciane Paschoalotto Leite Silva; orientadora Sueli Marques. - Dissertação (Mestrado) - Universidade de São Paulo, 2010. 
APÊNDICE B - CARTAZES DO GRUPO DE ACOLHIMENTO DA SALA DE URGÊNCIA

Material elaborado por: Luana Croscrato e Francine de Castro Alves Victal, 2017 Serviço de Terapia Ocupacional da Ocupacional da Unidade de Emergência, em colaboração da equipe multiprofissional.
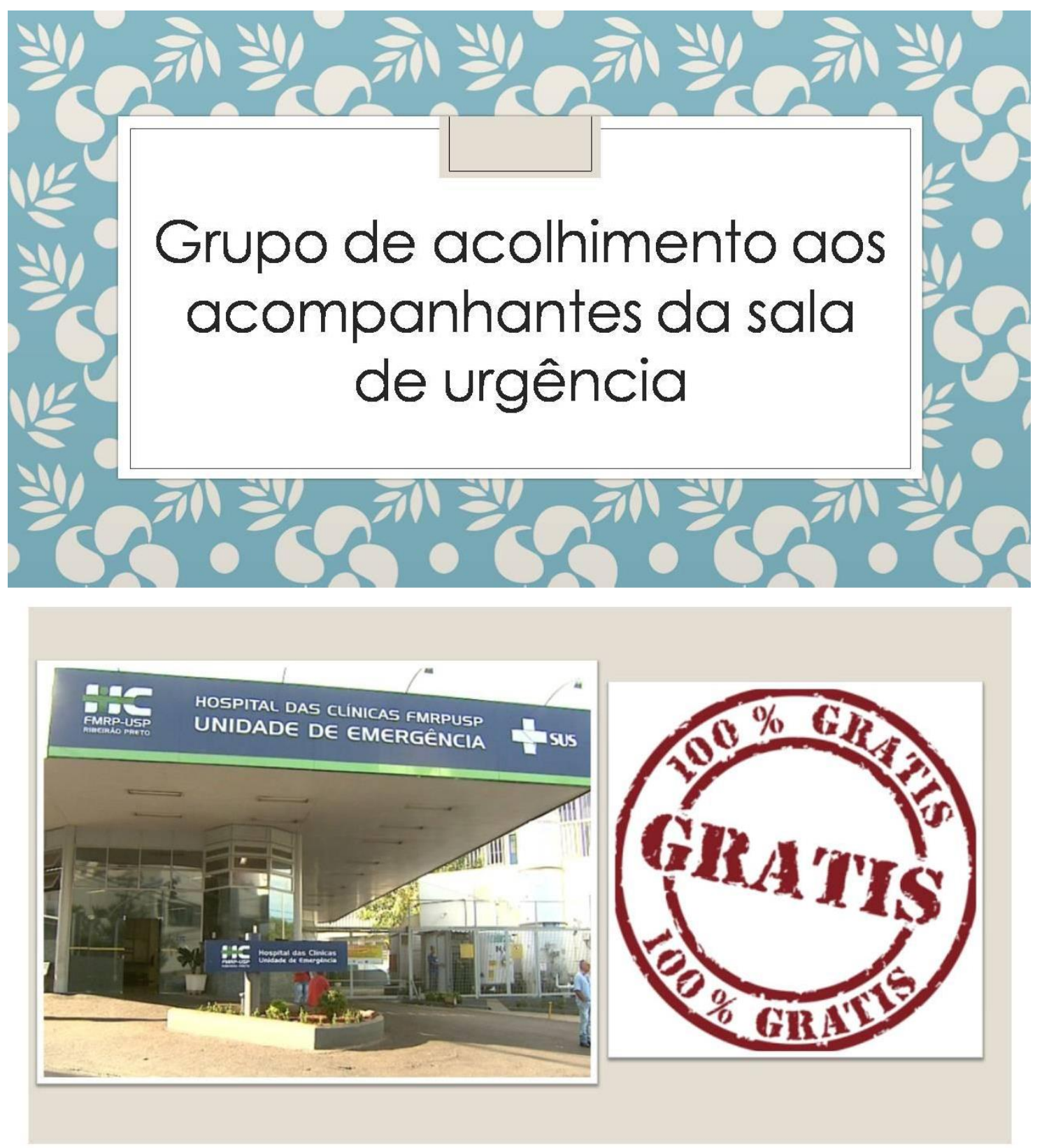


\section{Entrada do paciente}
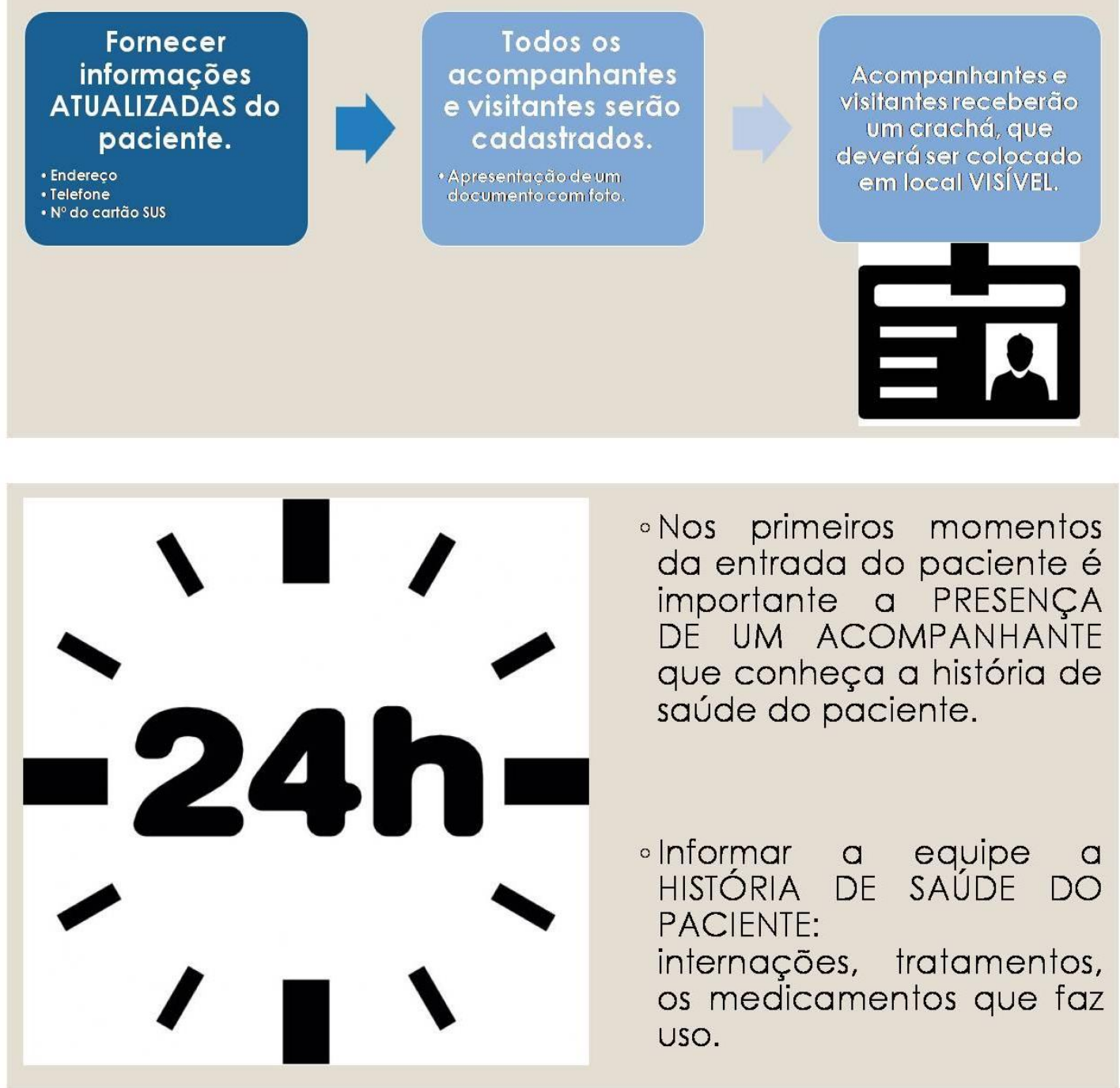


\section{Acompanhante}

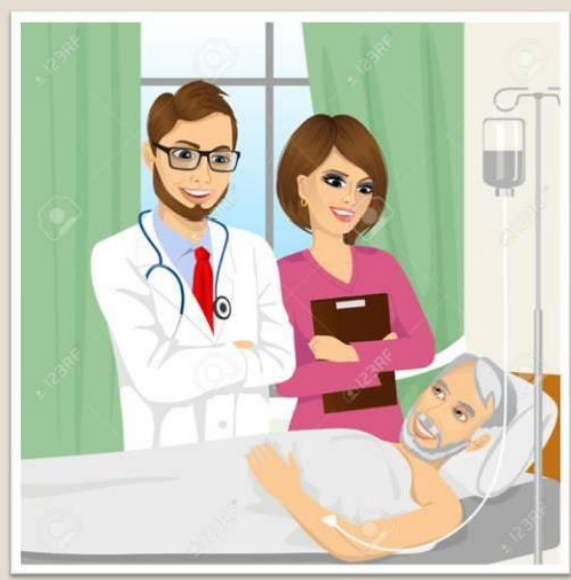

- Na sala de Urgência o paciente tem direito a acompanhante lem outros locais, pode ocorrer alteraçōes).

- Presença da família é de grande importância, deve-se evitar trazer conflitos.

\section{Acompanhante}

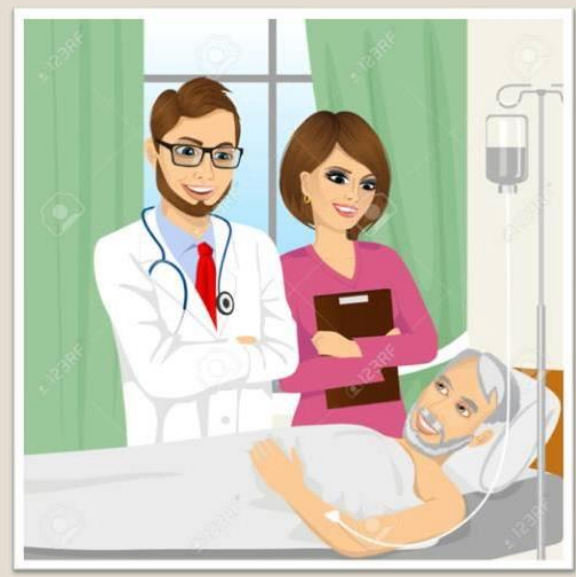

- Deve - se procurar estabelecer com a família um responsável para falar com a equipe médica.

- Atendimento médico ao acompanhante: somente em caso de emergência. 


\section{Horário de Visita}

\section{Local \\ Horário}

Sala de Urgência $13 \mathrm{~h}$ às $21 \mathrm{~h}$. (BOX e Ortopedia)

Revezamento de 1 pessoa por vez.

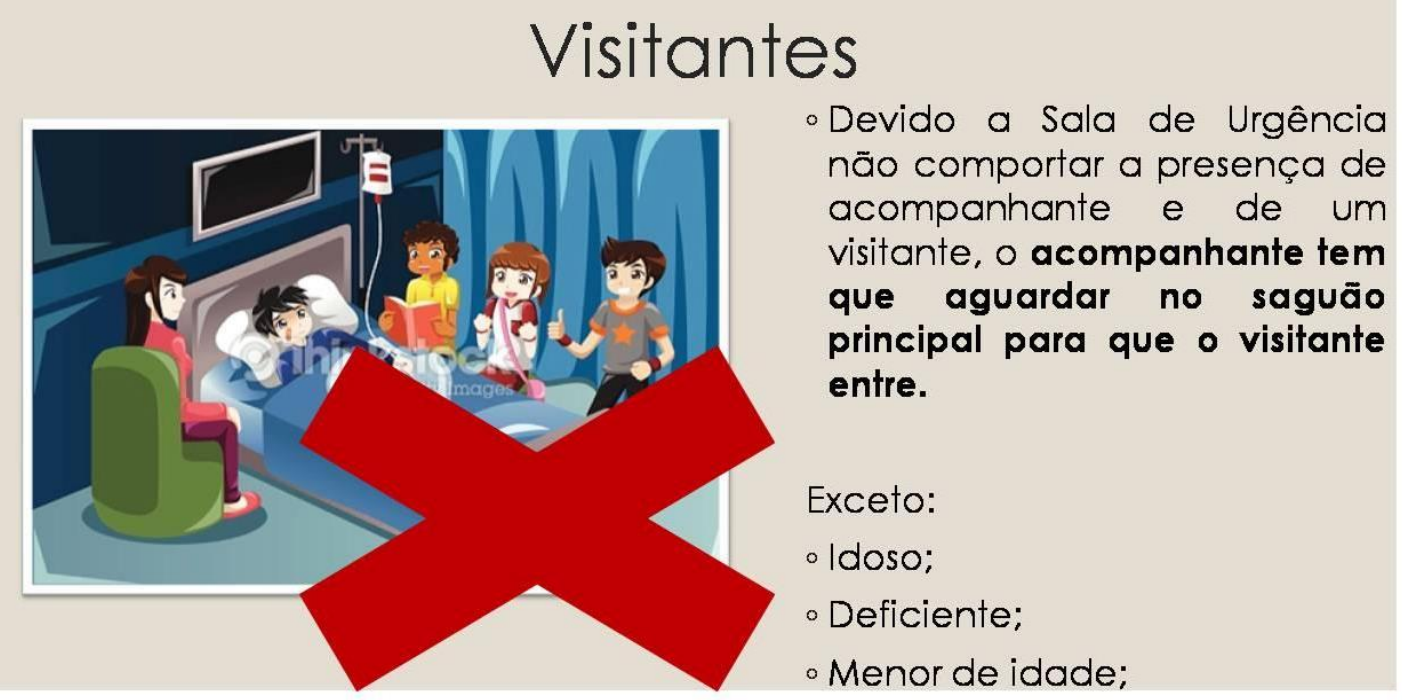




\section{Outras Informações}

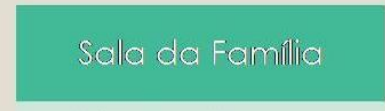

- Visita familiar.

- É necessário avisar a equipe de enfermagem.

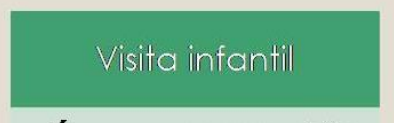

- É necessário procurar o serviço de psicologia para avaliação.

- A visita é autorizada a partir de 12 anos.

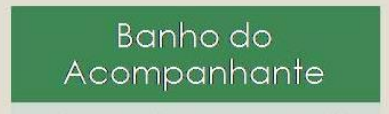

- Banheiro ao lado da sala de espera. - É responsabilidade do acompanhante levar os itens de higiene.

\section{Alimentação}

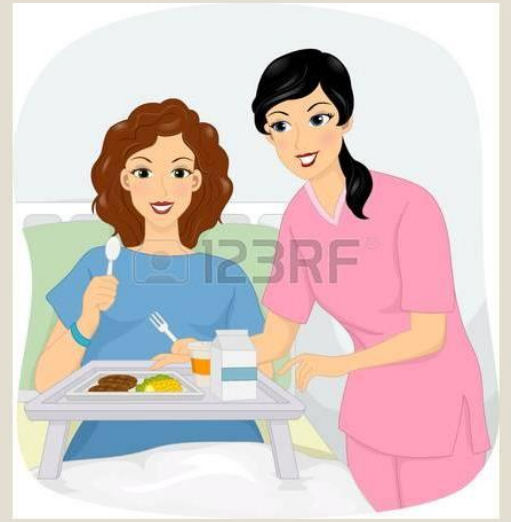

- Quando o paciente chega na unidade ele deve permanecer em jejum (alimentos e líquidos) até ser liberado por escrito pelo médico.

- Todas as refeições para o paciente são fornecidas pelo hospital. 


\section{Alimentação}

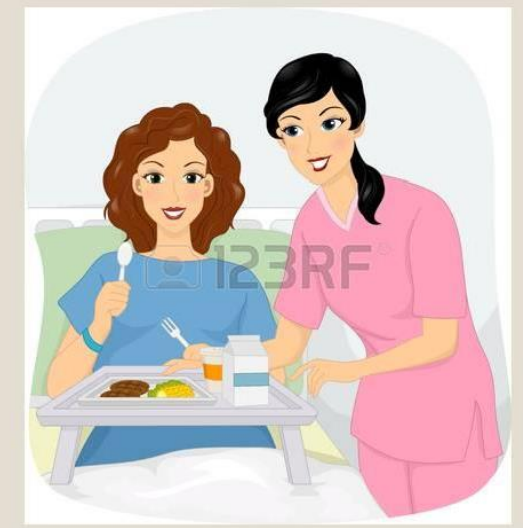

- Não ofereça alimento e/ou bebida ao paciente sem autorização.

- O acompanhante na sala de urgência têm direito a refeição (café da manhā, almoço e jantar).

\section{Medicamento}
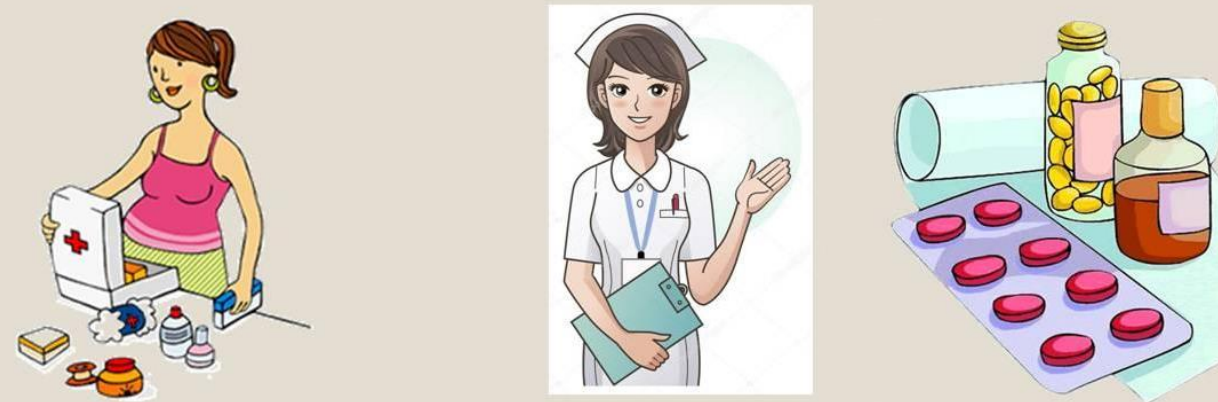

- Traga uma lista de casa e informe ao médico.

- Não dê nenhum medicamento ao paciente sem orientação. 


\section{Sigilo e Privacidade}
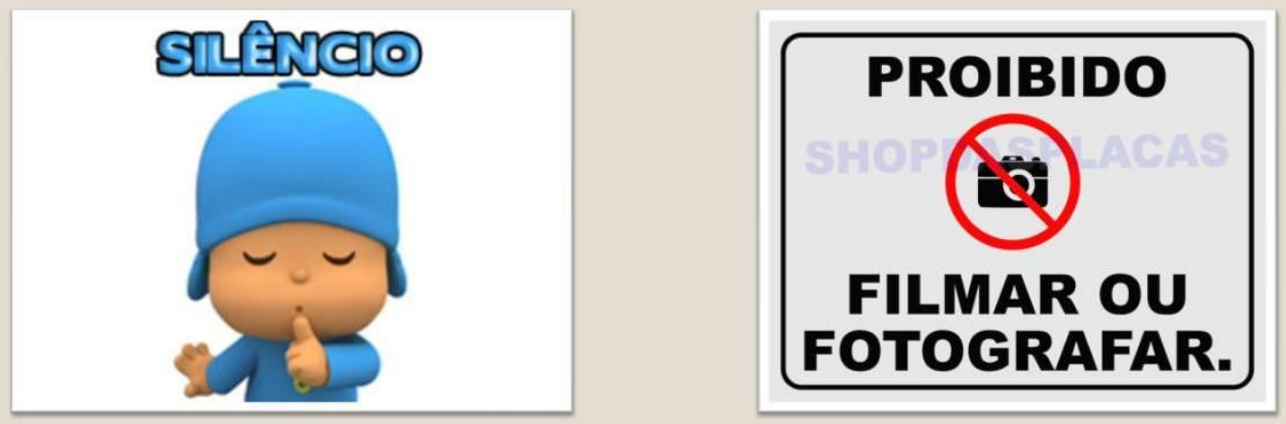

Assistência Religiosa

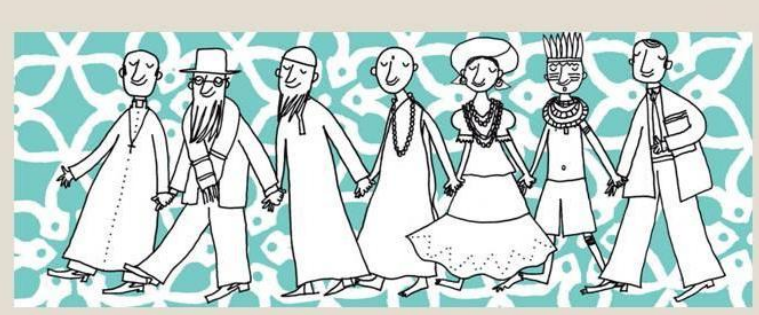

- O paciente ou sua família tem direito a assistência religiosa.

- É necessário comunicar a equipe de enfermagem ou o serviço social. 


\section{Direito à Informação}
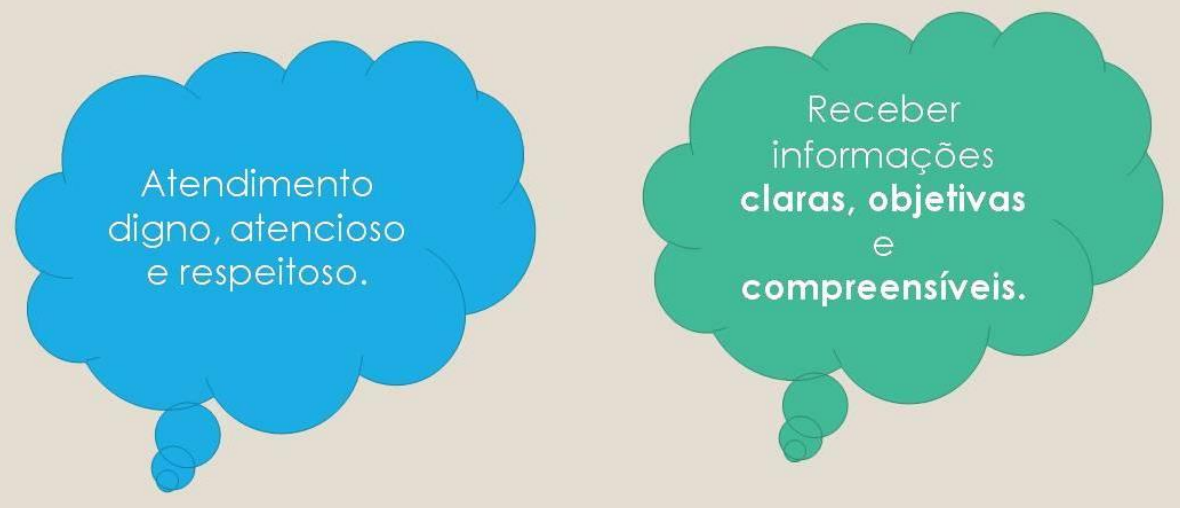

\section{Rotina - Manhã}

- Os pacientes são examinados pela equipe médica;

- Realização de alguns exames;

- É realizada a higiene do paciente.
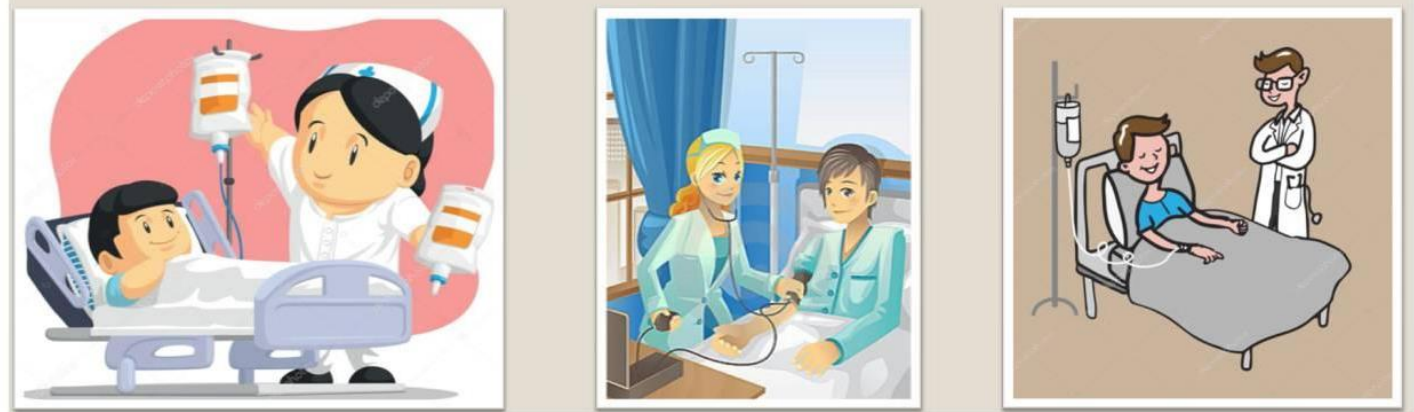


\section{Rotina - Tarde}

- Período em que o médico conversa com o acompanhante;

- Outros exames;

- Os cuidados da equipe de enfermagem ocorrem a todo momento.
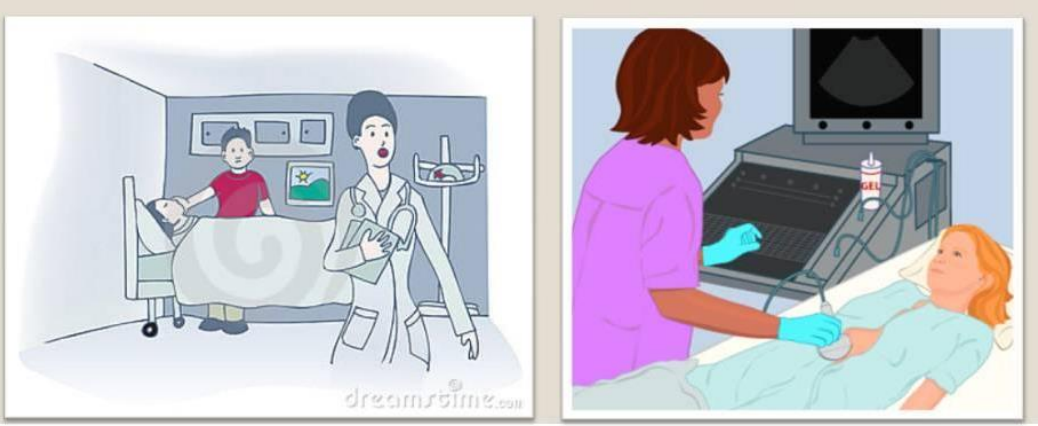

\section{Alta}
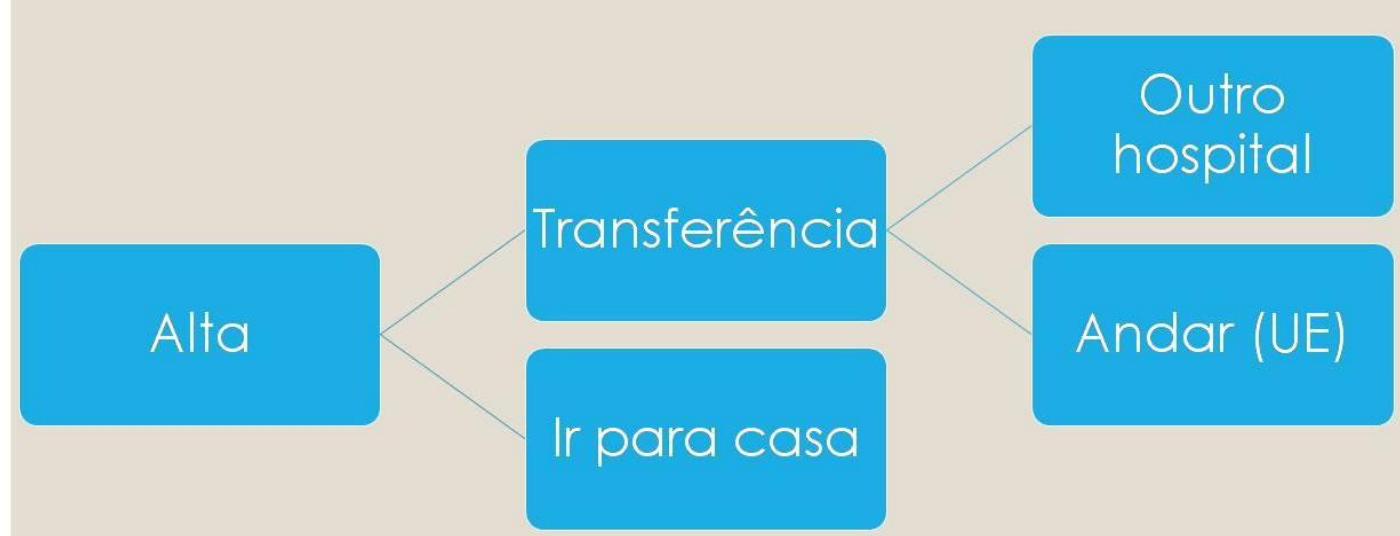


\section{Alta}

\section{- Checar os documentos:}

- Receita em 2 cópias (as duas com assinatura);

- Guia de contra-referência;

- Atestado médico;

- Devolução de exame e/ ou medicamento (caso você trouxe algum);

- DECLARAÇÃO para o acompanhante.

- Levar todos os seus pertences (travesseiro, roupa, calçado)

\section{- Transporte}

\section{Ouvidoria}

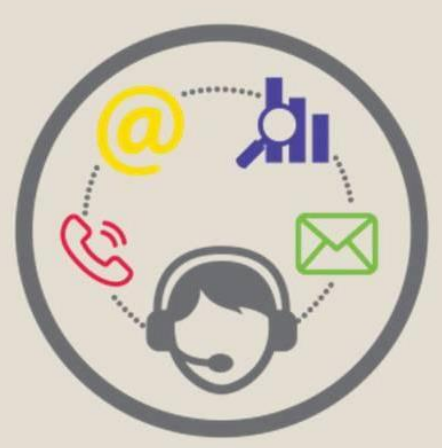

OUVIDORIA
- Pessoalmente: ao lado da cafeteria. (seg. a sex. $-7 \mathrm{~h}$ às $13 \mathrm{~h}$ ).

- Telefone: (16) 3602-1010 (seg. a sex. - $7 \mathrm{~h}$ às 13h).

- Papel: depositarnas umas, presentes em todos os andares.

- Email: ouvidoriaue@hcrp.usp.br 


\section{APÊNDICE C - TERMO DE CONSENTIMENTO LIVRE E ESCLARECIDO (TCLE)}

\section{TERMO DE CONSENTIMENTO LIVRE E ESCLARECIDO \\ (Conselho Nacional de Saúde, Resolução 466/12)}

\section{O Senhor(a)}

está sendo convidado a participar da pesquisa intitulada: "Avaliação da qualidade da comunicação entre a equipe de saúde e os usuários/acompanhantes na sala de urgência de um hospital terciário", na condição de voluntário, que será desenvolvida pela aluna de mestrado Francine de Castro Alves Victal, sob orientação do Prof. Dr. Carlos Henrique Miranda. O objetivo principal do trabalho é avaliar a qualidade da comunicação entre a equipe de saúde e os usuários/acompanhantes da sala de urgência da Unidade de Emergência do Hospital das Clínicas da Faculdade de Medicina de Ribeirão Preto e para isso a pesquisa pretende ser realizada em dois momentos:

1) Após as primeiras 12 horas de passagem pela sala de urgência será realizado um questionário e uma escala numérica contendo perguntas sobre a maneira como ocorre a comunicação na sala de urgências e as emoções vivenciadas neste momento.

2) Será realizado após a alta, depois de 2 meses será feito perguntas de uma escala relacionada ao estresse.

O senhor (a) terá toda a liberdade de recusar a participar da pesquisa ou a qualquer momento retirar-se da mesma, sem nenhum constrangimento. Os pesquisadores garantem a confidencialidade dos dados e manutenção do sigilo e da privacidade dos participantes da pesquisa durante todas as fases da pesquisa. O seu nome não será identificado no questionário, e será representado por códigos.

Este estudo não implicará em mudança no tratamento clínico oferecido ao usuário durante sua passagem na Unidade de Emergência. Este estudo considera a possibilidade de riscos mínimos, nenhum de ordem física, tais como, um possível constrangimento diante de perguntas do questionário, e o relacionado ao tempo que será gasto para o senhor (a) responder ao mesmo (aproximadamente 10 minutos). Esta 
entrevista será realizado sem prejudicar o andamento do tratamento proposto na sala de urgência.

A pesquisa não trará nenhum benefício direto aos participantes do estudo, no entanto poderá trazer benefícios futuros, principalmente em relação a qualidade da informação oferecida e na qualidade da comunicação dentro do sistema público de saúde.

Em caso de dúvida ou necessidade de esclarecimentos adicionais, você poderá entrar em contato com a pesquisadora Francine de Castro Alves Victal pelos telefones: (16) 981653816/ (16) 36021132, e-mail: fvictal@hcrp.usp.br ou pelo endereço: Praça Odair Fernandes, número 70, apto. 103, Ribeirão Preto - SP CEP 14026-591, ou ainda entrar em contato direto com o Comitê de Ética em Pesquisa do Hospital das Clínicas pelo telefone (16) 3602-2228.

DECLARO, portanto, que após devidamente esclarecido pelos pesquisadores e ter entendido o que foi explicado, consinto voluntariamente em participar desta pesquisa, confirmando este desejo através da assinatura abaixo em 2 (duas) vias, sendo que uma delas será entregue à mim.

Assinatura do voluntario

Nome por extenso:

Data:

Nome por extenso:

Data: 
APÊNDICE D - FORMULÁRIO SOCIODEMOGRÁFICO

Data:
Paciente:
Registro:
Cidade:
Sexo: -
Idade: $:$
Entrada: :
Especialidade: :
CID: P_:

Nome do Acompanhante:

Idade:

Sexo:

Parentesco com o paciente:

Cidade:

Estudou?

( ) Ensino fundamental

( ) Ensino médio

( ) Ensino superior

Trabalho:

Quando chegou aqui?

Telefone de contato: 
ANEXO 1 - RELATÓRIO PLANEJAMENTO ESTRATÉGICO

\author{
HOSPITAL DAS CLÍNICAS DA FMRP-USP \\ PLANEJAMENTO ESTRATÉGICO
}

Categoria: Urgência e Emergência

Objetivo Estratégico: Revisar processos de trabalho existentes e criação de novos processos

Ação: Criar Núcleo Integrado de Humanização

Resultados: O Grupo de Trabalho e Planejamento em Humanização iniciado desde novembro de 2015 com definição de Regimento Interno e implantação do Centro Integrado de Humanização contendo membros de diversas categorias profissionais e representatividade dos diferentes setores da Unidade de Emergência. Foram realizadas 26 reuniões com periodicidade quinzenal e duração de 90 minutos. Realizou-se desta forma, intervenções com base nas necessidades levantadas, bem como, discussões frente à demais demandas identificadas processualmente ao longo das ações. Seguem as atividades planejadas para 2017:

\begin{tabular}{|c|c|c|c|}
\hline Atividade & Status & Descrição & Ação \\
\hline $\begin{array}{c}\text { Construção do Plano } \\
\text { Institucional de Humanização } \\
\text { - PIH }\end{array}$ & Em andamento & $\begin{array}{l}\text { Construção de plano } \\
\text { de ação em } \\
\text { humanização da UE } \\
\text { para } 2017\end{array}$ & $\begin{array}{c}\text { Mapeamento de ações que } \\
\text { foram discutidas em grupos } \\
\text { de trabalho e em reuniões do } \\
\text { GTPH }\end{array}$ \\
\hline $\begin{array}{l}\text { Aplicação de Formulário de } \\
\text { Classificação de Ambiência, } \\
\text { de acordo com o tipo e a } \\
\text { complexidade do Serviço para } \\
\text { adequação do espaço físico }\end{array}$ & Em andamento & $\begin{array}{l}\text { Aplicação do } \\
\text { formulário conforme } \\
\text { previsto na Política } \\
\text { Estadual de } \\
\text { Humanização }\end{array}$ & $\begin{array}{l}\text { Espaço conforto/descanso } \\
\text { dos funcionários } \\
\text { Aplicação por setores } \\
\text { (iniciar na Sala de Urgência) }\end{array}$ \\
\hline $\begin{array}{l}\text { Acompanhamento, avaliação e } \\
\text { intervenção do indicador de } \\
\text { Pesquisa de Satisfação }\end{array}$ & Em andamento & $\begin{array}{c}\text { Acompanhar analisar } \\
\text { os indicadores da } \\
\text { pesquisa }\end{array}$ & $\begin{array}{l}\text { Organizar e aprimorar o } \\
\text { processo de trabalho - entrega } \\
\text { das fichas, preenchimento, } \\
\text { recolhimento, tabulação e } \\
\text { devolutiva aos setores. }\end{array}$ \\
\hline Projeto de Comunicação & Em andamento & $\begin{array}{c}\text { Melhorar a } \\
\text { comunicação e o } \\
\text { marketing interno da } \\
\text { UE }\end{array}$ & $\begin{array}{l}\text { Parceria no projeto de } \\
\text { extensão dos cursos de } \\
\text { Jornalismo e Publicidade da } \\
\text { Universidade Estácio de Sá. }\end{array}$ \\
\hline $\begin{array}{c}\text { Estruturar um Grupo de } \\
\text { Trabalho para intervenção em } \\
\text { Altas Qualificadas }\end{array}$ & Em andamento & $\begin{array}{l}\text { Alinhar os processos } \\
\text { de alta hospitalar nos } \\
\text { diferentes setores. }\end{array}$ & $\begin{array}{c}\text { Reuniões com equipes para } \\
\text { desenho dos processos de alta } \\
\text { por setores. }\end{array}$ \\
\hline
\end{tabular}




\begin{tabular}{|c|c|c|c|}
\hline $\begin{array}{c}\text { Desenvolver ações em } \\
\text { consonância com o } \\
\text { programa "Hospital Amigo do } \\
\text { Idoso" }\end{array}$ & Em andamento & $\begin{array}{l}\text { Realizar ações que } \\
\text { possam estar alinhadas } \\
\text { as propostas } \\
\text { preconizadas pelo } \\
\text { programa. Exemplo: } \\
\text { realizar oficina de } \\
\text { sensibilização como a } \\
\text { do HC Campus }\end{array}$ & $\begin{array}{l}\text { Visita técnica de capacitação } \\
\text { durante a oficina de } \\
\text { sensibilização; } \\
\text { Iniciar a participação nas } \\
\text { reuniões do programa junto } \\
\text { ao HC Campus }\end{array}$ \\
\hline Grupo da Psicanálise & Em andamento & $\begin{array}{l}\text { Oferecer espaços de } \\
\text { acolhimento e cuidado } \\
\text { em saúde } \\
\text { proporcionando a } \\
\text { reflexão da prática } \\
\text { profissional }\end{array}$ & $\begin{array}{l}\text { Reuniões com a Sociedade } \\
\text { Brasileira de Psicanálise para } \\
\text { alinhamento dos grupos }\end{array}$ \\
\hline Grupo do Voluntariado & Em andamento & $\begin{array}{c}\text { Construir plano de } \\
\text { ação envolvendo } \\
\text { voluntários para } \\
\text { diferentes atividades } \\
\text { na UE } \\
\end{array}$ & $\begin{array}{l}\text { Reuniões com o Voluntariado } \\
\text { de Ribeirão Preto para } \\
\text { alinhamento de ações }\end{array}$ \\
\hline $\begin{array}{c}\text { Ampliar o Projeto "Cinema na } \\
\text { Enfermaria" }\end{array}$ & Em andamento & $\begin{array}{c}\text { Realizar atividade de } \\
\text { cinema para a } \\
\text { enfermaria de } \\
\text { Psiquiatria }\end{array}$ & $\begin{array}{c}\text { Organização e } \\
\text { empoderamento das equipes } \\
\text { para desenvolvimento da } \\
\text { ação }\end{array}$ \\
\hline $\begin{array}{l}\text { Projeto de "Visita Ampliada } \\
\text { em UTI" }\end{array}$ & Em andamento & $\begin{array}{l}\text { Estudo Multicêntrico } \\
\text { que visa analisar os } \\
\text { reais benefícios da } \\
\text { visita ampliada na UTI }\end{array}$ & $\begin{array}{l}\text { Treinamento das equipes } \\
\text { multiprofissionais para o } \\
\text { desenvolvimento do projeto }\end{array}$ \\
\hline $\begin{array}{l}\text { Projeto do Acompanhante } \\
\text { Principal da Sala de Urgência }\end{array}$ & Em andamento & $\begin{array}{l}\text { Melhorar o fluxo de } \\
\text { informações entre } \\
\text { acompanhantes e } \\
\text { profissionais }\end{array}$ & $\begin{array}{l}\text { Grupo Multiprofissional de } \\
\text { Orientações }\end{array}$ \\
\hline $\begin{array}{l}\text { Estruturar espaço adequado } \\
\text { para os servidores da UE }\end{array}$ & Concluído & $\begin{array}{l}\text { Oferecer espaço de } \\
\text { descanso para os } \\
\text { funcionários em } \\
\text { especial nos intervalos } \\
\text { entre jornadas } \\
\end{array}$ & $\begin{array}{l}\text { Organização de espaço físico } \\
\text { com ênfase na ambiência }\end{array}$ \\
\hline Grupos de Trabalho & Concluído & $\begin{array}{l}\text { Conhecer e aprimorar } \\
\text { processos de trabalho }\end{array}$ & $\begin{array}{l}\text { Reuniões das equipes com } \\
\text { periodicidade definida }\end{array}$ \\
\hline $\begin{array}{c}\text { Estruturar o serviço de } \\
\text { Ouvidoria }\end{array}$ & Concluído & $\begin{array}{l}\text { Possibilitar canal de } \\
\text { comunicação entre } \\
\text { usuários e a instituição }\end{array}$ & $\begin{array}{l}\text { Organização de espaço físico } \\
\text { e nomeação de funcionário } \\
\text { específico para a função }\end{array}$ \\
\hline
\end{tabular}

Qual a situação atual da Ação:

(X) Concluída ( )Suspensa ( )Alterada ( )Cancelada

Núcleo não Formalizado oficialmente através de Portaria da Superintendência. 
Em Caso de Conclusão: O Centro Integrado teve como meta principal para a implementação desta Ação intervenções em consonância com as diretrizes da Política Nacional e Estadual de Humanização. No entanto, nota-se fragilidades comuns à serviços como o Hospital de Urgência e Emergência. Desta forma, apesar de estabelecer um plano de metas em vários momentos foi necessário alterar o desenvolvimento do mesmo. 
ANEXO 2 - OFÍCIO No1541/2017

HOSPITAL DAS CLIINICAS DA FACULDADE DE MEDICINA DE RIBEIRÃO PRETO DA UNIVERSIDADE DE SÃO PAULO

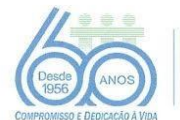

Ribeirão Preto, 24 de maio de 2017

Oficio $n^{\circ} 1541 / 2017$

CEP/MGV

Prezados Senhores,

O trabalho intitulado "AVALIAÇÃO DA QUALIDADE DA USUART A EQUIPE DE SAUDDE E OS USUAR TERCIARIO" , foi analisado pelo Comitê de Etica em Pesquisa em sua $450^{\mathrm{a}}$ Reunião Ordinária, realizada em 22/05/2017 e enquadrado na categoria: APROVADO, bem como o Termo de Consentimento Livre e Esclarecido, de acordo com o Processo HCRP n $\mathrm{n}^{\circ} 4981 / 2017$.

De acordo com Carta Circular $n^{\circ}$ 003/2011/CONEP/CNS, datada de 21/03/2011, o sujeito de pesquisa ou seu representante, quando for o caso, deverá rubricar todas as folhas do Termo de Consentimento Livre e Esclarecido TCLE - apondo sua assinatura na última do referido Termo; o pesquisador responsável deverá da mesma forma, rubricar todas as folhas do Termo de Consentimento Livre e Esclarecido - TCLE - apondo sua assinatura na última página do referido Termo.

Este Comite segue integralmente a Conferência Internacional de Harmonização de Boas Práticas Clínicas (IGH-GCP), bem como a Resolução no 466/12 CNS/MS. $\frac{\text { Parcial e o Relatório Final da pesquisa. }}{\text { Atenciosamente. }}$

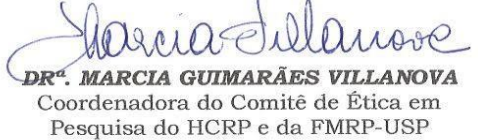

Ilustrissimos Senhores

CARLOS HENRIQUE MIRANDA

FRANCINE DE CASTRO ALVES VICTAL

Unidade de Emergência-HCFMRP-USP

HOSPITAL DAS CIINICAS DA FACULDADE DE MEDICINA DE RIBEIRÃO PRETO DA UNIVERSIDADE DE SÃO PAULO de Élica em Pesquisa do HCRP e FMRP-USP Campus Universitário - Monte Alegre
$14048-900$ Riberắo Preto SP 


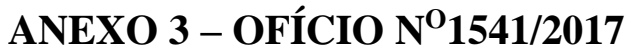

\section{Termómetros Emocionais}

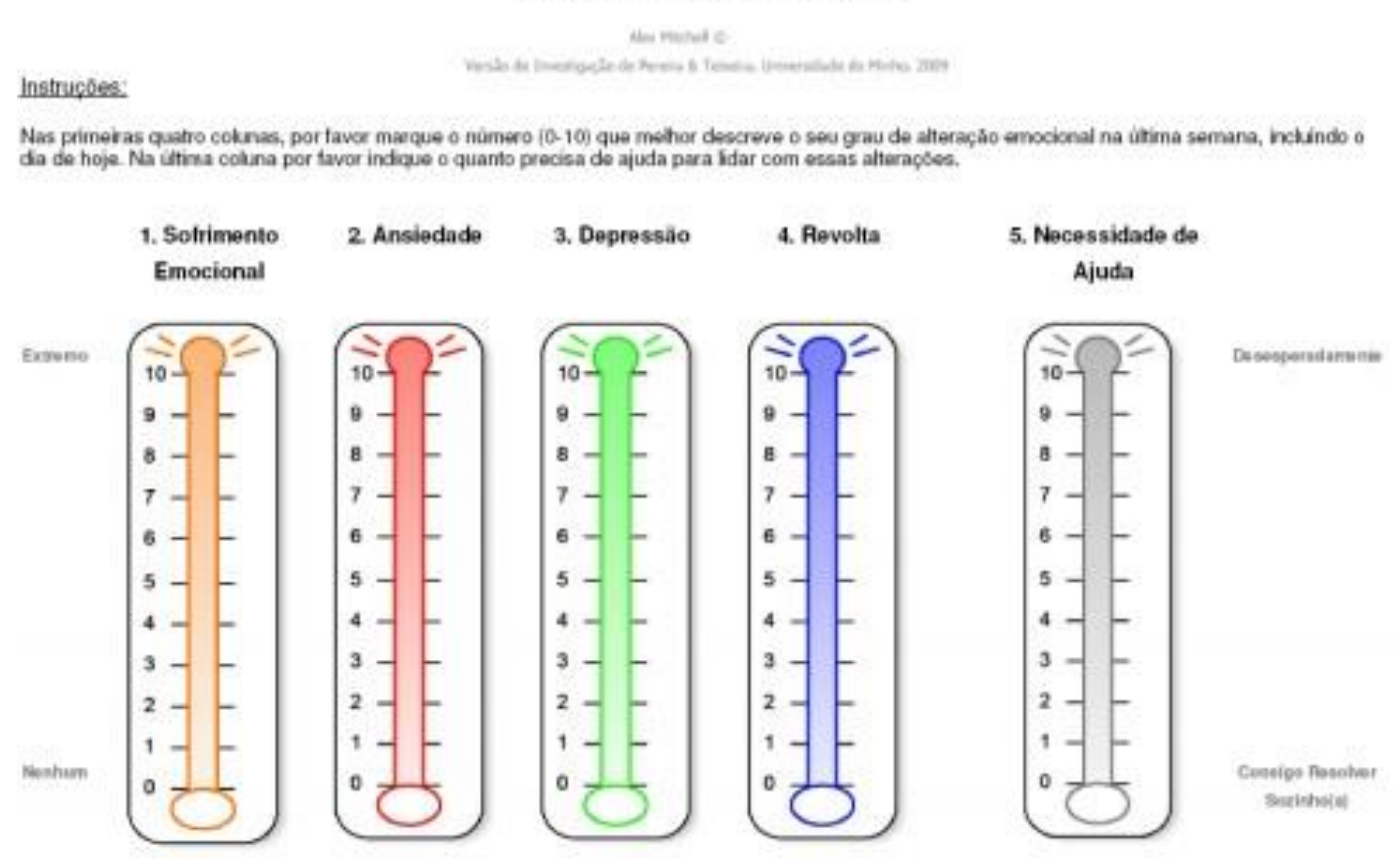

Disponivel em: $\underline{\text { http://www.psycho-oncology.info/ET.htm }}$ 


\section{ANEXO 4 - TERMÔMETRO EMOCIONAL PARTICIPANTES (ANTES E APÓS INTERVENÇÃO)}

\section{Termómetros Emocionais}

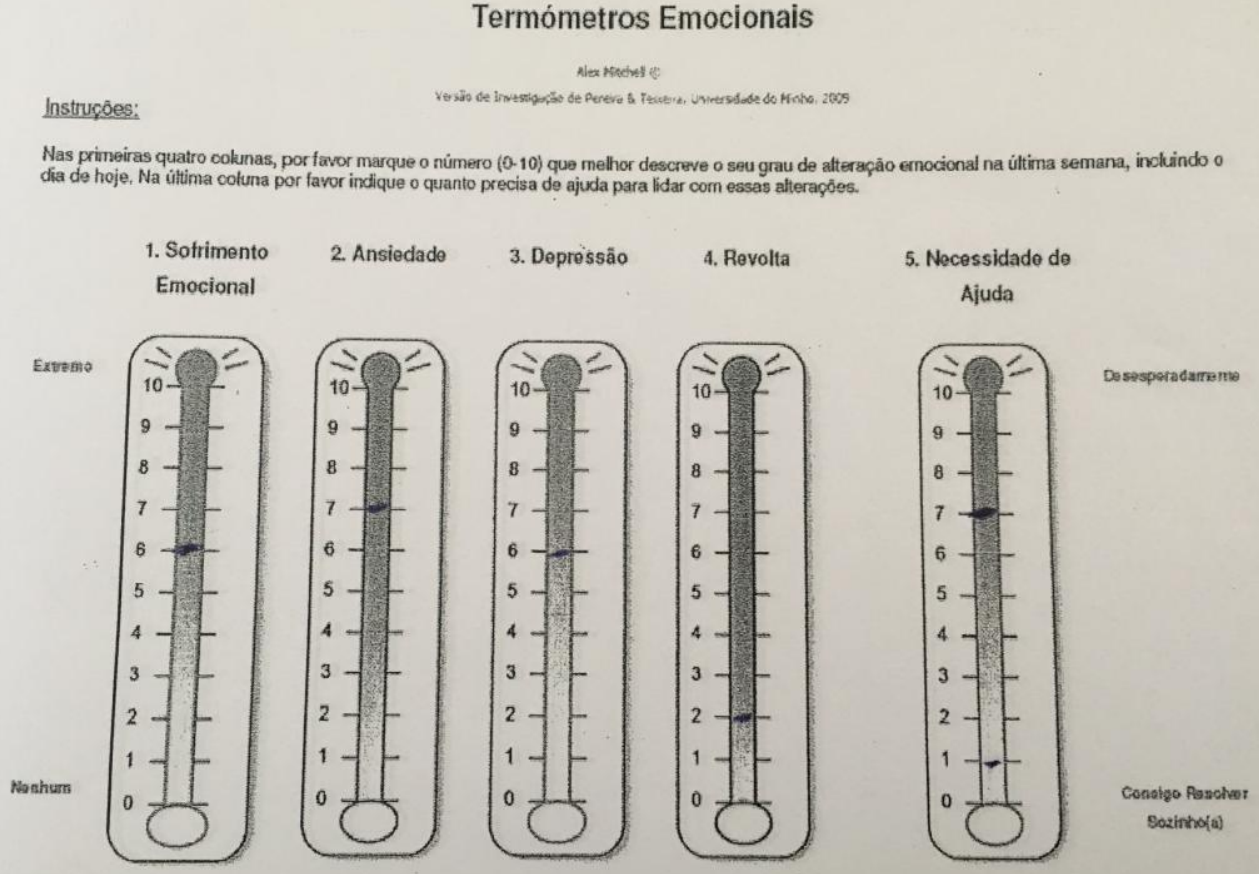

(2)

Termómetros Emocionais

Instrupoes:

Nien Badist e.

Nas primeiras quatro colknas, por favor marque o número (2-10) que melhor descreve a seu grau de atteraçâo emocional na úttima semana, inchindo o fia de heje. Na ütima coluna por favor incique o quanto precisa de ajuda para lidar corn essas alteraçbes.

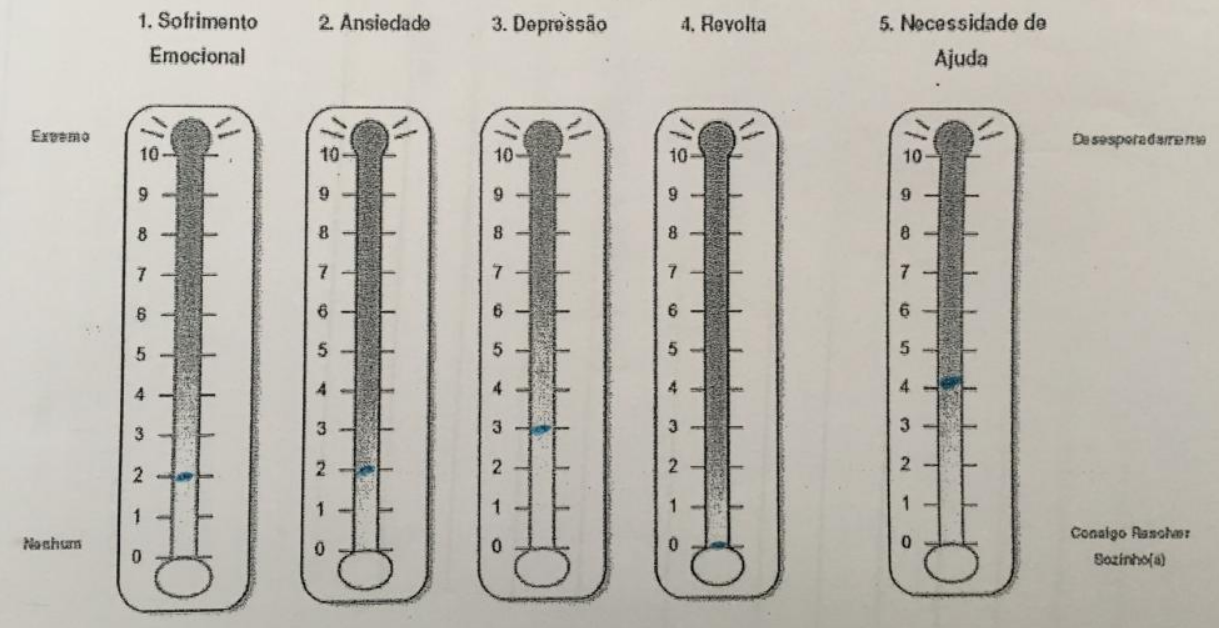

